\title{
NEDERLANDSE ELITES IN DE TWINTIGSTE EEUW Continuiteit en verandering
}

Meindert Fennema en Huibert Schiff (red.) 
Nederlandse elites in de twintigste eeuw 



\section{Nederlandse elites in de twintigste eeuw}

Continuïteit en verandering

Onder redactie van

Meindert Fennema

Huibert Schijf 
Nederlandse elites in de twintigste eeuw: continuïteit en verandering is de boekaflevering bij jaargang 78 (2003) van het sociologisch tijdschrift Mens \& Maatschappij.

Omslagfoto met dank aan Knip- en Naaiatelier Neeltje

Omslagontwerp: Jos Hendrix, Groningen

Vormgeving binnenwerk: PRografici, Goes

ISBN $905356649 \mathrm{X}$

NUR 756

\section{(C) Amsterdam University Press, Amsterdam 2004}

Alle rechten voorbehouden. Niets uit deze uitgave mag worden verveelvoudigd, opgeslagen in een geautomatiseerd gegevensbestand, of openbaar gemaakt, in enige vorm of op enige wijze, hetzij elektronisch, mechanisch, door fotokopieën, opnamen of enige andere manier, zonder voorafgaande schriftelijke toestemming van de uitgever.

Voorzover het maken van kopieën uit deze uitgave is toegestaan op grond van artikel 16B Auteurswet $1912 \mathrm{j}^{\mathrm{o}}$ het Besluit van 20 juni 1974, Stb. 351, zoals gewijzigd bij het Besluit van 23 augustus 1985, Stb. 471 en artikel 17 Auteurswet 1912, dient men de daarvoor wettelijk verschuldigde vergoedingen te voldoen aan de Stichting Reprorecht (Postbus 3051, 2130 кв Hoofddorp). Voor het overnemen van gedeelte(n) uit deze uitgave in bloemlezingen, readers en andere compilatiewerken (artikel 16 Auteurswet 1912) dient men zich tot de uitgever te wenden. 


\section{Inhoudsopgave}

Meindert Fennema en Huibert Schijf

Elites in Nederland

Joris Nobel en Meindert Fennema

Economische elites na de dekolonisatie van Nederlands-Indië:

verlies van posities, desintegratie van netwerken, verschuiving van zwaartepunten

Eelke Heemskerk

De internationalisering van de financieel-economische bestuurselite

Huibert Schijf, Jaap Dronkers en Jennifer R. van den Broeke-George

De overdracht van eliteposities binnen adellijke en patricische

families in de twintigste eeuw

Leny E. de Groot-van Leeuwen

Blijvend gezag: continuïteit en verandering in de rechterlijke macht

Jan C.C. Rupp, John Schuster en Huibert Schijf

Toetreding en terugdringing: de opkomst van een lokale politieke elite 101

Personalia 



\title{
Elites in Nederland
}

\author{
Meindert Fennema en Huibert Schijf
}

Politieke en economische elites hebben het tegenwoordig niet gemakkelijk in het publieke debat in Nederland: hun inkomens worden bekritiseerd, hun gezag wordt betwijfeld en aan de exclusiviteit van hun posities wordt geknaagd. De voor Nederland ongebruikelijk heftige maatschappelijke beroeringen in 2002 hebben de belangstelling voor en de kritiek op elites aanzienlijk doen toenemen. Dat politici in de media hun beleid verdedigen of proefballonnetjes oplaten zijn we gewend, maar het is opmerkelijk om te zien hoe vaak 'captains of industry' en bankiers tegenwoordig op de televisie tekst en uitleg van hun plannen, fusies en bedrijfssaneringen komen geven. Door de grote openheid is het in de moderne samenleving voor elites ook veel moeilijker om de dubbele moraal die Machiavelli voorschrijft, waarbij voor de vorst een ander normen- en waardenstelsel geldt dan voor zijn onderdanen, in stand te houden.

Schrijven over elites heeft vrijwel altijd een morele inslag. Schrijvers als Mosca en Pareto analyseerden aan het begin van de twintigste eeuw niet alleen de rol van elites in samenlevingen in het verleden en het toenmalige heden, maar ze hadden ook uitgesproken opvattingen over wat de taak van elites in de samenleving zou moeten zijn, zoals al veel eerder Machiavelli in zijn De vorst (1513) niet alleen het gedrag van de vorst beschreef, maar hem vooral voorschreef hoe zijn moreel gedrag eruit zou moeten zien (vgl. Fennema, 2003). Hoe staat het met de morele kwaliteit van de huidige elites? Daarover is het moeilijk een oordeel te geven. Weliswaar is er vooral de laatste tijd een reeks van grotere en kleinere schandalen aan het licht gekomen, maar bij gebrek aan vergelijking met vroeger tijden is een oordeel over het morele gehalte een hachelijke zaak. Wij mogen immers aannemen dat veel wat vroeger verborgen bleef thans in het schelle daglicht van de openbaarheid zichtbaar is geworden. Maar maatschappelijke kritiek en journalistieke aandacht worden niet altijd gevolgd door wetenschappelijk onderzoek naar het object van die kritiek en soms bestaat dat ook helemaal niet. 
Het is bijna twintig jaar geleden dat een boekaflevering van Mens en Maatschappij de Nederlandse elites tot onderwerp had. Het boekje was getiteld Nederlands elites in beeld (Dronkers \& Stokman, 1984) en leunde sterk op het onderzoek naar dubbelfuncties in het bedrijfsleven, zoals dat bekend was geworden door de publicatie van Graven naar Macht (Helmers e.a., 1975, zie ook Fennema \& Schijf, 1979). Enkele schrijvers van toen, Dronkers, Fennema en Schijf, publiceren ook in deze bundel en het is verheugend te zien dat ook nieuwe onderzoekers een bijdrage leveren, zoals er ook nieuwe onderwerpen en methoden van onderzoek aan de orde komen. Fennema en Schijf (1984) constateerden toen dat de belangstelling voor onderzoek naar elites door sociaalwetenschappers beperkt was in Nederland. De vraag is of het nu veel anders is. We zullen niet een nieuw overzicht geven - de afzonderlijke bijdragen bevatten veel relevante en recente literatuurverwijzingen - maar we willen volstaan met de constatering dat historisch onderzoek naar elites, net als in 1984, in ruimere mate wordt gepubliceerd dan sociaal-wetenschappelijk onderzoek naar de huidige elites. Wel zijn er in navolging van Graven naar Macht enkele internationale vergelijkingen gepubliceerd, zoals Networks of corporate power (Stokman e.a., 1985) en een studie van de Duitse socioloog Windolf (2002). Beide publicaties vergelijken de netwerken van dubbelfunctie in het bedrijfsleven voor diverse Europese landen en de Verenigde Staten. Windolf besteedt bovendien aandacht aan elitenetwerken en de opleiding en carrière van de 'big linkers'. In de meeste ons omringende landen is bij politicologen of sociologen onderzoek naar elites echter geen hoofdthema en dat geldt eveneens voor de Verenigde Staten. Niettemin zijn bijvoorbeeld in Duitsland en Denemarken opmerkelijke studies over elites verschenen die met enige aanpassingen ook in Nederland zouden kunnen worden uitgevoerd.

Door de Universiteit van Mannheim zijn in 1968 en 1981 omvangrijke studies verricht naar elites in een breed scala van maatschappelijke sectoren. De sector politiek en bestuur viel daar uiteraard onder, maar ook elites uit cultuur, economie, massamedia en de kerk werden onderzocht. Het meest recente onderzoek in deze reeks is in 1995 uitgevoerd door een onderzoeksgroep aan de Universiteit van Potsdam. De steekproef in 1995 heeft een omvang van 1082 bekleders van de diverse eliteposities. Bij alle drie de projecten zijn personen uitvoerig ondervraagd over uiteenlopende onderwerpen, waaronder hun opleiding en familieachtergrond (Bürklin e.a., 1997: 35-69). In het onderzoek uit 1995 bestaat vooral grote aandacht voor de vraag in hoeverre de elites uit de neue Bundesländer zijn geïntegreerd met de lokale en nationale elites uit het vroegere West-Duitsland. Dit Duitse voorbeeld laat zien dat zo'n onderzoek heel goed uitvoerbaar zou zijn - hoewel kostbaar om te financieren - en een schat aan gegevens zou opleveren, zoals uit de omvangrijke publicatie blijkt. Het zou jonge onderzoekers voor jaren materiaal voor hun proefschrift bieden. Een andere Duitse studie die de moeite waard is om genoemd te worden, is die van Hartmann (2002) naar het verband tussen sociale afkomst en een topcarrière in de economie, politiek, justitie en 
wetenschap. Beide publicaties laten zien dat sociologische studies naar elites in het buitenland bestaan en tot maatschappelijk relevante inzichten kunnen leiden (zie voor enkele Franse voorbeelden het artikel van Schijf en anderen in deze bundel). In Denemarken is onlangs een zeer grootschalig eliteonderzoek afgesloten dat in opdracht van de regering door zo'n vijftig onderzoekers is uitgevoerd (Christiansen e.a., 2001).

\section{Horizontale en verticale integratie}

Bij onderzoek naar elites staat meestal een van de volgende twee vragen centraal. De eerste richt zich op horizontale integratie: de mate waarin elites onderling met elkaar zijn verbonden en onderling samenwerken (vgl. Bürklin e.a., 1997: 13). Uiteindelijk komt deze vraag neer op de klassieke tegenstelling tussen elites als een homogene groep en elites die in onderlinge concurrentie zijn verwikkeld. Horizontale integratie kent verscheidene aspecten. Zo heeft Lijphart (1968) in zijn beroemde studie naar de verzuiling erop gewezen dat de Nederlandse samenleving in de jaren vijftig en zestig weliswaar sterk verzuild was, maar dat de politieke en bestuurlijke elites uit de diverse zuilen een grote mate van onderlinge samenwerking kenden. Dat was volgens hem een belangrijke reden waarom Nederland, ondanks de grote religieuze en ideologische scheidslijnen in die tijd, een zeer stabiele samenleving kende.

Een ander voorbeeld van horizontale integratie is het verschijnsel van pantouflage in Frankrijk: de overstap van leden uit de bestuurlijke elites naar topposities in het bedrijfsleven, of omgekeerd (Charle, 1987). De aanwezigheid van dubbelfuncties in het bedrijfsleven, of tussen bedrijfsleven en overheid, is een andere vorm van horizontale integratie die wijst op een zekere mate van homogeniteit binnen de financieel-economische elite. Zie bijvoorbeeld Graven naar Macht (1975), waar ook aandacht wordt besteed aan de personele relaties tussen bedrijfsleven en overheid. Recent onderzoek naar de maatschappelijke achtergronden van directeuren in het bedrijfsleven bestaat niet, maar Beekenkamp (2002) biedt inzicht in de achtergronden van president-directeuren in 1975. Een minderheid stamde toen nog uit de economische elite, maar voor de meerderheid gold dat niet.

De vraag naar horizontale integratie kan ook worden benaderd vanuit de gemeenschappelijke achtergronden van leden uit de bestuurlijke elites. De basisveronderstelling hierbij is dat personen die gemeenschappelijke achtergronden hebben, zoals opleiding, sociaal milieu, religie of gender, of dezelfde ervaringen in hun loopbaan hebben opgedaan, ook goed kunnen samenwerken en in bepaalde mate een homogene groep vormen (vgl. Secker, 1995).

De tweede vraag betreft de verticale integratie, dat wil zeggen de vraag of bepaalde maatschappelijke groepen onder- of oververtegenwoordigd zijn in de beschikbare eliteposities. In Nederland is die vraag bijvoorbeeld terug te vinden in het werk van Secker over politieke elites $(1991 ; 1995)$. Deze verticale integratie 
en loyaliteit is in het huidige Nederland sterk aan erosie onderhevig, met als gevolg dat de horizontale loyaliteiten de verticale overheersen. Elites hebben zich altijd meer thuis gevoeld met hun 'eigen soort mensen' dan met lager geplaatsten. Het grootste probleem van de huidige democratie is het gebrek aan verticale loyaliteiten bij een groot deel van de burgers, waardoor de politieke elites het contact met hun achterban hebben verloren. Waar die verticale loyaliteit nog wel bestaat levert dat problemen op, zoals Rupp en anderen in hun artikel in deze bundel laten zien.

\section{Methoden van onderzoek}

De elites die in deze bundel worden beschreven zijn gedefinieerd op grond van posities die door hen worden bekleed: directeuren, rechters of gemeenteraadsleden. Bij adel en patriciaat gaat het om personen die als zodanig staan geregistreerd. Het selecteren op grond van posities is een gebruikelijke manier om elites af te bakenen bij politicologisch of sociologisch onderzoek, waar de aandacht vaak gericht is op bepaalde kenmerken en achtergronden van deze bekleders. Het algemeen taalgebruik is meestal breder. Zo zal er sprake zijn van iemand uit de sportelite, terwijl ook de 'bekende Nederlander' soms gezien zal worden als iemand die tot een elite behoort (maar welke?), hoe kortstondig die roem ook is. Deze onderwerpen komen in deze bundel niet aan de orde, enerzijds omdat zulk gebruik van het woord 'elite' heel snel tot inflatie en lege termen leidt, anderzijds omdat er misschien wel veel over gepraat wordt maar we geen systematisch onderzoek naar zulke fenomenen kennen. Dat geen artikel over bijvoorbeeld wetenschappelijke of culturele elites is opgenomen ervaren we als een gemis, maar ook hier ontbreekt onderzoek. Wel is het zo dat de aandacht voor elites niet alleen op herkomst, macht of status is gericht. Langzamerhand komt er ook enige aandacht voor andere aspecten van elites, zoals hun manier van wonen (De Wijs-Mulkens, 1999).

De methoden van onderzoek die hier gebruikt zijn, zijn zeer gevarieerd: interviews, bestaand biografisch materiaal en klassieke netwerkanalyse. Betrekkelijk veel gegevens over elites zijn openbaar want zo verborgen leven elites nu ook weer niet, hoewel het handelen van economische elites minder openbaar is dan dat van politieke of bestuurlijke. Het vereist tijd en geduld, speurzin en creativiteit, maar onmogelijk is het niet, hoewel uitgebreide interviews of enquêtes dikwijls zullen worden geweigerd. De methode gebruikt in het artikel over adel en patriciaat sluit goed aan bij die van Hartmann. Daarvoor onderzocht hij de herkomst van 6500 ingenieurs, juristen en economen, afgestudeerd in de jaren 1955, 1965, 1975 en 1985, waarbij hij kon gebruikmaken van een unieke soort gegevens, namelijk de biografische gegevens die in die periode in een dissertatie verplicht moesten worden opgenomen. Op basis van deze gegevens ging hij na wie later een elitepositie heeft bereikt - een enorm werk overigens. Summier geformuleerd komt zijn conclusie erop neer dat weliswaar het Duitse onderwijs- 
systeem veel opener is geworden, maar dat houdt niet in dat de toegang tot de elites daarmee opener is geworden.

Bij onderzoek naar sociale mobiliteit is inmiddels het idee ingeburgerd dat gegevens uit de vroegere onderwijsloopbaan van groot belang zijn. Zulke zaken komen in enquêtes uitvoerig aan de orde met behulp van retrospectieve vragen waarbij de achtergrond van de ouders wordt geconstrueerd. Bij onderzoek naar de kans om een elitepositie te bereiken, en daarmee naar de openheid van een samenleving, heeft deze procedure grote nadelen. Er wordt immers meestal begonnen met het kiezen van een elite waarover dan gegevens worden verzameld. Maar deze personen op eliteposities hebben deze posten al bereikt, zodat we nog geen inzicht hebben in hoe groot de kans is om een elitepositie te bereiken. Het bijzondere van de aanpak van Hartmann is dat hij een steekproef aan het begin neemt, namelijk bij het voltooien van een proefschrift, en dan kijkt wie van hen later een elitepositie heeft bereikt. Een vergelijkbare procedure is toegepast in het artikel over adel en patriciaat (zie ook Dronkers e.a., 1996, waar steekproeven van ingeschreven studenten over een reeks van decennia worden gebruikt).

\section{De bijdragen}

Alle artikelen richten zich bij hun beschrijving van een specifieke elite, rechters, adel of patriciaat, op ontwikkeling door de tijd. Soms over enkele decennia, soms over een hele eeuw. De eerste twee artikelen zijn gewijd aan de economische elite en hun internationaal opererende bedrijven. Nobel en Fennema schrijven over het bedrijfsleven betrokken bij Nederlands-Indië en Indonesië. Hun werk sluit nauw aan op analyses van dubbelfuncties, zoals die met Graven naar Macht zijn geïntroduceerd. Ze laten zien hoe de belangen van het Nederlandse bedrijfsleven ook in het onafhankelijke Indonesië nog lang bleven gehandhaafd. Ook in deze periode was het bedrijfsleven sterk international gericht, maar voor een niet geringe sector betrof dat vooral de banden met de vroegere kolonie. Inmiddels domineren termen als 'internationalisering' en 'globalisering' het politicologische en economische discours. Heemskerk schrijft over de huidige internationalisering van de financieel-economische elite in Nederland. Er blijkt een aanzienlijke toename in het aantal buitenlandse bestuurders te zijn, maar slechts een zeer beperkt aantal is extern gerekruteerd. In combinatie beschrijven de artikelen van Nobel en Fennema en Heemskerk een eeuw van internationalisering binnen het Nederlandse bedrijfsleven.

De volgende twee artikelen gaan over afzonderlijke groepen: adel, patriciaat en rechters. De adel en het patriciaat zijn officieel geregistreerde families uit de maatschappelijke bovenlaag. Maar terwijl opname in het Nederland's Adelsboek gebaseerd is op een overgeërfde kwaliteit, namelijk lid zijn van een adellijke familie, is opname in het Nederlands's Patriciaat gebaseerd op bestuurlijke kwaliteiten over enkele generaties. Over adel hebben vooral genealogen en oprechte 
amateurs geschreven in meestal fraai geïllustreerde boeken (een uitzondering is de historische studie van Kuiper, 1993). Zulke publicaties hebben hun eigen waarde, maar de sociologische onderzoeksvraag of een adellijke titel een bijdrage levert bij het verwerven van een elitepositie is pas van recente datum (Dronkers, 200o). In vergelijking met het patriciaat heeft een adellijke titel nog een voordeel bij het verwerven van een elitepositie, zo blijkt. Het artikel van De Groot-van Leeuwen analyseert de continuïteit en verandering in de rechterlijke macht in de afgelopen decennia. Ze vraagt zich af in hoeverre rechters een gezagselite vormen. Daarbij maakt ze ook een vergelijking tussen rechters en advocaten. De schrijfster ziet de rechters als een gezagselite, gebaseerd op meritocratische selectie.

Dat er een artikel over allochtone gemeenteraadsleden in een bundel over Nederlandse elites is opgenomen wekt misschien verbazing. Maar terwijl het politieke debat steeds meer draait om de vraag of de integratie van diverse migrantengroepen mislukt is, zijn er in de maatschappij vele voorbeelden te vinden van het slagen of gestaag doorlopen van dit integratieproces. Dat allochtonen participeren in gemeenteraden, is zo'n bewijs van het tegendeel, hoewel dat niet wil zeggen dat dit proces geheel probleemloos verloopt. Langzamerhand ontstaat een lokale politieke elite met een allochtone achtergrond. Het artikel van Rupp, Schuster en Schijf vergelijkt de achtergronden van autochtone en allochtone raadsleden in de vier grootste steden en plaatst deze ontwikkelingen in het langetermijnperspectief van een steeds veranderende samenstelling van gemeenteraden.

Of de artikelen in deze bundel een morele inslag hebben laten we aan het oordeel van de lezer over. Als redacteuren menen we dat de artikelen in ieder geval zijn geïnspireerd door actuele kwesties in onze samenleving, maar dat ze ook de grote stabiliteit van sommige Nederlandse elites laten zien.

Tot slot willen we Annerienke Fioole bedanken voor haar grote hulp bij het redigeren van de teksten.

\section{Literatuur}

Beekenkamp, G.G. (2002). President-directeuren, posities en patronen. Een studie naar de rekrutering van de leiders van de 250 grootste ondernemingen in Nederland. Amsterdam: Aksant.

Bürklin, W., Rebendorf, H., u.a. (1997). Eliten in Deutschland. Opladen: 1997.

Charle, Chr. (1987). Le pantouflage en France (vers 1880-vers 1980). Annales ESC, $42,1115-1137$.

Christiansen, P.M., Moller, B., e.a. (2001). Den Danske elite. Copenhagen: Hans Reitzels Vorlag.

Dronkers, J. \& Stokman, F.N. (1984). Nederlandse elites in beeld. Rekrutering, samenhang en verandering. Deventer: Van Lochum Slaterus. 
Dronkers, J., Schijf, H., van Wolput, B. \& Rupp, J.C.C. (1996). A university degree as gateway to the Dutch political and administrative elites from 1815 to 1960. Netherlands' Journal of Social Sciences, 32, 81-89.

Dronkers, J. (2000). De maatschappelijke relevantie van hedendaagse Nederlandse adel. Amsterdams Sociologisch Tijdschrift, 27, 233-268. Een Engelse versie is gepubliceerd in European Sociological Review (2003), 19, 81-99.

Fennema, M. \& Schijf, H. (1979). Analysing interlocking directorates. Social Networks, 1, 297-332.

Fennema, M. \& Schijf, H. (1984). Netwerkonderzoek onder Nederlandse elites. In J. Dronkers \& F.N. Stokman (1984). Nederlandse elites in beeld. Rekrutering, samenhang en verandering (pp. 9-27). Deventer: Van Lochum Slaterus.

Fennema, M. (2003). Over de kwaliteit van politieke elites. De Gids, 167, 790-80o.

Hartmann, M. (2002). Der Mythos von den Leistungseliten. Spitzenkarrieren und soziale Herkunft in Wirtschaft, Politik, Justiz und Wissenschaft. Frankfurt: Campus.

Helmers, H.M., Mokken, R.J., Plijter, R.C. \& Stokman, F.N. (1975). Graven naar Macht. Op zoek naar de kern van de Nederlandse economie. Amsterdam: Van Gennep.

Kuiper, Y. (1993). Adel in Friesland 1780-1880. Groningen: Wolters-Noordhoff/ Egbert Forsten.

Lijphart, A. (1968). The politics of accommodation: pluralism and democracy in the Netherlands. Berkeley: University of California Press.

Secker, W.P. (1991). Ministers in Beeld. De sociale en functionele herkomst van de Nederlandse Ministers. (1848-1990). Leiden: DSWO Press.

Secker, W.P. (1995). Political administrative elites in The Netherlands: profiles and perceptions. Historical Social Research, 20, 61-87.

Stokman, F.N., Ziegler, R. \& Scott, J. (1985). Networks of corporate power. Cambridge: Polity Press.

Wijs-Mullekens, E. de (1999). Wonen op stand. Lifestyles en landschappen van de culturele en economische elite. Amsterdam: Het Spinhuis.

Windolf, P. (2002). Corporate networks in Europe and the United States. Oxford: Oxford University Press. 



\title{
Economische elites na de dekolonisatie van Nederlands-Indië \\ Verlies van posities, desintegratie van netwerken, verschuiving van zwaartepunten
}

\author{
Joris Nobel en Meindert Fennema ${ }^{1}$
}

\section{Inleiding}

Het Nederlands belang bij Indië is voor de jaren vóór de Tweede Wereldoorlog tamelijk exact becijferd. De latere Nobelprijswinnaar Tinbergen en zijn toenmalige CBScollega Derksen (1945) kwamen uit op een belang van 13,7 procent van het Nationaal Inkomen van Nederland in 1938 (zonder secundaire effecten 7,9\%). Maar ook anderszins was het belang van Indië voor politiek en bedrijfsleven in Nederland destijds onmiskenbaar. Men hoeft slechts te denken aan de carrière van politici en ondernemers als Colijn en Deterding, ${ }^{2}$ of aan de oorsprong van de toentertijd grootste handelsbank, de Nederlandsche Handelmaatschappij (NHM), om eraan herinnerd te worden. Geen wonder dat het gezegde 'Indië verloren, rampspoed geboren' opgeld deed. Indië was een van de kurken waarop de Nederlandse economie dreef. Zonder koloniën dreigde Nederland te worden teruggeworpen tot de rang van Denemarken, een vriendelijke agrarische natie zonder enige internationale allure of ambitie.

Toch geschiedde na de oorlog anders. De Duitse bezetting betekende een kaalslag voor de Nederlandse economie. En de Japanse bezetting bleek de opmaat voor de onafhankelijkheid van Indonesië, na een laatste, desperate Nederlandse poging om de koloniale verhoudingen in stand te houden. Vervolgens echter vormde de industrialisatie van de jaren vijftig, gestimuleerd door de Marshallhulp, voor Nederland de aanzet voor een periode van ongekende economische groei. En in plaats van de gevreesde rampspoed kwam er in Nederland uiteindelijk welvaart voor velen.

In dit artikel belichten we de veranderende structuur en oriëntatie van de Nederlandse economische elite in de tijd van dekolonisatie na de oorlog. Het Nederlands belang bij Indië werd gereduceerd tot nul. Maar wat betekende dat voor de samenstelling en opstelling van de economische elite, die aanvankelijk zo nauw verbonden was met ons Indië? Hoe veranderde daardoor haar structuur? Wat zegt dat over de heroriëntatie van het bedrijfsleven?

We analyseren de structuur van het netwerk van dubbelfuncties tussen Neder- 
landse op Indië georiënteerde bedrijven, en de ontwikkelingen daarin tussen 1945 en 1963. De analyse bouwt voort op Baudet en Fennema (1983). Door onze onderzoeksperiode vullen we de leemte tussen de studies over de periode rond 1900 en die over de jaren zestig en daarna.

In de volgende paragraaf schetsen we in meer detail het specifieke belang van Indië voor Nederland in het Interbellum. Kort ook schetsen we het gefaseerde verloop van de beëindiging van deze relatie na de oorlog. Deze informatie vormt de achtergrond waartegen onze gegevensverzameling en analyse in de loop van onze onderzoeksperiode bezien moeten worden.

Daarna beschrijven we de gegevensverzameling zelf, die betrekking heeft op 141 bedrijven en de daaraan verbonden directeuren en commissarissen. Voor deze gegevensverzameling presenteren we enkele kengetallen, ter vergelijking met eerdere en latere periodes volgens de hierboven genoemde studies. De daaropvolgende analyse richten we op de herstructurering van het Nederlandse op Indië georiënteerde bedrijfsleven in zijn verschillende geledingen.

In de slotparagraaf vatten we onze conclusies samen, en plaatsen we die in een breder perspectief.

\section{Nederland en Ind(ones)ië}

\section{Het belang van Indië voor Nederland}

De pessimistische verwachtingen uit de eerste alinea werden geschraagd door de feitelijke economische verhoudingen in het Interbellum. De omvang van de Nederlandse investeringen in Indië in 1938 was geschat op een bedrag van ongeveer 4 miljard gulden, bij een gelijktijdig nationaal vermogen van 20 à 25 miljard. Met andere woorden, ongeveer 15 à 20 procent van het Nederlands vermogen was in Indië geïnvesteerd. Daarmee had Nederland in Indië tweemaal zoveel belegd als in de Verenigde Staten en viermaal zoveel als in Duitsland. Een sterke toeneming in de eerste helft van de twintigste eeuw van het in Indië belegde Nederlandse kapitaal stond tegenover een vermindering van de directe handel tussen Nederland en Indië.

Voor ongeveer 1 miljard gulden hadden de Nederlandse beleggingen in Indië betrekking op de staatsschuld. Die was daarmee grotendeels in handen van Nederlandse beleggers. Een schatting van de verdeling van de overige investeringen over de verschillende bedrijfstakken in Indië is weergegeven in tabel 1, ontleend aan Derksen (1946). Daarbij zij opgemerkt dat het buitenland vooral investeerde in de moderne cultures en industrieën. Zo werkte de traditionele suikerindustrie voor bijna 100 procent met Nederlands kapitaal en de meer moderne rubberindustrie voor niet meer dan ongeveer 50 procent.

Van de dividenden en winsten die vanuit Indië naar het buitenland werden overgemaakt, kwam, zo neemt men aan, ongeveer 70 procent aan Nederland ten goede. Nederland blijkt in 1937 en 1938 jaarlijks voor zo'n 200 miljoen gulden aan dergelijke betalingen uit Indië ontvangen te hebben. Zoals in de negentiende eeuw de 
Tabel 1: De Nederlandse beleggingen in Indië per bedrijfstak, ca. 1938, in miljoenen guldens

\begin{tabular}{ll} 
Petroleum & 500 \\
Spoor- en tramwegen & 400 \\
Suiker & 400 \\
Rubber & 300 \\
Tabak & 150 \\
Thee & 100 \\
Oliepalm & 100 \\
Scheepvaart & 100 \\
Openbare nutsbedrijven & 100 \\
Overige cultures & 200 \\
Overige mijnbouw & 100 \\
Overige bedrijfstakken & 400 \\
& \\
Totaal & 2850 \\
\hline
\end{tabular}

nieuwe Nederlandse infrastructuur goeddeels werd gefinancierd vanuit het 'batig slot', zo werd in het Interbellum het structurele uitvoeroverschot van Indië gebruikt om het structurele (dollar)tekort van Nederland te kunnen bekostigen. Andere inkomsten ontstonden uit het scheepvaartverkeer met Indië, de uitvoer van Nederlandse (eind)fabrikaten zoals de Twentse katoentjes, de internationale handel in koloniale producten in Amsterdam, en dergelijke. Broek (1942) verwoordde het Nederlands belang bij Indië als volgt: 'Economically, the Netherlands has a double interest in the Indies: it is the investor of large amounts of capital and one of the Islands' most important suppliers of manufactured goods.'

Het samenvattend kwantitatief oordeel over de economische betekenis van Indië voor Nederland is hierboven al aangehaald. Derksen en Tinbergen (1941) becijferden de bijdrage van Indië aan het Nationaal Inkomen van Nederland in 1938 op maar liefst 13,7 procent, een bijdrage die bij een plotseling en totaal verlies van Indië voor Nederland geheel zou ophouden te bestaan. Zo ver is het om verschillende redenen echter niet gekomen.

- Het verlies is niet zo plotseling en totaal geweest.

- Diverse koloniale ondernemers hebben de dekolonisatie niet gelaten over zich heen laten komen.

- In Nederland zelf is de economie in de jaren vijftig ingrijpend en snel veranderd, mede door de Marshallhulp.

De eerste twee redenen werken we kort uit. 

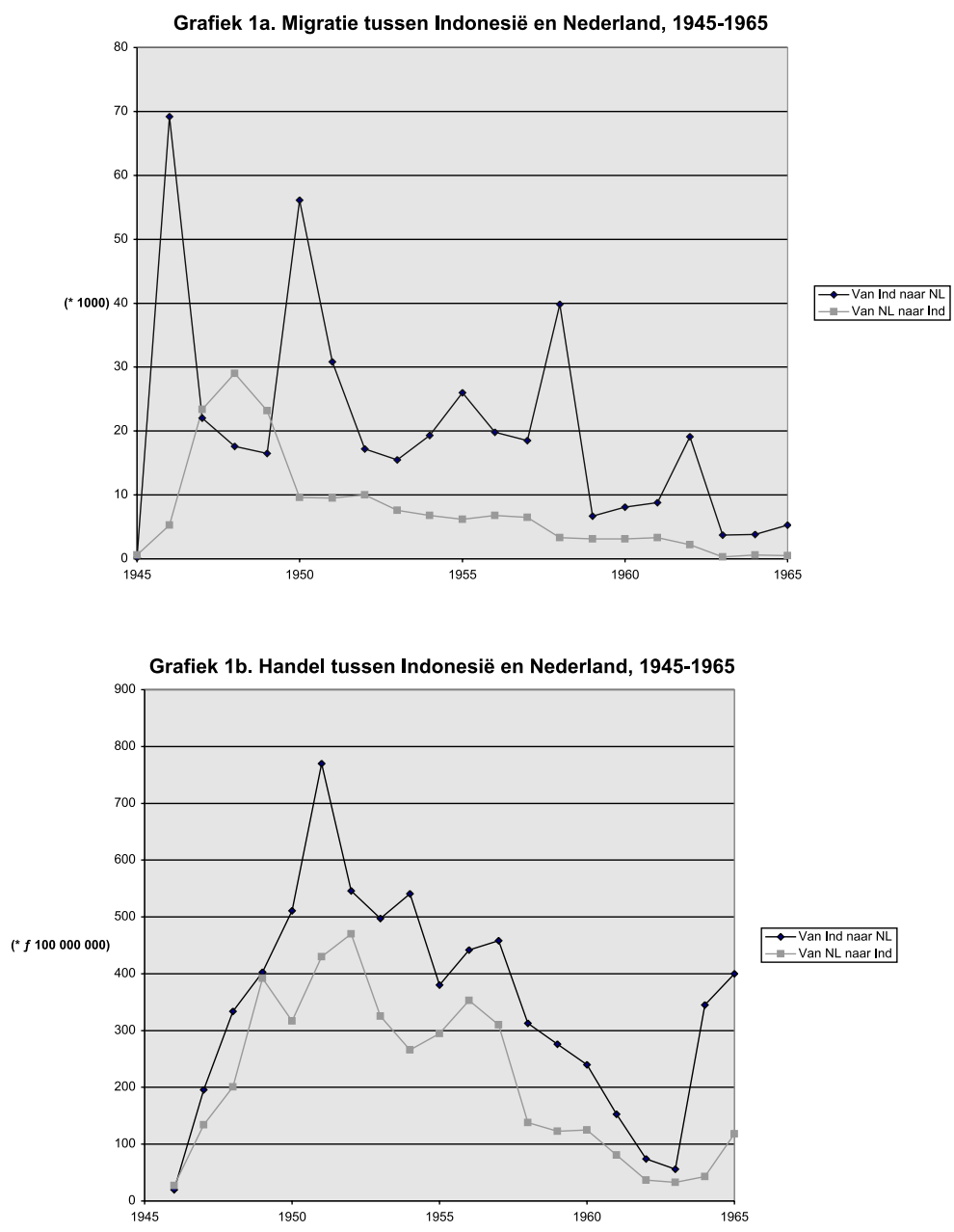

\section{De dekolonisatie}

Onze onderzoeksperiode laten we beginnen met de capitulatie van de Japanse bezetter in Indië in 1945 en eindigen met de overdracht van de Nederlandse soevereiniteit over Nieuw-Guinea aan Indonesië in 1963. In die periode van achttien jaar doen zich twee belangrijke cesuren voor. Ze worden geilllustreerd met grafiek 1, die het verloop van de handel en de migratie tussen Indonesië en Nederland weergeeft.

Op 27 december 1949 tekende de jonge koningin Juliana de soevereiniteitsoverdracht over de Indische archipel. Vanaf dat moment werd het bestaansrecht van de nieuwe Republiek der Verenigde Staten van Indonesië ook door de oude koloniale overheerser erkend. Maar de Nederlanders bleven nog alom aanwezig in de Nederlandse economie. Wel werden tal van bedrijfsnamen met verwijzingen naar de oude koloniale verhoudingen aan de nieuwe tijd aangepast. Zo ging de Koloniale Bank Cultuurbank heten, werd de Deli-Batavia Maatschappij de Deli-Djakarta Maatschappij en veranderde de Nederlandsch-Indische Gas- en Elektriciteitsmaatschappij haar 
naam in Overzeese Gas- en Elektriciteitsmaatschappij (OGEM). De nieuwe Indonesische overheid voerde loyaal de afspraken ter bescherming van Nederlands 'aanzienlijke financiële en economische belangen' uit, overeenkomstig artikel 20 van de financieel-economische overeenkomst behorende bij de Ronde Tafel Conferentie uit 1949. Tot in 1956 werden er door boeren bezette cultuurgronden ontruimd door de Indonesische overheid ten behoeve van Nederlandse ondernemingen als de Deli Maatschappij. Nog in 1957 waren Nederlandse bedrijven goed voor een belangrijk deel van de Indonesische export. Drie van de belangrijkste particuliere handelsbanken waren in Nederlandse handen. En ook voor het interinsulaire verkeer was Indonesië nog steeds afhankelijk van de Nederlandse Koninklijke Paketvaart Maatschappij (KPM). Dat neemt niet weg dat de Indonesische overheid wel degelijk meer greep op strategische bedrijfstakken trachtte te krijgen. Daarbij valt te denken aan de openbare nutsbedrijven zoals de gas- en elektriciteitsmaatschappijen, verder het verkeer (de spoor- en tramwegmaatschappijen, scheep- en luchtvaart) en de banken.

Begrijpelijkerwijze verslechterden de verhoudingen. De onafhankelijkheid en de Korea-hausse brachten Indonesië niet de gehoopte welvaart. En Nederlands economische aanwezigheid in Indonesië maar ook zijn soevereiniteit over Nieuw-Guinea was de Indonesiërs in toenemende mate een doorn in het oog. Eind oktober 1957 kwam een vierdaagse anti-Nederlandse boycot op gang, op instigatie van het Indonesische kabinet. En ruim een maand later bezetten Indonesische arbeiders de kantoren van de KPM, symbool bij uitstek van het kolonialisme, vervolgens ook andere Nederlandse bedrijven. De bezette bedrijven werden al snel onder toezicht van de Indonesische overheid geplaatst, die ook het beheer over alle Nederlandse cultuurmaatschappijen overnam. Deze laatste maatregel werd later uitgebreid tot alle als Nederlands aangemerkte bedrijven. De onteigeningen betroffen 500 à 600 Nederlandse bedrijven. In ruim een half jaar tijd werden 36.000 Nederlanders gerepatrieerd. De Shell en Unilever wisten overigens nationalisatie te ontlopen door hun half Engelse herkomst. De Shell verving haar Nederlandse personeel door Engelse werknemers uit Iran over te brengen. De Indonesische overheid trof overigens ook andere strafmaatregelen tegen Nederland. De thee- en tabakmarkten in Europa werden verplaatst van Amsterdam naar respectievelijk Antwerpen en Bremen. En Nederlandse schepen werd het ronduit verboden in Indonesische havens te verschijnen.

Voor 'Nederland in Indië' kwam dit alles onverwacht, aldus Baudet (1983: 136): Pearl Harbor, de capitulatie en Japanse interneringskampen, de bevrijding en daaropvolgende lancering van de Republiek Indonesië, de Amerikaanse ideeën over de vrijmaking der koloniën. Er was veel schade voor het bedrijfsleven, niet in het minst doordat het soms tot driemaal toe met de tactiek der verschroeide aarde was geconfronteerd. Direct na de beëindiging van de Tweede Wereldoorlog richtten de ondernemers zich dan ook allereerst op de wederopbouw van hun bedrijven. Ze gingen er automatisch van uit dat het Nederlandse gezag hersteld en gehandhaafd zou worden. Herstel en garantie van de rechtszekerheid was voor hen het allereerste belang. Men drong zelfs aan op zuiveringsacties in republikeins gebied en ontwapening van 
republikeinse benden, zoals bijvoorbeeld Bolderhey van de HVA ten overstaan van gouverneur-generaal Van Mook. Na het echec van de eerste militaire ('politionele') actie - niet voor niets droeg deze de codenaam 'Product' - bekenden zij zich echter snel en in toenemende mate tot een veel zakelijker realisme.

Men evolueerde naar een aanvaarding van het onafhankelijk Indonesië, in het besef land en volk beter te kennen dan wie ook. Zo stelde de Deli Maatschappij in haar jaarverslag over 1949 dat de veiligheid in Deli sedert de soevereiniteitsoverdracht sterk verbeterd was. De Bandar Rubbermaatschappij besefte al in 1949 terdege gast te zijn geworden in een vreemd land, aldus oud-directeur Jacobs (Baudet, 1983: 154). De Nederlandse hoofdkantoren en vooral de Nederlandse politiek volgden deze omslag slechts op de nodige afstand. En in de jaren vijftig verslechterde het politieke klimaat snel naarmate de daden en redevoeringen van president Soekarno agressiever werden. Hoewel men het Nieuw-Guinea-beleid van de Nederlandse overheid veroordeelde, steunden slechts weinigen de lobby van de groep Rijkens die de Nederlandse regering ertoe wilde bewegen West Irian over te dragen aan Indonesië.

Toch zijn koloniale ondernemers in deze veranderende omstandigheden elders gelegenheden voor investeringen dan wel export gaan zoeken. Het aantal bedrijven dat dit met succes gedaan heeft, is echter niet zo groot. Het waren volgens Brand (1963) en Gorter (1964) overwegend grotere bedrijven, die hun productie al eerder gediversifieerd en hun belangen al eerder geografisch gespreid hadden. Het spreekt vanzelf dat het voor de cultuur-, en voor de spoor- en tramwegmaatschappijen minder eenvoudig was dan voor meer mobiele sectoren als handel, scheepvaart en bankwezen.

Een in dit verband interessante observatie komt van Smit (1963). Na de naasting van haar elektriciteitsbedrijven in en om Djakarta in 1954, benoemde de OGEM nieuwe commissarissen in het bijzonder vanwege 'hun grote kennis en ervaring met het bedrijfsleven in het algemeen en buiten Nederland in het bijzonder (...) d.w.z. het bezit van internationale relaties'. In de volgende paragraaf beschrijven we hoe we gegevens verzameld hebben over op Indonesië georiënteerde bedrijven, hun directeuren en commissarissen. Het zijn de daaruit resulterende netwerken van dubbelfuncties die we vervolgens analyseren. Als Smit gelijk heeft met zijn observatie, zal de veranderende structuur van dat netwerk iets zeggen over de herstructurering en heroriëntering van het op Indonesië georiënteerde bedrijfsleven.

\section{Methode en gegevens}

\section{Dubbelfuncties en netwerken}

In Nederlandse bedrijven wordt de leiding uitgeoefend door een Raad van Bestuur, of directie. Een Raad van Commissarissen houdt daarop toezicht. Er ontstaat een dubbelfunctie tussen twee bedrijven als één persoon zo'n topfunctie in twee bedrijven uitoefent. De betekenis van een dubbelfunctie kan op verschillende, niet nood- 
zakelijk tegenstrijdige, manieren geduid worden. Vanuit het perspectief van de betrokken topfunctionaris is het een middel om zijn maatschappelijke kennis en ervaring te benutten maar tegelijk ook om zijn macht, inkomen en prestige te vergroten. Als de bestuurders en commissarissen eenzelfde sociale achtergrond hebben, wordt zo wat wel een klassenhegemonie is genoemd, instandgehouden. Vanuit de onderneming bezien ontstaat er een efficiënt kanaal om informatie te vergaren en over te dragen. Een goed ontwikkeld netwerk van dubbelfuncties kan zo bijdragen aan de efficiënte totstandbrenging van een strategische consensus. In specifieke gevallen behelst de informatie ook controle, en wordt de bestuurssamenstelling gebruikt om invloed uit te oefenen. Dat wordt wel financiële hegemonie genoemd.

Naarmate iemand meer topfuncties bekleedt, verbindt hij meer bedrijven en ontstaan er exponentieel veel meer dubbelfuncties. Zulke big linkers zijn van groot belang voor de consensus- en strategievorming. Als een big linker met zijn posities vier bedrijven verbindt, creëert hij zes dubbelfuncties. Maar als hij bij tien bedrijven bestuursfuncties bekleedt, brengt hij al 45 dubbelfuncties tot stand. Naarmate twee bedrijven een groter aantal functionarissen gemeenschappelijk hebben, nemen we aan dat de relatie tussen deze bedrijven intensiever is. Met andere woorden, hechte verbindingen tussen bedrijven worden geïndiceerd door een hoger aantal dubbelfuncties. Door enkelvoudige dubbelfuncties tussen bedrijven buiten de analyse te houden, zullen we eveneens een beter inzicht in de structuur van het netwerk kunnen krijgen.

Voor een meer uitgebreide en formele bespreking van assumpties en methodologie van onderzoek naar dubbelfuncties verwijzen we kortheidshalve naar de literatuur (Wasserman \& Faust, 2000; Scott, 2000). Voor de analyse van het netwerk maken we gebruik van definities en maten die zijn ontleend aan de grafentheorie. De bedrijven beschouwen we als punten, die door lijnen (dubbelfuncties) met elkaar verbonden zijn. ${ }^{3}$ Bedrijven (punten) staan centraal in het netwerk als ze met veel andere bedrijven verbonden zijn (lijnen kennen). Als ze daarentegen geheel niet door dubbelfuncties met andere bedrijven verbonden zijn, zijn ze in het netwerk geïsoleerd. Groepen van bedrijven zijn onderling hecht verbonden als veel van de mogelijke dubbelfuncties zich in werkelijkheid ook voordoen. De dichtheid is gedefinieerd als het aantal bestaande lijnen gedeeld door het aantal mogelijke lijnen tussen een gegeven aantal punten. In een clique komen alle mogelijke lijnen voor, en is de dichtheid per definitie 100 procent.

\section{Gegevensverzameling}

We hebben voor een steekproef van 141 bedrijven voor vijf jaren de netwerken dubbelfuncties geconstrueerd. De steekproef is bepaald voor het laatste volle jaar vóór de dekolonisatie, 1948. De vijf jaren waarvoor gegevens verzameld zijn, zijn 1946, 1950, 1954, 1958 en 1962. Als 1949 en 1957 de politieke en de economische dekolonisatie markeren, zijn alle te onderscheiden periodes vertegenwoordigd. 
Voordat we de steekproeftrekking beschrijven, is het nuttig om expliciet te wijzen op het panelkarakter van de steekproef. Dat heeft ten minste de volgende consequenties:

- Door de economische dynamiek worden bedrijven geliquideerd of overgenomen. In de loop van de jaren doet zich dus een zekere paneluitval voor. Afgezien van ontbrekende brongegevens of meetfouten, is er dan sprake van een reële ontwikkeling.

- Tegelijk is die reële ontwikkeling er ook een van toenemende bedrijvigheid. Als we met onze steekproef in 1948 (ook) de kern van het Nederlandse bedrijfsleven te pakken hebben, gaat dat niet meer vanzelfsprekend op voor het begin van de jaren zestig. Een voor 1962 met onze criteria voor 1948 bepaalde steekproef zou er denkelijk anders uitgezien hebben, afgezien van het feit dat Nederlands economische betrokkenheid op Indonesië toen vrijwel nihil was.

Overeenkomstig het dubbele belang van Nederland bij Indië hebben we verschillende selecties ontwikkeld: één van in Indië werkzame en één van bij de Nederlandse export naar Indië betrokken bedrijven. De eerste selectie was relatief eenvoudig te identificeren. Als uitgangspunt fungeerden alle in 1948 op de Amsterdamse Beurs genoteerde in Indonesië werkzame bedrijven met een balanstotaal van minimaal vier miljoen gulden. Als aanvullend criterium werd zo nodig het lidmaatschap van een Nederlands-Indische ondernemersorganisatie gehanteerd. Uiteindelijk resteerden 93 in Indonesië werkzame bedrijven, waarvan wij voor de onderzoeksjaren de namen van directeuren en commissarissen achterhaald hebben. Voor de bij de export naar Indië belang hebbende bedrijven hebben we een getrapte procedure moeten volgen, omdat gegevens over deze export niet (systematisch) per bedrijf bekend waren. Daarom hebben we allereerst sectoren geselecteerd waarvoor Indonesië een belangrijk (minimaal tien procent in 1938) afzetgebied was. Daaraan zijn een aantal bedrijfstakken in de circulatiesfeer toegevoegd: handel, scheep- en luchtvaart, en bankwezen. Van de geselecteerde sectoren hebben we telkens de maximaal tien grootste bedrijven genomen. Uiteindelijk hebben we zo 69 bij de handel naar Indië betrokken bedrijven geselecteerd. Voor elk van deze sectoren geldt dat de geselecteerde bedrijven tezamen meer dan 70 procent van de totale balanssom van de bedrijfstak in Van Oss' Effectenboek vertegenwoordigen.

In totaal hebben we zo 141 bedrijven geselecteerd (zie tabel 2). Een aantal bedrijven komt in beide selecties voor. Het gaat daarbij om tien handelsfirma's, vier rederijen, twee banken (NHM en NIHB), en verder Heineken, KLM, Philips, Shell en Unilever. Heineken, Philips en Unilever stichtten in de jaren dertig dochterondernemingen in Indonesië. NHM, begonnen als de Factorij ofwel de Nederlandsche Handelmaatschappij, en Shell, van oorsprong de Koninklijke Nederlandsche Maatschappij tot Exploitatie van Petroleumbronnen in Nederlandsch-Indië, zijn daarentegen ondernemingen die zich op succesvolle wijze en relatief vroeg van hun koloniale wortels ontdaan hebben. Deze eenentwintig bedrijven zijn zowel in Indië als in Nederland actief. Om die reden noemen we ze hier het binationale segment 
Tabel 2: De geselecteerde bij Indië betrokken bedrijven per bedrijfstak, 1948

\section{In Indië werkzaam}

\begin{tabular}{|c|c|c|c|}
\hline Georiënteerd op de Indische & & Productiesfeer & \\
\hline industrie & 16 & metaal en elektrotechniek & 9 \\
\hline mijnbouw (kolen) & I & scheepsbouw & 6 \\
\hline spoorwegen & 8 & textiel & 6 \\
\hline gas en elektriciteit & 2 & chemie & 8 \\
\hline Georiënteerd op de export & & voeding & 9 \\
\hline cultures & 30 & Circulatiesfeer & \\
\hline mijnbouw (olie, tin) & 5 & handel & 10 \\
\hline Handel en verkeer & & scheepvaart & 10 \\
\hline handel & 18 & luchtvaart & I \\
\hline scheepvaart & 5 & banken & 10 \\
\hline luchtvaart & 1 & & \\
\hline \multicolumn{4}{|l|}{ Bank- en verzekeringswezen } \\
\hline banken & 4 & & \\
\hline verzekeringswezen & 3 & & \\
\hline Totaal & 93 & & 69 \\
\hline
\end{tabular}

\section{Bij export naar Indië betrokken}

van de steekproef. Hun omvang is echter zo groot, en hun activiteiten en belangen zijn al zodanig gespreid, dat hun werkzaamheden in Indië voor de totale bedrijfsvoering van relatief minder belang zijn. Het Indonesische segment bestaat zo uit $(93-21=) 72$ bedrijven en het Nederlandse segment uit $(69-21=) 48$ bedrijven.

Voor de geselecteerde bedrijven hebben we vervolgens de namen van de leden van de Raden van Bestuur en van Commissarissen in de onderzoeksjaren verzameld. Als bronnen daarvoor zijn de gepubliceerde jaarverslagen gebruikt en eventueel Van Oss' Effectenboek. Slechts voor 1950 konden voor alle geselecteerde bedrijven deze namen achterhaald worden. De uitval is het grootst voor 1962 en voor het Indonesische segment. De steekproef bedraagt dan nog 115 bedrijven, 20 van de 26 uitgevallen bedrijven behoren tot het Indonesische segment.

Tabel 3 vat een aantal kenmerken van de netwerken samen. Van de bedrijven zijn per onderzoeksjaar gemiddeld ongeveer tien namen van directeuren en commissarissen opgenomen. Voor het Indonesische segment ligt dat gemiddelde lager (op 6,9 à 7,8), en voor het binationale segment schommelt het tussen de 13,5 en 15,6. Binnen het Nederlandse segment stijgt het aantal directeuren en commissarissen echter gestaag, van 10,6 tot 12,0. Tot 1954 vond deze stijging ook in de andere segmenten plaats, maar daarna niet meer. Uit ander onderzoek is het verband tussen de omvang van een bedrijf en het aantal topbestuurders bekend. Grosso modo 
Tabel 3: Kenmerken van de dubbelfunctienetwerken, 1946-1962

\begin{tabular}{lccccc}
\hline & 1946 & 1950 & 1954 & 1958 & 1962 \\
\hline Aantal bedrijven & 137 & 141 & 135 & 131 & 115 \\
Aantal functies & 1279 & 1386 & 1390 & 1313 & 1156 \\
Functies per bedrijf & 9,3 & 9,8 & 10,3 & 10,0 & 10,1 \\
\hline Aantal functionarissen & 848 & 914 & 890 & 847 & 753 \\
Aantal dubbelfunctionarissen & 198 & 222 & 232 & 216 & 204 \\
\% Dubbelfunctionarissen & 23,3 & 24,3 & 26,1 & 25,5 & 27,1 \\
Functies per dubbelfunctionaris & 3,18 & 3,13 & 3,16 & 3,16 & 2,98 \\
\hline Aantal dubbelfuncties & 1002 & 1056 & 1133 & 1053 & 823 \\
Aantal lijnen & 734 & 771 & 812 & 754 & 579 \\
Gemiddeld gewicht per lijn & 1,37 & 1,37 & 1,4 & 1,4 & 1,42 \\
Dichtheid & 7,9 & 7,8 & 9,0 & 8,9 & 8,9 \\
Geïsoleerde bedrijven *) & 13 & 12 & 8 & 9 & 7 \\
Samenhang & 82 & 84 & 86 & 87 & 85 \\
\hline
\end{tabular}

$*)=$ in 1954 en 1962 bovendien een component van twee bedrijven

bevestigt een en ander dan ook dat het binationale segment de grootste bedrijven herbergt maar dat na 1954 de opmars van het Nederlandse segment doorzet.

$\mathrm{Er}$ is in onze onderzoeksperiode een kern van 200 tot 230 dubbelfunctionarissen of lijnendragers. In verhouding tot de overige, enkelvoudige directeuren en commissarissen groeit hun aantal enigszins, van 23,3 tot 27,1 procent van het aantal geselecteerde functionarissen. Gezien de daling van het totaal aantal bedrijven in onze steekproef zou die stijging echter uitgelegd kunnen worden als een artefact: het zouden immers vooral de marginale en geïsoleerde bedrijven kunnen zijn die afvallen.

Opmerkelijk is dat rond 1960 het aantal functies per lijnendrager daalt: tussen 1946 en 1958 lag dat gemiddeld tussen de 3,1 en 3,2 terwijl het in 1962 iets onder de 3,o uitkwam. Dat duidt op een lichte afname, een aftopping van deze cumulatie na 1958. Duidelijker zichtbaar is dat voor wat Useem (1979) de big linkers noemt, de lijnendragers met minimaal vier functies. In deze groep loopt het gemiddelde aantal bestuursfuncties af van 5,6 in 1946 tot 5,1 in 1962. Een en ander is consistent met Schijfs stelling (1993) dat de verbindingen tussen de bedrijven rond 1900 veel personalistischer waren dan in Graven naar Macht over dubbelfuncties in 1969 wordt beweerd.

Wie de grote functieverzamelaars in onze netwerken zijn, is aangegeven in tabel 4. Merendeels zijn zij directeur (geweest) bij een van de grote Nederlandse handelsbanken. De NHM springt eruit, met maar liefst vier president-directeuren: Heldring, 
Tabel 4: De functieverzamelaars in het bij Indonesië betrokken bedrijfsleven, 1946-1962

\section{Naam Topjaar(n) Functies in topjaar}

H. Cremer

E. Heldring

M.C. Koning

H.F. van Leeuwen

K.P. van der Mandele

D.A. Delprat

C.J. Baron Collot d'Escury

J.M. Haga

H.L.Woltersom

H.L. van Eeghen

H.M. Hirschfeld

A.A. van Sandick

H.Albarda

J.A.G. Jonckheer

H.W.A. van den Wall Bake 1962 (I2)
1946 (13) Deli Mij, De Oostkust, A'damsche Bank, Bandar Olie, Bandar Rubber, Deli Spoorweg Mij, Kasvereniging, Majanglanden, NDSM, NSU, R'damse Lloyd, Senembah, Werkspoor

1946 (8) NHM, Hoogovens, KJCPL, KNSM, KPM, NSU, SMN, Ver, Javasche Houthandel

1946 (I0) A'damsche Bank, Hoek's Machinefabriek, HVA, KPM, NDSM, NISHM, NSU, SMN, Werkspoor, Zeehaven en Kolenstation Sabang

1946 (8) Twentsche Bank, Demka, Dikkers, Hoogovens, HVA, KLM, Naarden, NDSM

1946 (I0) Van den Bergh \& Jurgens, HAL, Lever's Zeepmij, Ned. Bank, Van Nievelt-Goudriaan, RDM, R'damsche Bank, Stokvis, Stork, Unilever

1950 (8) SMN, NSU, ANIEM, Heemaf, KJCPL, KNSM, KPM, Twentsche Bank

954 (14) NHM, Fokker, Heineken, Hoogovens, KJCPL, KNSM, KPM, Lindeteves, Müller, Naarden, NSU, Shell, SMN, Werkspoor

1954 (9) A'damsche Bank, Blaauwhoedenveem, Gending, Hoogovens, Oost-Java Stoomtram, Semarang-Joana Stoomtram, SemarangCheribon Stoomtram, Serajoedal Stoomtram, Sumatra Caoutchouc

1954 (8) R'damsche Bank, Van den Bergh \& Jurgens, HAL, Hoogovens, KLM, Philips, Stokvis, Unilever

1958 (8) Kasvereniging, KNSM, Nat. Levensverzekering Bank, Ned. Bank, NHM, NSU, SMN, Vorstenlandse Cultures

1958 (I2) HAL, HVA, KJCPL, KNZI, KPM, Ned. Bank, Van Ommeren, Philips, R'damse Bank, Spanjaard, Unilever,Victoria

1958 (10) NHM,Albatros, Hoogovens, KJCPL, KNSM, KPM, NDSM, SMN, Veenendaal,Werkspoor

1962 (9) NHM, KLM, AKU, Heemaf, Heineken, Naarden, Olveh van I879, Van Ommeren, De Schelde

1962 (II) SMN, NSU, ADM, Bandar Rubber, Hoogovens, Kasvereniging, KNSM, Moluksche Handelsver, Philips, Tels, Ver. Javasche Houthandel

NHM, Demka, Fokker, Hoogovens, KJCPL, KNSM, De Kondor, KPM, Naarden, SMN,Ver. Javasche Houthandel,Wilton 
Collot d'Escury, Van Sandick en Van den Wall Bake. Opvallend is de continuïteit in hun nevenfuncties. Rotterdam is voorts herkenbaar aanwezig met Van der Mandele, Woltersom en Hirschfeld. Cremer, de president-directeur van de Deli Maatschappij is de meest uitgesproken koloniale ondernemer. In Nobel, Fennema en Koopman (1983) presenteerden we overigens ook een lijst van lijnendragers tussen overheid en bedrijfsleven. Enigszins gechargeerd komen in die lijst vooral Rotterdammers voor, terwijl de Amsterdamse banken het netwerk binnen het bedrijfsleven domineren. Het belang van de grote functieverzamelaars voor de omvang en structuur van de netwerken kan overigens moeilijk overschat worden. In 1946 genereren Cremer, Heldring, Koning, Van Leeuwen en Van den Wall Bake met zijn vijven 224 dubbelfuncties tussen bedrijven. Dat is bijna een kwart van het totaal aantal dubbelfuncties in dat jaar. Het grootste deel van deze 224 dubbelfuncties bestaat overigens uit de hierboven secundair genoemde dubbelfuncties, die we in de analyses hieronder buiten beschouwing zullen laten.

\section{Segmenten, sectoren en bedrijfsgroepen}

\section{De segmenten}

De samenstelling van de drie segmenten vloeit voort uit de overlappende steekproeftrekking. De segmentering behelst echter beslist ook een zekere onderliggende logica. In ietwat gechargeerde bewoordingen: het Indonesische segment vertegenwoordigt het kleinere koloniaal kapitaal, het Nederlandse segment staat voor het industriële kapitaal, en het binationale segment omvat het internationale handelskapitaal. Het kleinere koloniaal kapitaal zetelde in Indië en Amsterdam maar evenzeer in Den Haag (zie voor een vergelijkbare conclusie voor de vooroorlogse jaren Taselaar, 1998: 53. Den Haag was favoriet bij spoor- en tramwegmaatschappijen, bij petroleum- en mijnbouwmaatschappijen en diverse cultuurmaatschappijen). Het binationale segment had van oorsprong een mondiale, of in elk geval Atlantische blik. Amsterdam was zijn uitvalsbasis en zijn vertegenwoordigers hielden enige afstand van politiek en overheid. Het Nederlandse segment was van nature daarentegen eerder op het Europese continent georiënteerd. Het had Rotterdam als toegangspoort tot het Duitse achterland, en was niet wars van overheidsinterventie. Hirschfeld was in onze periode misschien wel zijn meest prototypische voorman, mede omdat hij ook tal van werkzaamheden voor de Nederlandse overheid uitvoerde, zowel in het kader van de dekolonisatie als met het oog op de industrialisatie. Het bijzondere van Hirschfeld is dat hij zich in zijn opvattingen en beleid een Atlanticus toonde.

Hoe ontwikkelen de netwerken zich op dit niveau en hoe sterk is het onderscheid van de segmenten, heeft hun onderscheid ook los van de steekproeftrekking enige validiteit? Hierboven bleek een klein aantal very big linkers sterk bepalend voor het aantal lijnen. Vanwege dit laatste beperken we ons hier tot een analyse van het directeurennetwerk, het gerichte netwerk dat gegenereerd wordt door uitsluitend 
Grafiek 2: De dichtheden binnen en tussen de drie segmenten van het bedrijfsleven

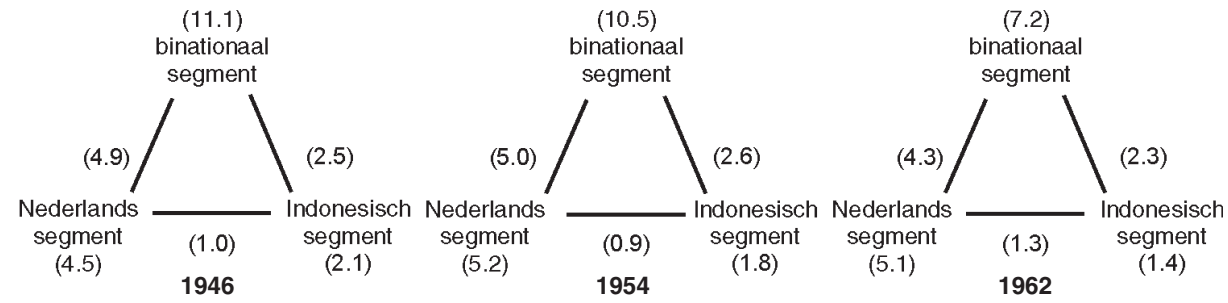

degenen die in een Raad van Bestuur zitting hebben met verwaarlozing van de daardoor gegenereerde secundaire dubbelfuncties.

In de vorige paragraaf hebben we al geconstateerd dat het Indonesische segment het geringste aantal bestuurders kende, en de grootste uitval aan bedrijven. Onderling zijn de bedrijven in dit segment het minst verbonden, zoals blijkt uit grafiek 2 . De dichtheid komt in 1946 uit op 2,1 procent en daalt nog tot 1,4 procent in 1962. In het binationale segment ligt deze dichtheid juist op het hoogste niveau, 11,1 procent in 1946, maar daalt deze eveneens, tot 7,2 procent in 1962. Het Nederlandse segment zit daartussenin, en is het enige waarin de dichtheid stijgt, van 4,5 tot 5,1 procent. De verbindingen tussen de sectoren zijn steeds het minst dicht tussen het Indonesische en het Nederlandse segment, schommelend rond de één procent. Het binationale segment is duidelijk meer met het Nederlandse dan met het Indonesische verbonden. Uit een vergelijking van deze dichtheden binnen en tussen sectoren blijkt zelfs dat voor bedrijven uit het Indonesische segment de kans groter is dat ze met een binationaal bedrijf dan met een ander bedrijf uit hun eigen segment verbonden zijn. Deze structuur doet denken aan het centrum-periferiemodel, met het binationale segment als centrum, dat de beide nationale periferieën met elkaar in verbinding brengt. In de loop van de tijd valt de ene periferie, de Indonesische, echter uit elkaar. De andere periferie, de Nederlandse, vergroeit als het ware met het binationale centrum.

Dit lijkt op een zekere circulariteit in de analyse te wijzen. Het bestaan van aparte segmenten wordt immers verondersteld, in plaats van bewezen. Daarom hebben we de validiteit van onze segmentering als volgt empirisch getoetst. Zonder verdere assumpties hebben we in de netwerken gezocht naar een centrum. De kern daarvan hebben we gedefinieerd als de deelverzameling van de meest centrale bedrijven binnen de grootste component. Daarbij hebben we de rush als maat voor centraliteit gebruikt. De rush geeft aan hoe vaak een bedrijf op het kortste pad ligt dat twee andere bedrijven met elkaar verbindt. Bedrijven met een relatief hoge rush kanaliseren en structureren de informatie- en invloedsrelaties tussen alle ondernemingen in hun directe omgeving. Er bestaat telkens een kern van zo'n 15 procent van de bedrijven in het netwerk die een relatief hoge rush hebben. De resterende bedrijven uit deze grote component vormen de buitenring van het centrum. De overige bedrijven vor- 
Tabel 5: De centraliteit van de segmenten

\section{$1946 \quad 1954 \quad 1962$}

$\begin{array}{lllllllllll}\text { (a) } & \text { (b) } & \text { (c) } & \text { (d) } & \text { (a) } & \text { (b) } & \text { (c) } & \text { (d) } & \text { (a) } & \text { (b) } & \text { (c) }\end{array}$

\begin{tabular}{lrrrrrrrrrrrr}
\hline Indonesisch & 7 & 56 & 37 & 71 & 3 & 75 & 22 & 67 & 2 & 50 & 48 & 52 \\
Nederlands & 17 & 54 & 28 & 46 & 19 & 62 & 19 & 47 & 22 & 51 & 27 & 45 \\
Binationaal & 40 & 45 & 15 & 20 & 29 & 62 & 10 & 21 & 17 & 72 & 11 & 18 \\
\hline
\end{tabular}

Legenda:
(a) $=$ kern, in \% van (d)
(c) = periferie, in \% van (d)
(b) = buitenring, in \% van (d)
(d) = aantal bedrijven per segment

men de periferie. Ze behoren niet tot de grootste component of zijn zelfs geïsoleerd.

In tabel 5 vergelijken we deze empirische indeling met de a priori-indeling in segmenten. De samenstelling van de kern bevestigt de analyse van grafiek 2. In 1946 behoren 40 procent van de binationale bedrijven en 17 procent van de Nederlandse tot de kern. In 1962 is dit verschil verminderd en zijn de verhoudingen zelfs omgedraaid. Dan hoort 17 procent van de binationale en 22 procent van de Nederlandse bedrijven tot de kern. Aanvankelijk bestaat de kern overwegend uit Amsterdamse bedrijven, maar in de loop van de jaren vallen enkele daarvan uit de kern weg en komen er meer Rotterdamse bedrijven voor in de plaats. Verder is het duidelijk dat het Indonesische segment het meest perifere is. Het levert de grootste bijdrage aan de buitenring en de periferie. En zijn bijdrage aan de kern neemt nog af door de tijd. Eén detail is interessant in dit verband. De Escomptobank, één van de koloniale banken, blijkt in 1946 tot de kern te behoren zonder zelf met één van de andere bedrijven in deze kern verbonden te zijn. Deze bank is als het ware een spil van een deelverzameling van minder centrale bedrijven zoals een aantal cultuurmaatschappijen. De Escomptobank is zo bij uitstek een perifeer centrum. Haar Indonesische belangen werden in 1960 genationaliseerd. Haar resterende Nederlandse belangen werden ondergebracht in de Nedescobank, die uiteindelijk door de Nederlandse Overzee Bank werd overgenomen.

\section{De sectoren}

Binnen één en dezelfde sector zullen bedrijven over het algemeen met overeenkomstige omstandigheden te maken hebben. Tussen sectoren zullen deze daarentegen verschillen. Voor sommige sectoren zal het eenvoudiger zijn geweest zich aan te passen aan de veranderende omgeving dan voor andere. De mogelijkheden om nieuwe producten en/of markten aan te boren verschilden. En veel maatregelen van de nieuwe Indonesische overheid waren vooral gericht op de voor haar strategische sectoren, in plaats van op het gehele bedrijfsleven of één enkel bedrijf. Ook de relaties tussen de sectoren kunnen als een netwerk gepresenteerd en geanalyseerd worden. 
Grafiek 3: De dichtheden tussen de sectoren van het bedrijfsleven
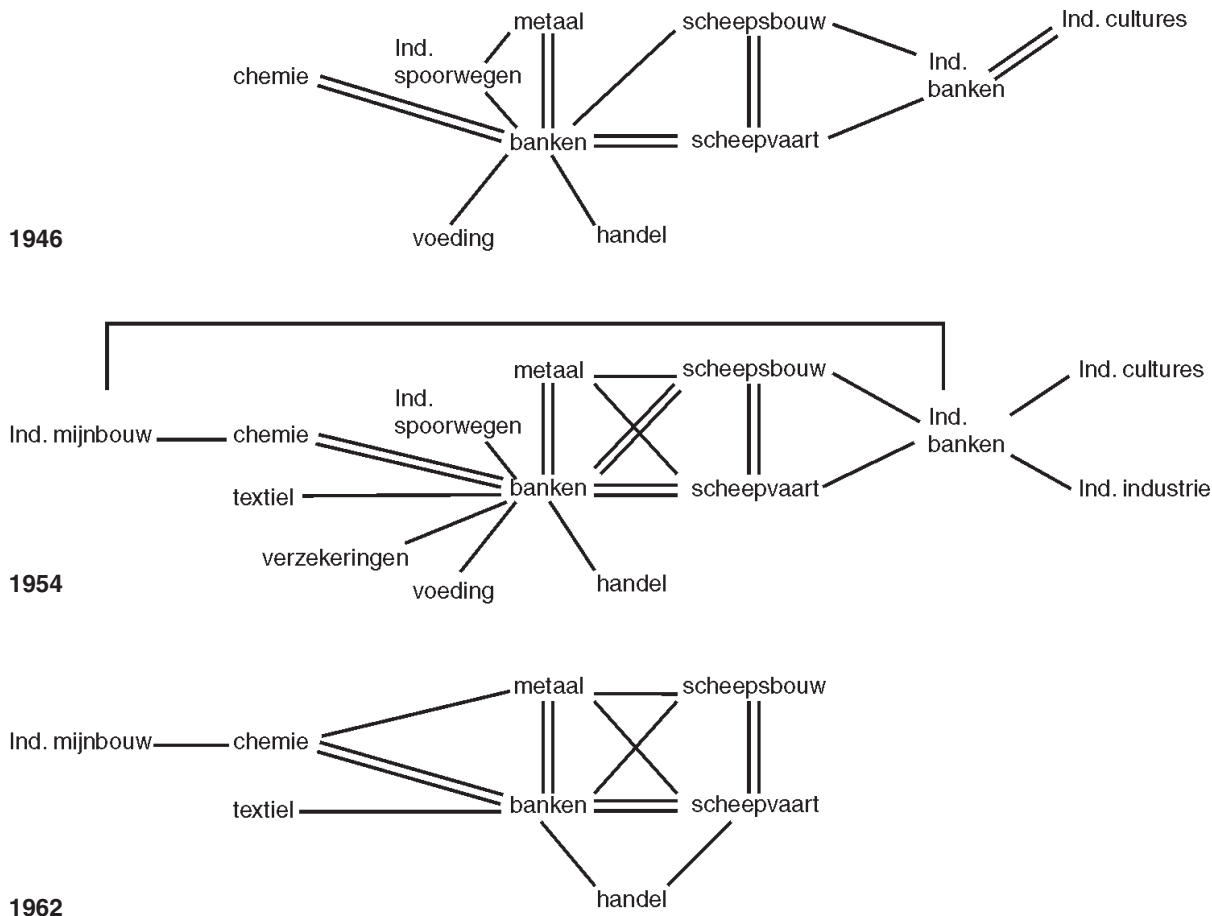

In dat netwerk van sectoren noemen we twee sectoren (zeer) nauw verbonden als hun bipartite dichtheid de 5 (10) procent te boven gaat. Het resultaat is weergegeven in grafiek $3 .{ }^{4}$

In 1962 is er een centrale clique van vier sectoren: de banken, de metaal, de scheepvaart en de scheepsbouw. Deze tekent zich al eerder af en is ook na onze onderzoeksperiode nog wel herkenbaar. Als we deze centrale clique van vier sectoren uit de netwerken zouden weglaten, zou er aan de ene kant (in 1946 en 1954) een Indonesische component van banken en cultures en aan de andere kant een aantal Nederlandse industriële bedrijfstakken resteren. De bijzondere positie daarin van de Indonesische mijnbouw en spoorwegen komt hieronder nog aan de orde.

In 1946 kent het netwerk van sectoren twee centrale sectoren: de Nederlandse en de Indonesische banken. Dat de banken in het netwerk van sectoren een centrale positie innemen, ligt in de lijn van bevindingen voor andere perioden en landen. Binnen de Nederlandse banksector zelf staat de Nederlandsche Bank voortdurend centraal. Tussen de vier grote handelsbanken onderling bestaan er nimmer dubbelfuncties, evenmin overigens als in later jaren tussen de ABN en de AMRO.

Op de bijzondere positie van de Escomptobank als perifeer centrum hebben we aan het einde van de vorige subparagraaf al gewezen. De Indonesische overheid kocht alle aandelen op van de circulatiebank, de (voormalige) Javasche Bank (die tra- 
ditioneel goede banden met De Nederlandsche Bank onderhield) en vormde deze in 1953 om tot een staatsorgaan met als taak onder meer het toezicht op het kredietbeleid van de handelsbanken. Eén koloniale handelsbank, de NIHB, was zelfs in 1954 nog in staat winsten naar Nederland over te boeken. Maar haar Indonesische belangen werden genationaliseerd na 1957, en het restant werd overgenomen door de Rotterdamse Bank waarna ze uit de beursnotering verdween. In het netwerk van alle, Nederlandse en Indonesische, banken gezamenlijk vormen de centrale banken, De Nederlandsche Bank en de Java Bank, de ontmoetingsplaatsen voor de belangrijkste handelsbanken. De koloniale handelsbanken, de Escomptobank en de NIHB, waren opvallend genoeg geen van alle rechtstreeks verbonden met de NHM, de Nederlandse handelsbank met de sterkste koloniale wortels. Met het wegvallen van de Indonesische banken uit het netwerk door de nationalisaties in de jaren vijftig verliezen de cultuurmaatschappijen en de Indonesische industrie hun toegang tot het Nederlandse netwerk.

De Indonesische sectoren zijn in 1962 uit beeld verdwenen, met één uitzondering. De nauwe relaties tussen de Indonesische mijnbouw en de Nederlandse chemie hebben alles te maken met Shell: twee van de Indonesische mijnbouwondernemingen in het netwerk, de Dordtsche Petroleum Maatschappij en Moeara Enim, zijn dochters van Shell, en een derde, de Billiton Maatschappij, is door Shell overgenomen gedurende de jaren zestig. In het verlengde hiervan maken we een paar korte observaties over andere Indonesische sectoren.

- Het traditionele belang van de cultuurmaatschappijen is zichtbaar in staat 1 . Van de 30 cultuurmaatschappijen komen er in 1958 nog maar 23, en in 1962 slechts 16 in onze netwerken voor. De omvang van hun bestuursorganen en hun onderlinge verbondenheid neemt continu af. Ze maken steeds minder deel uit van het netwerk. In een aantal gevallen, bijvoorbeeld wanneer de Deli Maatschappij in 1953 een aantal ondernemingen overneemt, hangt het verdwijnen van bedrijven en dubbelfuncties samen met het versimpelen en formaliseren van concernstructuren. Enkele dubbelfuncties ontstaan ook doordat een administratiekantoor als Tiedeman \& Van Kerchem de Indonesische directie voert. Vaker echter werden cultuurmaatschappijen verkocht of geliquideerd. Baudet en Carrière (1970) hebben het opvallende gebrek aan samenwerking en fusies tussen bedreigde cultuurmaatschappijen verklaard door te wijzen op de traditionele (familie)eigendomsverhoudingen. Reorganisaties zouden de bestuursorganen in Nederland aangetast hebben die zowel relatief topzwaar, onproductief en hebzuchtig als kortzichtig waren.

- De zeer nauwe relaties tussen de Indonesische spoorwegmaatschappijen en de Nederlandse metaalindustrie respectievelijk de Nederlandse banken lijken goed verklaarbaar vanuit de leverancier-afnemerverhouding respectievelijk de omvang van de beleggingen, zij het dat het materieelbestand inmiddels sterk verouderd was. Vanaf de soevereiniteitsoverdracht onderhandelt de gezamenlijke directie met de Indonesische overheid over een overname. Na 1958 bestaan de bedrijven nog slechts op papier. 
Het grootste deel van de bedrijven begon pas na 1949 te zoeken naar mogelijkheden elders. Een aantal Indonesische bedrijven is wel tijdig, zelfs vóór de oorlog, begonnen met een heroriëntatie op nieuwe producten en landen. Baudet (1983) noemt op basis van jaarverslagen onder andere de OGEM, de Billitonmaatschappij en Hagemeijer. De grote cultuurondernemingen (Deli, HVA, RCMA) volgden in de jaren vijftig, mede vanwege hun kapitaalkrachtigheid. Productdifferentiatie in Indonesië zelf bood uiteindelijk weinig soelaas. En nieuwe vestigingen in andere ontwikkelingslanden leidden in de jaren vijftig en zestig voor deze bedrijven nog afgezien van de andere taal en gewassen tot problemen vergelijkbaar met die in Indonesië. Immers, ook elders streefde men naar dekolonisatie. Wel wisten in de jaren vijftig in Indonesië onder meer de HVA en de Rubber Cultuur Maatschappij Amsterdam (RCMA) een voorkeursbehandeling te verwerven inzake deviezen en personeelsvoorziening door vroegtijdig en ten principale goede verhoudingen met de nieuwe Indonesische overheid na te streven. Maar ook aan die voorkeursbehandeling kwam in 1957 een einde.

De grootste van de cultuurmaatschappijen, de HVA, is in geen van de onderzoeksjaren door een dubbelfunctie met één der andere cultures verbonden. Volgens Taselaar (1998: 70) moet het ontbreken van dubbelfuncties van de HVA-directeuren een bewuste keuze zijn geweest. Met welke bedrijven de HVA wel verbonden is, valt af te leiden uit staat 3, waar de heren Koning en Van Leeuwen de lijnen leggen naar de Amsterdamsche Bank en de scheepvaart respectievelijk de Twentsche Bank en de metaal. Geen van de andere in deze alinea genoemde Indonesische bedrijven kent een markante positie in het netwerk van dubbelfuncties.

\section{Bedrijfsgroepen}

Terloops hebben we hierboven gewezen op de aanvankelijke dominantie van Amsterdamse bedrijven in het netwerk. In deze subparagraaf zoeken we meer systematisch naar groepen van bedrijven, en veranderingen in hun samenstelling. In de literatuur (zie het overzichtsartikel van Fennema en Schijf, 1979) worden hiervoor allerlei termen gebruikt als interest groups (Sweezy, 1953), financial groups (Dooley, 1969), spheres of influence (Levine, 1972), en constellations of interests (Scott, 1979). Onze onderzoeksstrategie komt op twee soorten analyse neer: allereerst zoeken we in het directielijnennetwerk naar de invloedssferen rond de strategische banken, vervolgens richten we ons op de meervoudige lijnen in het dubbelfunctienetwerk: naarmate bedrijven meer directeuren en commissarissen delen, zullen zij een meer gemeenschappelijke oriëntatie en strategie hebben.

Omdat het aantal lijnen in dit directielijnennetwerk per definitie geringer is, is de grootste component kleiner en de dichtheid daarbinnen geringer dan in de netwerken van alle dubbelfuncties. Om na te gaan welke bedrijven een centrale, strategische positie in dit directielijnennetwerk innemen, maken we opnieuw gebruik van de rush. In staat 6 is weergegeven om welke bedrijven (met een rush van meer dan één procent) het dan gaat. Het aantal van zulke strategische bedrijven neemt 
meer dan evenredig af, van 21 (van de 137) tot 14 (van de 115). Van de tien bedrijven die in 1946 en in 1962 een strategische positie innemen, behoren er drie tot het binationale, zes tot het Nederlandse en één tot het Indonesische segment. De elf bedrijven die in 1946 wel maar in 1962 niet meer strategisch mogen heten, komen grotendeels uit het Indonesische (4) en het binationale (5) segment. Daar staat tegenover dat alle vier de bedrijven die in 1946 niet maar in 1962 wel strategisch zijn gelegen, tot het Nederlandse segment behoren. Zo komen er in 1962 zelfs relatief meer strategisch gepositioneerde bedrijven uit het Nederlandse $(22 \%)$ dan uit het binationale (17\%) segment.

Een buitenbeentje onder de strategische banken is de Escomptobank. In 1946 is deze met geen enkel ander strategisch bedrijf verbonden door een directielijn, in 1954 met slechts één (de KPM). Dit onderstreept de eerdere conclusie dat deze bank het perifere subcentrum bij uitstek is. De andere grote koloniale handelsbank, de NIHB, heeft veel meer verbindingen met andere strategische bedrijven zoals de KLM, de NDSM en de SMN. Terwijl de Escomptobank vrijwel uitsluitend met niet-strategische bedrijven verbonden is, zijn enkele andere bedrijven overwegend met strategische bedrijven verbonden. Dat geldt het duidelijkst voor de Hoogovens en NDSM. De eerste is gemiddeld met slechts 4 niet-strategische bedrijven verbonden, verder met 4 strategische banken en 4 andere strategische bedrijven. De tweede is in 1946 en 1954 met 2 niet-strategische bedrijven, 4 respectievelijk 3 strategische banken en 5 respectievelijk 4 andere strategische bedrijven verbonden. Evenzo oriënteren in 1954 AKU en KNSM zich overwegend op andere strategische bedrijven.

Zowel in de literatuur als in de bovenvermelde analyses nemen de banken een bijzondere rol in. Als die positie zodanig is dat de banken als centra van groepen of invloedssferen mogen worden beschouwd, kunnen we die groepen construeren door alle bedrijven eraan toe te rekenen die alleen met die ene bank en niet met andere door een directielijn verbonden zijn. Bedrijven die buiten zo'n invloedssfeer blijven, zijn ofwel met geen enkele of met twee of meer banken verbonden. In het eerste geval is het bedrijf te onbeduidend, in het tweede geval probeert het zijn contacten, belangen en risico's te spreiden, terwijl verschillende banken erin geïnteresseerd zijn. Bij deze laatste categorie gaat het vooral om zeer grote en kapitaalintensieve bedrijven zoals de meer genoemde Hoogovens.

Voor het Interbellum komt Taselaar (1998: 67) tot vier clusters in het Indische bedrijfsleven rond de banken, te weten rond de NHM, de NIHB, De Nederlandsche Bank en de Amsterdamsche Bank, waarvan het tweede en het derde onderling nauw samenhingen. Daarnaast onderscheidt hij vijf grote clusters van cultuurmaatschappijen, twee clusters van respectievelijk scheepvaart- en stoomtrammaatschappijen, en twee van mijnbouwmaatschappijen. Globaal correspondeert dit beeld sterk met de beschrijving die Nobel (1983) voor de naoorlogse jaren geeft. In het hier volgende overzicht noemen we alleen de bedrijven die in twee van de drie hier beschouwde jaren tot zo'n invloedssfeer gerekend kunnen worden.

Aldus gedefinieerd zou de invloedssfeer van de Amsterdamsche Bank vooral uit bedrijven uit het Indonesische segment bestaan: de Bandar cultures, de Deli Maat- 
schappij, en de Oost-Javaanse stoomtrammaatschappijen. Voorts de (katholieke) Amsterdamse handelsfirma Hagemeyer en Zwanenberg-Organon uit Oss.

De invloedssferen van de Escomptobank en de NIHB liggen vanzelfsprekend ook in het Indonesische segment, met onder andere de Portland Padang Cement Maatschappij en de handelsfirma Reiss respectievelijk de ANIEM, de Javaasche Cultuurmaatschappij en de te Batavia gevestigde cultuurmaatschappij Pasir Nangka. Deze laatste behoren in 1962 tot de invloedssfeer van de Rotterdamsche Bank die dan de NIHB heeft overgenomen. In dat jaar zijn Philips en Unilever geen onderdeel meer van haar invloedssfeer. Deze wordt gecompleteerd door drie handelsfirma's (Internatio, Stokvis en Tels) en de Rotterdamse rederij van Van Nievelt \& Goudriaan.

De invloedssfeer van de Twentsche Bank is het geringst, met slechts twee industriële bedrijven uit het Nederlandse segment.

De NHM, die telkens de hoogste rush heeft en met het grootste aantal bedrijven door directielijnen verbonden is, heeft ook de grootste invloedssfeer. De verschuiving daarvan illustreert de heroriëntatie van de NHM van intermediaire bedrijfstakken als handel en scheepvaart naar de industrie. Demka, Naarden en Werkspoor behoren pas vanaf 1954 tot de invloedssfeer van de NHM. De handelsfirma Lindeteves en het Zeehaven- en Kolenstation Sabang daarentegen juist tot en met 1954. Er zijn zes bedrijven uit onze steekproef die er in alle drie de jaren toe behoren: de KJCPL, De Kondor, Müller, NISHM, de Soerabaja Droogdok Maatschappij en de Verenigde Javasche Houthandel Maatschappijen.

Geconcludeerd kan worden dat de beide Indonesische handelsbanken er niet in slagen de verbindingen met bedrijven uit het Nederlandse segment te activeren. Dat lukt wel aan de Amsterdamsche Bank en de NHM, waarvan de eerste aanvankelijk verrassend veel directielijnen met bedrijven uit het Indonesische segment kent, en verreweg de minste naar het binationale segment. Opvallend veel directielijnen naar het binationale segment kent daarentegen behalve de NHM de Rotterdamsche Bank, wier betrokkenheid op het Nederlandse segment juist nog enigszins afneemt. De Twentsche Bank ten slotte doet zich kennen als de bank die ruimschoots het meest op het Nederlandse segment gericht is.

Een samenvattend beeld van de structuur(veranderingen) in het netwerk van dubbelfuncties tussen op Indonesië georiënteerde bedrijven geeft grafiek 4. Alle lijnen die in 1946, 1962 en ten minste twee van de tussenliggende onderzoeksjaren een gewicht van drie of meer hebben, noemen we permanent. Veranderingen in dit netwerk doen zich dan voor als verbroken en als nieuwe lijnen op dit niveau. Aanvullende analyses op de lijnen met een gewicht van twee of meer bevestigen onze hieronder geschetste bevindingen in grote lijnen.

De grafiek is beperkt tot de grootste component in het deelnetwerk met zware lijnen, dat wil zeggen drie of meer gemeenschappelijke functionarissen. De andere componenten bestaan uit een veel kleiner aantal bedrijven en zijn veelal specifiek voor een sector. Zo zijn er in 1946 buiten de grote zware component componenten van zes (Deli), twee en nog eens twee cultuurmaatschappijen, van een consortium van vier stoomtrammaatschappijen op Oost-Java, en van Calvé en KNGS in het 
Grafiek 4: Structuurveranderingen in het netwerk van directielijnen

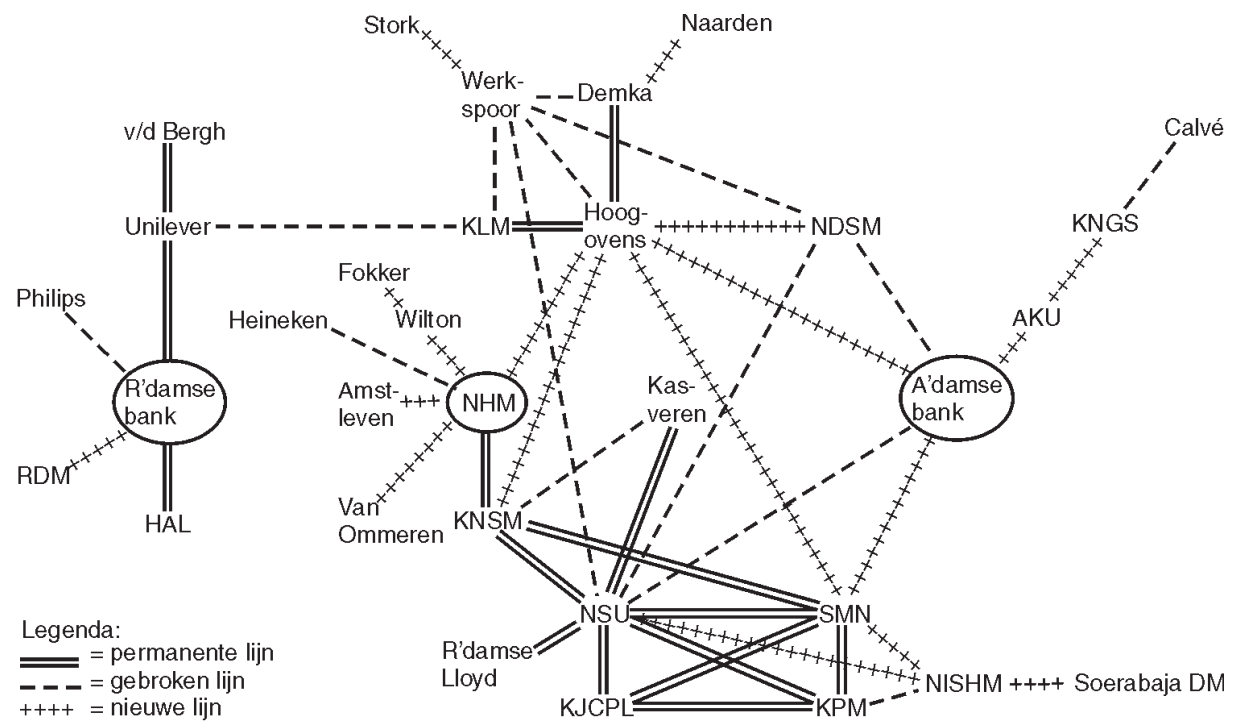

Nederlandse segment. Ook de vierde grote handelsbank, de Twentsche Bank, blijft veelal buiten de grote zware component. Binnen deze grote, zware component groeit de inbreng van bedrijven uit het Nederlandse segment van 10 tot 16 terwijl de inbreng uit het binationale segment afneemt van 9 tot 8 .

In de aldus geconstrueerde grafiek zijn drie stabiele groepen te onderscheiden:

1. een van oorsprong in de koloniale scheepvaart actieve Amsterdamse groep, waar ook de NHM aan hangt;

2. een Rotterdamse industriële groep (Unilever en Philips) waarin de Rotterdamse Bank centraal staat;

3. een groep van KLM, Hoogovens en verdere metaalindustrie, ten dele gelieerd aan de staat.

Het meest opmerkelijk is de heroriëntatie van de NHM in de jaren vijftig. De van oorsprong meest koloniale van de Nederlandse handelsbanken blijft (via de KNSM) met de Amsterdamse scheepvaart verbonden, maar de intensiteit van die verbindingen neemt af. In plaats daarvan knoopt de NHM zwaardere bestuurlijke relaties aan met de Hoogovens, de Rotterdamse scheepswerf van Wilton-Feijenoord en de Rotterdamse reder Van Ommeren, die niet op Indonesië voer. Ook voor de Amsterdamsche Bank is, zij het wat minder geprononceerd, een verlegging van de lijnen van de scheepvaart en scheepsbouw naar de industrie zichtbaar.

Daarmee hangt uiteraard samen de toenemende centraliteit van de Hoogovens in de grafiek. Beide Amsterdamse handelsbanken, de NHM en de Amsterdamsche Bank, ontwikkelen een intensieve relatie met dit trekpaard van de Nederlandse industrialisatie in de jaren vijftig. 


\section{Conclusie}

De scheiding der wegen voor de op Ind(ones)ië georiënteerde bedrijven heeft zich gefaseerd voltrokken. Gedurende het eerste deel van onze onderzoeksperiode, het decennium na de oorlog en de soevereiniteitsoverdracht, hebben veel in Indonesië actieve bedrijven nog de hoop gekoesterd dat zij deel zouden blijven uitmaken van de nieuwe Indonesische economie. De bedrijven die aan de archipel zelf gebonden waren, zoals de cultuur- en stoomtrammaatschappijen stevenden nochtans op hun ondergang af. Die ondergang voltrok zich in het tweede deel van onze onderzoeksperiode, tussen 1957 en 1963. Uit interviews die onder meer Baudet met een aantal van deze koloniale ondernemers gevoerd heeft, blijkt een combinatie van motieven voor hun blijvende verbondenheid met de archipel. Een mengeling van historische sentimenten met de inschatting dat vooralsnog het nieuwe Indonesië niet buiten het Nederlandse bedrijfsleven zou kunnen, bracht juist deze ondernemers ertoe om al vroeg een realistische koers tegenover het nieuwe bewind van Soekarno te voeren. Dat deden zij soms al vóór de soevereiniteitsoverdracht van 1948. Daarbij toonden zij in het bijzonder een groter realisme dan de in Nederland gevestigde Indische ondernemersorganisaties en de meeste Nederlandse politieke partijen. Herbert Cremer (1873-1951), de zoon van oud-Minister van Koloniën J.T. Cremer en directeur van de Deli Maatschappij van 1916 tot 1950, was de laatste van deze grote koloniale ondernemers. Ook in het Interbellum is hij 'koploper' (zie de dissertatie van Taselaar, 1998: 54). Het leidde ertoe dat de cultures nog enige tijd konden profiteren van de naoorlogse en Korea-hausse. Voorzover de ex-koloniale ondernemers hun bedrijven elders in de ontwikkelingslanden wilden voortzetten, hadden echter slechts weinigen succes.

De minder aan Indonesië gebonden bedrijven in de handel en scheepvaart, zijn er gemiddeld genomen beter in geslaagd de dans van nationalisatie c.q. liquidatie te ontspringen. Uit de netwerkanalyses blijkt hoe zij gaandeweg integreren met het Nederlandse bedrijfsleven in engere zin. Zij profiteerden mee van de Nederlandse naoorlogse industrialisatie en de geleidelijke totstandbrenging van een Europese markt. Die heroriëntatie blijkt bij uitstek uit de veranderende positie van enerzijds de Nederlandsche Handelmaatschappij, en anderzijds de Hoogovens. De NHM verlegt haar aandacht van de koloniale naar de continentale sectoren van het bedrijfsleven. Grafiek 4 maakt dat in abstracto duidelijk. Op een meer persoonlijk vlak blijkt de heroriëntatie van de NHM natuurlijk ook enigszins uit staat 3: Ernst Heldring (1871-1954), die de NHM door de Tweede Wereldoorlog loodste, was zichtbaar meer op handel en scheepvaart gericht dan de latere president-directeuren van de van oorsprong koloniale, grootste Nederlandse handelsbank. De Hoogovens ontwikkelden zich tot het trekpaard van de Nederlandse industrialisatie in de jaren vijftig, met een daarmee corresponderende centrale positie in het netwerk van dubbelfuncties.

Zouden we iemand als de personificatie van de herstructurering en heroriëntatie in onze onderzoeksperiode willen aanwijzen, dan zou dat Hans Max Hirschfeld (1899-1961) zijn. Hirschfeld was in tegenstelling tot het koloniaal kapitaal (Cremer) 
en het bankwezen (Heldring), een Rotterdammer, en als zodanig niet wars van overheidsinterventie. Met een vooroorlogse leerschool in Indië, en een - niet onomstreden - bijzondere positie en verantwoordelijkheid gedurende de oorlog in Nederland als secretaris-generaal van Economische Zaken, voerde hij na de oorlog tal van werkzaamheden voor de Nederlandse overheid uit, zowel in het kader van de dekolonisatie als met het oog op de industrialisatie. Het bijzondere van Hirschfeld is dat hij zich in zijn opvattingen en beleid een ware Atlanticus toonde. Het is mede aan het succes van de industrialisatie in de jaren vijftig en de opkomst van Rotterdam met zijn natuurlijke Duitse achterland te danken dat het hoofdzakelijk in Amsterdam gevestigde grote koloniale kapitaal zich na de oorlog snel hersteld heeft, zodat Nederland het verlies van Indië economisch gezien betrekkelijk eenvoudig heeft kunnen opvangen.

\section{Noten}

1. Dit artikel vloeit voort uit een onderzoeksproject van de Universiteiten van Amsterdam en Groningen, waarvan het eindresultaat werd gepubliceerd in Baudet, Fennema e.a. (1983). Een uitgebreide verantwoording van de netwerkanalyses is te vinden in Nobel (1983). De verwoorde opvattingen en conclusies zijn die van de auteurs en niet noodzakelijk die van hun huidige instelling. Correspondentie aan eerste auteur op JNBL@CBS.NL en aan de tweede auteur op M.Fennema@uva.nl.

2. Kuitenbrouwer en Schijf (1998: 72) wijzen erop dat Colijn en Deterding, met de koloniale topbankier Van Aalst, niet uit de rijen van adel en patriciaat afkomstig waren maar homines novi waren. Taselaar (1998: 93) rekent dezelfde drie tot de self-made men die het Indische bedrijfsleven in Nederland rijk was. En koploper (qua functietal) Herbert Cremer was wel patriciër maar alleen als zoon van een nouveau riche.

3. Het kan natuurlijk ook anders. Een matrix met bedrijven in de kolommen, personen in de rijen en functies van personen in bedrijven in de cellen is ook een graaf, te weten een bipartite graaf. En vanuit deze bipartite graaf kan ook een personennetwerk worden afgeleid, de dual van het bedrijvennetwerk. Uit staat 3 valt eenvoudig af te leiden dat Herbert Cremer in 1946 in dit netwerk vaker M.C. Koning (bij de Amsterdamsche Bank, NSU en Werkspoor) dan Ernst Heldring (bij NSU) ontmoette. Een voorbeeld van een meer kwalitatieve personennetwerkstudie is Van den Berge en Fennema (1985) naar verwantschapsstructuren in de financieel-economische elite.

4. Voor deze grafiek is de sectorindeling van tabel 1 licht vereenvoudigd om bedrijven eenduidig aan één sector toe te rekenen. Zowel de handels- als de scheepvaartsectoren zijn samengevoegd. De overige binationale ondernemingen zijn op basis van zwaartepunt toegedeeld.

\section{Literatuur}

Baudet, H. (1983). Ondernemen in Indonesië na de Tweede Wereldoorlog. In H. Baudet, M. Fennema e.a., Het Nederlands belang bij Indië (pp. 136-175). Utrecht: Spectrum

Baudet, H. \& Carrière, R.C. (1970). Het Nederlands bedrijfsleven in Nederlands-Indië/ Indonesië. Oost-west, 9/2, 65-70.

Baudet, H., Fennema, M. e.a. (1983). Het Nederlands belang bij Indië. Utrecht: Spectrum. 
Berge, T. van den, \& Fennema, M. (1985). Verwantschapsstructuren in de financieeleconomische elite. Sociologisch Tijdschrift, 11/4, 727-751.

Brand, W. (1963). Heroriëntatie van vroeger in Indonesië werkende Nederlandse bedrijven. In: H. Baudet (red.), Handelswereld en wereldhandel - honderd jaren Internatio. Rotterdam: Internatio.

Broek, J.O.M. (1942). Economic development of the Netherlands Indies. New York: Institute of Pacific Relations.

Derksen, J.B.D. (1946). De economische betekenis van Nederlandsch-Indië voor Nederland met cijfers en statistieken toegelicht. In: W.H. van Helsdingen \& W. Hoogenberk (red.), Hecht verbonden in lief en leed. Amsterdam: Elsevier.

Derksen, J.B.D. \& Tinbergen, J. (1945). Berekeningen over de economische betekenis van Nederlandsch-Indië voor Nederland. Maandschrift CBS, 10/12, 210-218.

Dooley, P. (1969). The interlocking directorate. American Economic Review, 59, 314-323.

Fennema, M. \& Schijf, H. (1979). De analyse van dubbelfuncties: theorie en methode. Cahiers voor de Politieke en Sociale Wetenschappen, 1/3, 11-59.

Gorter, W. (1964). Enkele gedachten over de economische betekenis van het verlies van Indonesië. De Economist, 108/10, 641-658.

Levine, J. (1972). The sphere of influence. American Sociological Review, 37, 2-27.

Kuitenbrouwer, M. \& Schijf, H. (1998). The Dutch colonial business elite at the turn of the century. Itinerario, 22/1, 61-86.

Nobel, J.R. (1983). Verlegde Lijnen. Mededelingen 32. Amsterdam: FSW-A van de UvA.

Nobel, J.R., Fennema, M. \& Koopman, M. (1983). Het netwerk. In H. Baudet, M. Fennema, e.a. (pp. 176-206).

Scott, J. (1979). Corporations, classes and capitalism. London: Hutchinson.

Scott, J. (2000). Social network analysis. Londen: Sage Publications.

Schijf, H.(1993). Netwerken van een financieel-economische elite. Personele verbindingen in het Nederlandse bedrijfsleven aan het eind van de negentiende eeuw. Amsterdam: Het Spinhuis.

Smit, D.C. (1963). Een eeuw licht en kracht. Rotterdam: OGEM.

Stokman, F.N. \& van Veen, F.J.A.M. (red.), (1981). GRADAP user's manual. Amsterdam, UvA.

Sweezy, P. (1953). The present as history. New York: Monthly Review Press.

Taselaar, A. (1998). De Nederlandse koloniale lobby. Ondernemers en de Indische Politiek, 1914-1940. Leiden: Research school CNWS Universiteit van Leiden.

Useem, M.J. (1979). The social organization of the American business elite and participation of corporation directors in the governance of American institutions. American Sociological Review, 44, 553-572.

Wasserman, S. \& Faust, K. (200o). Social network analysis. Methods and applications. Cambridge: Cambridge University Press. 



\title{
De internationalisering van de financieel- economische bestuurselite
}

\author{
Eelke Heemskerk
}

\section{Inleiding}

Steeds vaker hebben buitenlanders zitting in het bestuur van een Nederlandse onderneming. Niet alleen als topmanagers in de Raad van Bestuur, maar ook als toezichthoudend commissaris moeten Nederlanders het veld ruimen. In 2002 heeft de helft van de topmanagers en 40 procent van de toezichthouders van de grootste beursgenoteerde ondernemingen ${ }^{1}$ een buitenlandse nationaliteit (Hay \& Towers Perrin, 2003).

De internationalisering van de Nederlandse financieel-economische bestuurselite staat niet op zich. De grootste beursfondsen halen al 79 procent van hun verkoop uit het buitenland. Belangrijker nog is de positie van buitenlandse aandeelhouders. Gemiddeld is 64 procent van het aandelenkapitaal van deze bedrijven in buitenlandse handen. Daarmee is Nederland een koploper; het Europese gemiddelde ligt op respectievelijk 61 procent voor de verkoop en 31 procent voor het aandelenkapitaal (Heidrick \& Struggles, 2003). De internationalisering van de top van het Nederlandse bedrijfsleven loopt parallel met een verandering in het sturingsmodel van de Nederlandse economie. Het sturingsmodel is de specifieke samenstelling van onderlinge afspraken, ongeschreven regels en wettelijke voorschriften die samen bepalen hoe grote bedrijven worden bestuurd (zie Heemskerk e.a., 2002). Het behelst de verhoudingen en onderlinge relaties tussen bedrijven, kapitaalverschaffers, werknemers, overheid en maatschappij. Het wettelijk kader van het Nederlandse sturingsmodel wordt gevormd door het structuurregime. Onder dit regime neemt de Raad van Commissarissen een groot aantal van de bevoegdheden van aandeelhouders over, zoals het goedkeuren van de jaarrekening en het aanstellen van nieuwe bestuurders en commissarissen (coöptatie). De toezichthouders dienen het belang van de onderneming in het geheel in ogenschouw te nemen en niet alleen dat van de aandeelhouders.

Met de toenemende internationale samenstelling verandert het karakter van het Nederlandse bedrijfsbestuur aanzienlijk. Zo verdrijft Engels het Nederlands als de 
voertaal in de bestuurskamer. Traditionele normen en mores maken plaats voor internationaal geaccepteerde gedragscodes (de zogenoemde 'codes of best practices') en in dat proces lijkt ook een zekere mate van anomie te bestaan. In de afgelopen jaren zijn diverse gevallen van fraude en mismanagement geconstateerd. In de meeste gevallen hebben topmanagers de financiële situatie van hun bedrijf te rooskleurig voorgesteld, teneinde een hoge beurskoers te behouden. De commissarissen blijken nauwelijks in staat hun toezichthoudende functie goed uit te oefenen. Gedeeltelijk komt dit voort uit een structurele informatieachterstand op de topmanagers, maar ten dele zijn zij zelf te weinig onafhankelijk of assertief genoeg om in te grijpen. Zo beschreef oud-premier Lubbers zijn eigen positie bij het door voorkennis geteisterde bestuur van het uitzendbureau Content als 'commissaris op afstand'.

De discussie rondom besturing en toezicht van het grote bedrijf (de corporate governance) is daarom heden ten dage uiterst actueel. (Zie voor een uitgebreide historische verhandeling over het begrip corporate governance en Nederlandse bedrijfsbesturing de studie van Frentrop, 2002). Al in 1997 stelde het bedrijfsleven een 'code of best practices' op (veertig aanbevelingen, zie Peters, 1997) maar dit heeft niet geleid tot de zelfregulering waar men op hoopte. Een nieuwe commissie, ditmaal onder leiding van Morris Tabaksblat, bereidt dit jaar een nieuwe, uitgebreidere code voor. In dit artikel wordt 'corporate governance' in een ruimere zin besproken dan doorgaans gangbaar is. Het onderwerp is niet het individuele bedrijf, maar de samenstelling en onderlinge verbanden tussen de Nederlandse bestuurskamers in het licht van de veranderingen in het sturingsmodel. Deze sociologische benadering geeft de mogelijkheid om zelfsturing en coördinatie binnen de bestuurselite op een nieuwe manier te benaderen.

De meeste aanpassingen in het Nederlandse sturingsmodel hebben een sterk technisch karakter. Beschermingsconstructies, stemprocedures op aandeelhoudersvergaderingen en financieringsmethoden zijn slechts voor specialisten interessant. De toegenomen bezoldiging van topbestuurders en toezichthouders kan echter sinds enkele jaren rekenen op een forse publieke verontwaardiging. Volgens betrokkenen - bestuurselite en werkgeversvertegenwoordigers - zijn de stijgende beloningen het gevolg van de situatie op de internationale arbeidsmarkt. Om goede bestuurders te behouden moeten ze immers goed betaald worden en het groeiend aantal buitenlandse bestuurders bewijst het bestaan van deze markt. Een tegenovergestelde mening werd in 1997 door toenmalig Premier Kok verwoord toen hij sprak van 'exhibitionistische zelfverrijking' door bestuurders. De bestuurselite zou zó ver van de Nederlandse maatschappij verwijderd zijn dat ze de commotie om hun salaris niet eens meer begrijpen.

Er is blijkbaar sprake van een discrepantie tussen de opvattingen van de bestuurselite en de publieke opinie. Kan er inderdaad worden gesproken van een internationale markt van bestuurders, waar slechts met de juiste (hoge) beloning goede bestuurders kunnen worden behouden? Of is de toegenomen bezoldiging van bestuurders het resultaat van een overgenomen 'manier van doen'; neemt de Neder- 
landse financieel-economische bestuurselite een Anglo-Amerikaanse praktijk over zonder dat daarvoor een economische noodzaak bestaat? Deze vragen staan centraal in dit artikel.

De opzet is als volgt. In de volgende paragraaf worden eerst het concept sturingsmodel en de Anglo-Amerikaanse en Rijnlandse variant besproken. Tegen deze achtergrond volgt een beschrijving van de Nederlandse bestuursgemeenschap en de veranderingen in de structuur hiervan. Aansluitend komt de toenemende stijging van de bezoldiging van de bestuurselite aan de orde als voorbeeld van verandering. Daarna wordt het aandeel van buitenlanders in het Nederlandse bedrijfsbestuur en de opkomst van transnationale bestuursnetwerken nader geanalyseerd. Om de claim van de opkomende arbeidsmarkt voor bedrijfsbestuurders te testen is voorts voor alle buitenlandse topmanagers in de grootste beursgenoteerde bedrijven bekeken hoe zij zijn gerekruteerd. Het blijkt dat de toestroom van buitenlandse managers vooral voortkomt uit buitenlandse acquisities. Daarnaast is de internationale interne arbeidsmarkt bij met name de multinationals een grote bron van niet-Nederlandse topmanagers. Slechts een gering aantal topmanagers werd extern gerekruteerd. In de laatste paragraaf komen de implicaties van deze bevindingen aan de orde.

\section{Sturing in de economie}

De econoom Michel Albert, destijds bestuursvoorzitter van een grote Franse verzekeraar, introduceerde in 1991 het onderscheid tussen het Anglo-Amerikaans en Rijnlands model van kapitalisme (Albert, 1991). In het Rijnlands kapitalisme bestaan bankgeoriënteerde, samenhangende clusters van bedrijven ('business groups') waar de nadruk ligt op hechte samenwerking en directe coördinatie. Bedrijven onderhouden duurzame relaties met elkaar. Deze bindingen tussen bedrijven stoelen op de gedachte dat de coördinatie van economisch handelen via het marktmechanisme moet worden aangevuld met meer directe vormen van coördinatie (Windolf, 2002).

Een veelgebruikte en sterke verbinding is de dubbelfunctionaris. Bestuurders bezetten regelmatig meer dan één functie. Zo kan een bank ter bescherming van een krediet één (of meerdere) topmanagers een toezichthoudende functie bij de cliënt laten vervullen (zie over de verschillende functies van deze verbindingen Mizruchi, 1996). Hoewel niet alle dubbelfuncties worden gebruikt voor dergelijke directe coördinatie, leggen de dubbelfunctionarissen altijd netwerkverbindingen tussen de verschillende besturen van de grootste bedrijven. Daarmee dragen ze bij aan de samenhang in de bestuurselite. De onderlinge relaties en ontmoetingen fungeren als construerend element van een bedrijfsgemeenschap. Als zodanig zijn deze relaties onderdeel van het structurele aspect van het sociaal kapitaal (zie Bourdieu, 1985; Coleman, 1988) van het bedrijfsleven. Sociaal kapitaal wordt wel omschreven als smeermiddel voor de economie. Bedrijven functioneren niet als onafhankelijke actoren, maar zijn ingebed in sociale netwerken (Grannovetter, 1985). Die netwer- 
ken kunnen worden gebruikt om, buiten de markt om, economische processen te coördineren en daarmee transactiekosten te verminderen.

In het Rijnlands sturingsmodel wordt de coördinerende werking van de dubbelfuncties regelmatig aangewend. Een hecht verbonden bestuursnetwerk verwijst in deze optiek naar een sturingssysteem waar beïnvloeding en coördinatie loopt via directe bemoeienis: stemverheffing of 'voice' (Hirschman, 1970). Regelmatig bezetten topmanagers commissariaten bij andere grote bedrijven. Toezichthouders en topmanagers zijn zo als groep nauwelijks van elkaar te onderscheiden. Dit draagt bij aan de autonome positie van de bestuurselite.

De Rijnlandse economieën kennen ook een hoge mate van geconcentreerd eigendom. Grote aandeelhouders houden ter bescherming van hun investeringen controle op en contact met het management van het bedrijf. Ook de werknemers hebben in het Rijnlands model een stem in het bedrijfsbestuur. Zo kent Duitsland bijvoorbeeld de werknemerscommissaris en is in Nederland de ondernemingsraad een relatief belangrijke factor in het bedrijfsbestuur. Alle belanghebbenden (stakeholders) hebben in principe een bepaalde mate van inspraak en invloed in het bedrijfsbestuur.

Tegenover het Rijnlandse 'voice'-model staat het Anglo-Amerikaanse systeem. Het komt overeen met het aandeelhouderskapitalisme, waar coördinatie vooral via de markt loopt en het management louter de belangen van de aandeelhouders in ogenschouw dient te nemen. Niet 'voice', maar 'exit' domineert als sturingsmethode. Al vroeg in de ontwikkeling van de moderne bedrijfsstructuren ontstond in de Verenigde Staten een sterke aversie tegen de hoge mate van vervlechting tussen banken en industrie. Dit culmineerde in het eerste gedeelte van de twintigste eeuw in wetgeving omtrent concurrentiebeperkende coördinatie. Specifieke dubbelfuncties werden verboden en de functies van het bankwezen werden gescheiden in commerciële banken en investeringsbanken. In tegenstelling tot continentaal Europa heeft het bankwezen in de Verenigde Staten zich nooit als sturende sector kunnen ontwikkelen. De vrije markt werd geacht het meest effectieve coördinerend mechanisme te zijn. Bovendien was er in de Verenigde Staten slechts in beperkte mate sprake van geconcentreerd eigendom. Er waren nauwelijks grote aandeelhouders die via 'voice' hun belang kenbaar maakten, maar juist zeer veel kleinere aandeelhouders. Directe coördinatie tussen al deze kleine aandeelhouders stuitte op diverse speltheoretische belemmeringen. De enige optie voor de aandeelhouder om zijn mening over het management kenbaar te maken is weglopen: de aandelen verkopen.

Volgens de theorie van het aandeelhouderskapitalisme zal deze exitstrategie via de tucht van de markt een disciplinerende werking hebben en daarmee een oplossing bieden voor het coördinatieprobleem. De verkoop van de aandelen drukt immers de koers van het aandeel dat in een dergelijke liquide markt steeds meer als waarderingscijfer voor het management kan worden gezien. Een bedrijf met een te lage koers (ten opzichte van de werkelijke waarde) kan via de aandelenmarkt worden opgekocht door een tweede bedrijf. Om dit te voorkomen zullen de managers 
een zo hoog mogelijke aandelenkoers nastreven, wat samenvalt met het belang van de kapitaalverschaffers. Dit disciplineringsmechanisme wordt aangeduid als de markt voor bedrijfscontrole.

De status van een dubbelfunctie is in het Anglo-Amerikaanse model enigszins ambigu. De bestuurders, de voorzitters in het bijzonder, krijgen een status van een ster toegewezen. Hun persoonlijke inspanning is direct verbonden met het wel en wee van het bedrijf (getuige de bonussen die aan bedrijfsprestaties zijn gekoppeld). De samenstelling van het bestuur maakt dan ook in toenemende mate onderdeel uit van de aandeelhouderswaarde. Het vertrouwen dat een bestuurder geniet, straalt af op het vertrouwen in een bedrijf en daarmee op de beurskoers en dit vertrouwen wordt in grote mate versterkt door prestigieuze posities van de bestuurder bij andere bedrijven. Dubbelfuncties dragen zo bij aan het prestige van een bedrijf, maar staan haaks op de eisen van onafhankelijk bestuur, wat in het aandeelhouderskapitalisme een groot goed is. Dubbelfuncties zijn in dat opzicht niet alleen mogelijke verspreiders van (voor)kennis en informatie, maar vergroten ook de volatiliteit van bedrijven op de beurs. Wanneer bijvoorbeeld een bankdirecteur in zijn rol als commissaris bij een uitgever te maken krijgt met een schandaal (dat kan zowel de persoon betreffen, zoals fraude, als mismanagement door de gehele raad van de uitgever), straalt dit af op zijn 'primaire affiliatie'.

Dubbelfuncties komen dus zowel in Anglo-Amerikaanse als in Rijnlandse economieën voor. Het verschil ligt vooral in de manier waarop dubbelfuncties worden gebruikt voor directe coördinatie en in de structuur van het netwerk van dubbelfuncties. Maar naast directe beïnvloeding zijn er ook mogelijkheden voor indirecte coördinatie. De regelmatige ontmoetingen van de bestuurders leggen de basis van een gemeenschap: het old boys netwerk. Binnen dit netwerk vindt zowel sociale controle als afstemming plaats. 'There need be not explicit conspiracy', schrijft Mills, 'and certainly none that is provable. What is important is that each big producer makes his decisions on the basis of his impression of the reactions of the other big producers' (Mills, 1956: 120). Voor het netwerk van dubbelfunctionarissen werd eerder al opgemerkt 'dat door het bestaan, maar tegelijkertijd onvolledig beheersbaar zijn van vervlechtingen tussen organisaties het mesoniveau (de organisatie van organisaties) - hoe anoniem ook - eigen ordeningsprincipes kan gaan vertonen' (Wassenberg aangehaald in Fennema \& Schijf, 1985: 22). Dergelijke indirecte coördinatie kan in beide sturingsmodellen voorkomen. Zo toont onderzoek naar bestuursnetwerken in de Verenigde Staten aan dat bestuurlijke dubbelfuncties instrumenteel zijn in de verspreiding van innovatieve bedrijfspraktijken, zoals het invoeren van bepaalde beschermingsconstructies of het instellen van een investor office (Davis \& Greve, 1997).

Nederland ligt dichter tegen het Rijnlandse dan tegen het Anglo-Amerikaanse model aan (Albert, 1991; Gelauff \& Den Broeder, 1996). De coördinatiemogelijkheden binnen het bestuursnetwerk zijn hier een kenmerk van, maar ook het 'poldermodel' geeft aan dat er een voorkeur bestaat voor economische coördinatie buiten de markt om. In de afgelopen vijftien jaar is er echter een sterke druk ontstaan op 
het Nederlandse sturingsmodel om zich te ontwikkelen in de richting van het Anglo-Amerikaanse aandeelhouderskapitalisme.

\section{Bestuursnetwerken in Nederland}

In Nederland wordt het bedrijfsbestuur traditioneel gevoerd door een in sociologisch opzicht relatief gesloten groep personen (Van Heek, 1945; Vinke, 1961; Beekenkamp, 2002). Rekrutering in deze financieel-economische elite vindt plaats op basis van coöptatie. Hechte netwerken van dubbelfuncties onderbouwen de elitegemeenschap van bedrijfsbestuurders. Al sinds de opkomst van de naamloze vennootschap kent Nederland een hecht verbonden netwerk van dubbelfunctionarissen. Aan het einde van de $19^{\mathrm{e}}$ eeuw was dit nog sterk regionaal georganiseerd, maar ook toen was er al een nationale financieel-economische bestuurselite (Schijf, 1993). Gedurende de twintigste eeuw kende Nederland een nationaal georiënteerd netwerk, waar - in navolging van Duitsland - vooral banken een centrale rol innamen (zie o.a. Wibaut, 1913, Vinke, 1961, Helmers e.a., 1975, Stokman e.a., 1985; Stokman e.a., 1988). Ook in de laatste 25 jaar van de vorige eeuw kende Nederland een sterk verbonden netwerk. Bestuurders blijven verbonden in een hecht 'old boys' netwerk (Heemskerk e.a., 2002; Heemskerk e.a., 2003). Wel neemt de gemiddelde omvang van het bedrijfsbestuur af en is er een reductie in het absolute aantal dubbelfuncties waar te nemen. Het zijn met name de duurzame, sterke verbindingen die voor directe coördinatie kunnen worden gebruikt die verdwijnen. Zo delen bedrijven steeds minder vaak meer dan één bestuurder. Ook is er een afname in het aantal topmanagers die een commissarisstoel bezetten. Juist deze verbindingen zijn instrumenteel voor controle en supervisie (Mizruchi, 1996).

De banken blijven weliswaar centraal verbonden, maar het karakter van hun verbindingen is veranderd. Waar bankbestuurders in de jaren zeventig veel commissariaten hadden, is deze situatie twintig jaar later omgedraaid. In 1996 zijn het vooral topmanagers van niet-financiële bedrijven die commissaris zijn bij een bank. De bankdirecteuren gebruiken hun commissariaten niet langer om de Nederlandse economie te monitoren en aan te sturen. Tegenwoordig fungeert hun eigen Raad van Commissarissen als verzamelplaats van de 'captains of industry'.

De structurele veranderingen duiden dus op een afname van duurzame verbindingen en directe coördinatiemogelijkheden tussen bedrijven. Deze afbraak van structurele coördinatiekanalen maakt dat het Nederlandse sturingsmodel steeds meer overeenkomsten vertoont met het Anglo-Amerikaanse model. Toch weten Nederlandse bestuurders de 'scherpe kantjes' van het Anglo-Amerikaanse model af te slijpen. Een goed werkende markt voor bedrijfscontrole resulteert bijvoorbeeld in een onzekere positie voor topmanagers en toezichthouders. Slecht management wordt via dalende beurskoersen en mogelijke overnames afgestraft. Deze disciplinerende marktwerking wordt in Nederland op een aantal manieren beperkt. Ten eerste is er in veel bedrijven een grote aandeelhouder. Vooral pensioenfondsen $(18,3 \%$ van het genoteerde aandelenkapitaal) en verzekeraars $(28,9 \%)$ bezitten grote pakket- 
ten aandelen. Banken houden 8 procent van het Nederlandse aandelenkapitaal in hun bezit. Ter vergelijking, in Duitsland zijn het vooral industriële bedrijven die aanzienlijke pakketten aandelen in andere bedrijven hebben $(36,1 \%$ van al het eigendom, zie Windolf, 2002: 39). De aanwezigheid van grote aandeelhouders

bemoeilijkt een eventuele vijandige overname van het bedrijf en beperkt de werking van de markt voor bedrijfscontrole. Weliswaar kan de vrijheid van de topmanager worden beperkt indien de institutionele beleggers zich opstellen als 'active investors', maar de mate waarin dit gebeurt is moeilijk in te schatten. En als de grote beleggers hun invloed willen laten gelden, zullen ze eerder geneigd zijn dit via bilaterale contacten te doen (voice), dan via de algemene vergadering van aandeelhouders.

Ten tweede wordt de disciplinerende werking van de markt, die valt of staat met (de dreiging van) een vijandige overname, in zeer grote mate beperkt door allerhande beschermingsconstructies. Al in 1898 werd het eerste prioriteitsaandeel door KNPM (thans onderdeel van Shell) ingevoerd om een vijandige overname door de American Standard Oil van Rockefeller af te weren. Prioriteitsaandelen kennen speciale statutaire bevoegdheden, zoals het recht bindende voordrachten te doen voor het bestuur. Een andere manier om aan de invloed van aandeelhouders te ontsnappen is het certificeren van de aandelen. Niet de aandelen zelf, maar certificaten worden uitgegeven en verhandeld op de markt. De aandelen zelf, met het daarbijbehorende stemrecht, worden beheerd door een administratiekantoor. Hoewel officieel onafhankelijk, bestaat het bestuur van het administratiekantoor doorgaans ook uit bestuurders van het betreffende bedrijf. Ten slotte is er nog de zogenoemde gifpil. In het geval van een vijandige overname kunnen er (een groot aantal) nieuwe aandelen worden uitgegeven aan een bevriende partij (een ander bedrijf of 'witte ridder', werknemers, een stichting). Hiermee verwatert het aandeel en daarmee de zeggenschap van de biedende partij.

De aanpassingen in het sturingsmodel lijken dus nogal ambigu. Hechte en duurzame verbindingen nemen af, maar het netwerk van dubbelfuncties blijft bestaan. Aandeelhouderskapitalisme is in zwang, maar 'Rijnlandse' beschermingsmechanismen beperken de disciplinerende marktwerking. Naast de structurele en gecodificeerde veranderingen zijn er ook aanpassingen in het handelen van de bestuurselite. In de inleiding werd de stijgende beloning van bestuurders al genoemd als voorbeeld van veranderende normen en mores.

\section{Internationale beloningen}

De beloning van bestuurders en voornamelijk van de topmanagers is de afgelopen jaren bijzonder snel gestegen. De Volkskrant publiceert jaarlijks een overzicht van de bezoldiging van de grootste beursgenoteerde bedrijven. Ook de samenwerkende onderzoeksbureaus Hay en Towers Perrin brachten in opdracht van VNO-NCW en het Nederlands Centrum voor Directeuren de beloning van bestuurders in kaart (Hay/Towers Perrin, 2001 en 2003). Beide onderzoeken verschillen nogal in bereke- 
Figuur 1: Indexcijfers beloning 1996-2003

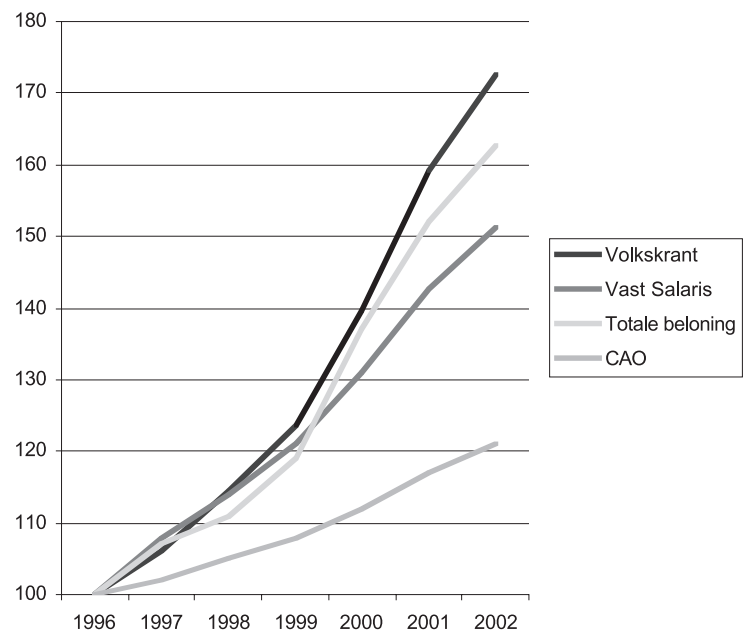

De gegevens van de Volkskrant zijn voor 1996 aangevuld met informatie uit Het Parool. Hay/Towers Perrin noteren zowel het vaste basisinkomen als het totale inkomen inclusief bonussen (short term incentives). Ter vergelijking is ook de stijging in het CAO-loon opgenomen (bron: CBS).

ningsgrondslag. Zo komt de grote stijging van 20 procent die de Volkskrant over 2001-2002 noteert voornamelijk voort uit een groot aantal hoge vertrekpremies. Het is discutabel of deze eenmalige uitkeringen bij het gemiddelde salaris dienen te worden gerekend. Aan de andere kant heeft Hay/Towers Perrin vanaf 2000 de in Nederland werkzame buitenlanders niet meer meegenomen. Ze stellen dat buitenlanders niet naar het Nederlandse loonniveau worden betaald en dus ook geen onderdeel uitmaken van de Nederlandse markt. De gegevens die het publieke debat voeden worden op die manier niet zuiver vastgesteld.

De stijging in totale bezoldiging is desalniettemin bij beide bronnen duidelijk zichtbaar. Topmanagers krijgen doorgaans naast hun vaste salaris ook een variabele bonusuitkering. Ter vergelijking is in de figuur ook de stijging in CAO-lonen opgenomen. Het vaste salaris van de bestuurselite stijgt jaarlijks minimaal twee keer zo snel als het inkomen van hun werknemers (CAO). De totale bezoldiging is minder stabiel. Zowel Hay/Towers Perrin als de Volkskrant rapporteren een hoogtepunt in 2000 met totale stijgingen van rond de 14 procent.

Het gemiddelde vaste salaris van een normaal lid van de Raad van Bestuur bedroeg in 580 duizend euro. ${ }^{2}$ Een recent international vergelijkend onderzoek laat zien dat de Nederlandse bestuursvoorzitter een goede middenpositie inneemt. De wereldwijde gemiddelde totale beloning van de bestuursvoorzitter wordt vooral beïnvloed door Argentinië (\$879.068), Mexico (\$866.831) en de Verenigde Staten (\$1.932.580) (Towers Perrin, 2002). Vice-voorzitters verdienen jaarlijks gemiddeld 662.00o euro en de voorzitter gemiddeld 723.00o euro. De totale beloning, inclusief 
het variabele gedeelte, ligt gemiddeld 1,85 maal hoger. Commissarissen verdienen gemiddeld 49 duizend euro per lidmaatschap. In Europa verdienen Franse, Italiaanse en Zweedse bestuurders minder en Duitse, Britse, Belgische en Spaanse bestuurders meer (dit geldt voor het gemiddelde over alle bestuurders, Heidrick \& Struggles, 2003).

De stijgende beloningen zouden heel goed het gevolg kunnen zijn van de toenemende internationale samenstelling van het bedrijfsbestuur. Buitenlandse bestuurders ontvangen namelijk over het algemeen hogere salarissen dan hun Nederlandse collegae. Zo kunnen er grote verschillen binnen een bestuur ontstaan, zoals bij verzekeraar Aegon, waar in 2001 de beloning van het Amerikaanse bestuurslid tweemaal zo hoog was als dat van zijn Nederlandse voorzitter. Bovendien delen de bedrijven met een zeer internationaal samengesteld bestuur relatief hoge bonussen uit.

\section{De internationale bedrijfselite}

Van 1987 tot 1997 nam volgens eliteonderzoeker Van Hezewijk het aandeel buitenlandse bestuurders toe van 4 naar 12 procent (Van Hezewijk, 2001). Voor 1999 noteert een headhunterbureau 26 procent buitenlanders in de Nederlandse bestuurskamers van de grootste beursfondsen (Heidrick en Struggles, 2001). Een van de weinige andere onderzoeken naar de internationale samenstelling van het bedrijfsbestuur beschouwt niet alleen de 25 grootste beursfondsen (AEX), maar breidt de selectie uit naar de top 45 en laat drie binationale bedrijven (Shell, Unilever, Fortis) weg vanwege hun onevenredige bijdrage. Ook dan blijft de stijging evident. In 1990 had slechts 4,6 procent van deze bedrijven een buitenlander in het bestuur, negen jaar later is dit opgelopen tot 11 procent (Heijltjes e.a., 2002). Deze cijfers duiden op een zeer snelle internationalisering van de bestuurskamers.

Om een nauwkeuriger beeld te krijgen van de bestuursinternationalisering is voor 1996 en 2002 de samenstelling van het bestuur van de grootste beursgenoteerde ondernemingen onderzocht. Daaruit blijkt dat in 1996 al een groot deel van de besturen was geïnternationaliseerd: 25 procent van de bestuursleden heeft in 1996 niet de Nederlandse nationaliteit. In tegenstelling tot hun Nederlandse collegae verzamelen de buitenlanders nauwelijks meerdere bestuursposities in Nederland. Daarom kan het zo zijn dat deze groep in totaal slechts 20 procent van alle bestuursfuncties bezet. De bovengenoemde studies onderschatten daardoor de internationale samenstelling van het Nederlandse bedrijfsbestuur. In 1996 heeft 18 procent van alle bedrijven minimaal één buitenlandse topmanager en 72 procent heeft minimaal één buitenlandse commissaris. In 2002 zijn deze cijfers alleen maar toegenomen. Van alle bestuurders van de grootste beursfondsen heeft 43 procent een buitenlandse nationaliteit. Slechts één bedrijf heeft helemaal geen buitenlandse bestuurders (het betreft het in dat jaar in de AEX opgenomen bedrijf Van der Moolen. Eind 2002 neemt een Amerikaanse directeur van een overgenomen concurrent zitting in de Raad van Bestuur). Alle andere bedrijven hebben minimaal twee buitenlandse bestuurders. 
Figuur 2: Bestuurders naar nationaliteit in 2002 en $1996(n=256)$

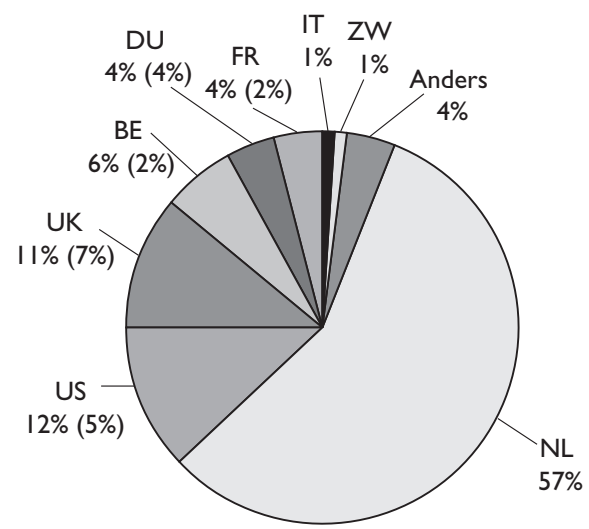

In figuur 2 is de verdeling van nationaliteiten weergegeven. Het merendeel van de buitenlanders is Amerikaans of Brits. De percentages tussen haakjes geven de situatie in 1996 weer. Toen waren de Britten met 7 procent de grootste groep onder de buitenlanders; nog geen vijf procent van de buitenlandse bestuurders was destijds Amerikaans. Ook in 2002 bezetten buitenlandse bestuurders nauwelijks meerdere functies: slechts 37 procent van het totaal. Het zijn nog steeds de Nederlandse bestuurders die met hun dubbelfuncties de top van het Nederlandse bedrijfsleven met elkaar verbinden. In de volgende paragraaf wordt bekeken of de buitenlandse bestuurders wellicht bijdragen aan het opspannen van een transnationaal netwerk.

\section{Het transnationale netwerk}

Aangezien de buitenlanders in het Nederlandse bedrijfsbestuur nauwelijks meer dan één positie hebben, dragen ze nauwelijks bij aan het opspannen van het nationale bestuursnetwerk. Diverse onderzoekers wijzen echter op het ontstaan van een internationale bestuursgemeenschap (Sassen, 1991; Van der Pijl, 1998; Sklair, 2001). Een belangrijke vraag is of de nationale bestuurselite wordt vervangen door een transnationale elite. Het grote aandeel van buitenlanders in het Nederlandse bedrijfsbestuur wijst in die richting. Een recente studie naar de dubbelfuncties tussen de grootste bedrijven ter wereld laat zien dat Nederland in het internationale bestuursnetwerk goed verbonden is. Als kleine economie was Nederland in 1983 het op vijf na best verbonden land en in 1996 met 34 verbindingen zelfs het op vier na best verbonden land (Kentor \& Jang, te verschijnen). Hoewel rechte tellingen geen inzicht geven in de structuur van het netwerk en de positie van de Nederlandse bedrijven hierin, duiden de gegevens op een hoge internationale verbondenheid van het Nederlandse bedrijfsleven.

Of er werkelijk sprake is van een geïntegreerd transnationaal netwerk is echter maar de vraag. Zo schittert de economische grootmacht Japan door afwezigheid (zie 
ook Fennema, 1982). Bovendien is de toename van de transnationale verbindingen vooral te vinden binnen Europa. Dit is, gezien de inspanningen betreffende de gemeenschappelijke markt en de daarmee gemoeide aanpassingen in wetgeving niet geheel onverwacht. De Europese bedrijfsgemeenschap is in opkomst, wat zich naast een hechter bestuursnetwerk ook uit in overlegorganen zoals de Europese Ronde tafel van Industriëlen (Van Apeldoorn, 2000). Het merendeel van de bestuursverbindingen ligt echter nog steeds binnen de landsgrenzen. De resultaten van een internationale netwerkstudie van Carroll en Fennema (2002) duiden erop dat het transnationale netwerk een 'superstructuur' is die nog steeds is gebaseerd op hecht verbonden, nationale netwerken. Bovendien tonen zij aan dat het transnationale netwerk na haar opkomst in de vroege jaren zeventig vrij stabiel is gebleven. De toenemende internationalisering leidt (vooralsnog) niet tot de desintegratie van nationale bestuursgemeenschappen en maar in beperkte mate tot een toenemende dichtheid van het transnationale netwerk. Toch duidt de instroom van niet-Nederlanders in het bedrijfsbestuur wel degelijk op een toegenomen vervlechting - en afstemming - van verschillende nationale economieën. Bovendien lijkt de instroom van buitenlandse bestuurders gelijk op te gaan met een sterke stijging in de bezoldiging. De vraag is echter nog steeds of deze stijging een gevolg is van toenemende marktwerking.

\section{De arbeidsmarkt van topmanagers}

In het model van de internationale arbeidsmarkt is de assumptie dat de grootste moeite wordt gedaan om het beste talent van de wereld binnen te halen. Het arbeidsmarktmodel is dus een meritocratisch regime. Omdat Nederland als klein land maar een zeer beperkte rekruteringsbasis heeft, moet het toptalent uit het buitenland komen, zo wordt gesteld. Om deze stelling te onderzoeken wordt hier de herkomst van de niet-Nederlandse topmanagers van de grootste beursgenoteerde bedrijven in 2002 bekeken. Tabel 1 geeft dit in een overzicht weer.

Verreweg het grootste deel van de buitenlandse topmanagers $(40 \%)$ is te vinden bij de binationale bedrijven. Zij worden gerekruteerd uit hun 'eigen' nationale deel van het bedrijf. Daarnaast blijft de interne arbeidsmarkt een belangrijke rekruteringsbasis voor het topmanagement, ook voor niet-Nederlanders. In totaal is meer dan 31 procent van de buitenlandse topmanagers afkomstig uit het eigen bedrijf. Interessant is dat $\mathbf{2 2}$ procent van de buitenlandse topmanagers via een overname in het bestuur is toegetreden. De jaren negentig kende een groot aantal grensoverschrijdende overnames. In een aantal gevallen werd met de buitenlandse onderneming ook een gedeelte van het buitenlandse bestuur overgenomen. De buitenlandse bestuurders worden voor hun medewerking in het tot stand brengen van de overname beloond met een mooie positie. Slechts 6,6 procent van de topmanagers is extern gerekruteerd. De internationale samenstelling van het Nederlandse bedrijfsbestuur heeft heel andere wortels dan een internationale arbeidsmarkt voor bedrijfsbestuurders. 
Tabel 1: Niet Nederlandse topmanagers $(n=45)$

\begin{tabular}{lrlll}
\hline Herkomst & Totaal & Percentage & Recrutering \\
\hline Bestuurder in binationaal bedrijf $*$ & 18 & 40 & \\
\hline $\begin{array}{l}\text { Topmanager overgenomen bedrijf } \\
\text { Vanuit eigen bedrijf }(>5 \text { jaar werkzaam) }\end{array}$ & 10 & 22,2 & Acquisitie \\
\hline Vanuit buitenlandse dochter & 9 & 20 & Interne arbeidsmarkt \\
\hline Vanuit ander bedrijf & 3 & 6,6 & Externe arbeidsmarkt \\
\hline
\end{tabular}

* Deze groep bevat ook de Gucci Groep en CMG. Hoewel deze bedrijven geen binationale structuur hebben, hebben zij de facto een binationaal karakter.

\section{De binationale bedrijven in Nederland}

Het merendeel van de buitenlandse bestuurders is te vinden bij de binationale bedrijven. Deze bedrijven hebben een gemengd bestuur, met bestuursleden uit beide 'moederlanden'. Het binationale bedrijf is al sinds lange tijd een bekend verschijnsel in Nederland. In 1907 gingen de concurrerende olietransporteurs Shell Trading en het Nederlandse Koninklijke Olie samen in de Koninklijke Nederlandse/Shell Groep. Unilever ontstond in 1930 uit de fusie tussen de Margarine Unie en het Britse Lever. Gedurende de twintigste eeuw zijn er nog enkele pogingen gedaan om binationale bedrijven op te zetten, vooral met Duitse bedrijven. Maar zowel de samenwerking tussen staalbedrijven Hoogovens en Hoesch, als tussen de vliegtuigbouwers VFW en Fokker (1969-1980) bleek niet duurzaam. Het huidige Akzo-Nobel heeft weliswaar gedeeltelijk Duitse wortels, maar al sinds lange tijd geen binationale structuur meer. De aanwezigheid van deze binationale bedrijven verklaart dat Nederland in het transnationale netwerk weliswaar meer verbindingen heeft gekregen, maar al in 1983 zeer goed verbonden was. In de jaren negentig vinden er weer een aantal nieuwe grensoverschrijdende fusies plaats. Zo sloot in 1991 de Belgische verzekeraar AG Groep zich aan bij het een jaar ervoor gefuseerde bank-verzekeringsbedrijf AMEV-VSB (thans Fortis) en ging in 1993 uitgever Elsevier samen met het Britse Reed. De Britse automatiseerder CMG vond zijn grootste markt in Nederland en werd de facto een binationaal bedrijf. Ten slotte fuseerde in 1999 Hoogovens met British Steel, maar of deze combinatie levensvatbaar is moet nog blijken; de recessie in de Britse staalindustrie leidde recentelijk tot een hoogoplopend dispuut tussen Britse topmanagers en Nederlandse toezichthouders over de verkoop van de hoogovens in IJmuiden. De rechter besloot uiteindelijk ten gunste van de Nederlandse Raad van Commissarissen, die volgens het Nederlandse sturingsmiddel immers niet 
enkel naar het belang van de aandeelhouders (het Britse moederbedrijf), maar ook naar het belang van de stakeholders moet handelen. Deze nieuwe binationale bedrijven zorgen voor aanwas van buitenlandse bestuurders.

\section{Toegenomen acquisitie}

De nieuwe binationale bedrijven zijn het resultaat van fusies tussen min of meer gelijkwaardige partners, maar in vele gevallen werden buitenlandse bedrijven door een Nederlands bedrijf overgenomen en ingelijfd. Veel van de huidige buitenlandse bestuurders in Nederland ( 22 procent) zijn via een dergelijke overname Nederland binnengekomen. Het topmanagement van de overgenomen partij wordt voor zijn medewerking aan de overname beloond met een nieuwe, zeer goedbetaalde topfunctie. Zij verdienen het meest van alle buitenlandse bestuurders: gemiddeld 130.000 euro meer dan de buitenlandse bestuurders van binationale bedrijven en 235.000 euro meer dan de buitenlandse bestuurders die op een interne arbeidsmarkt gerekruteerd zijn. Deze 'overnamebonus' is een belangrijke motor achter de stijgende bezoldiging van bestuurders in Nederland.

De drijvende kracht achter de toenemende acquisities is de onderwerping van Nederlandse bedrijven aan het Anglo-Amerikaanse sturingsmodel. Eind jaren tachtig en gedurende de jaren negentig gaan Nederlandse bedrijven zich in toenemende mate op de aandelenmarkt richten als bron van nieuw kapitaal. Daarmee wordt aandeelhouderswaarde een belangrijk onderwerp in de bestuurskamers. Bovendien ambiëren steeds meer bedrijven een notering aan bijvoorbeeld de Amerikaanse aandelenbeurs om toegang te krijgen tot internationale kapitaalstromen. Om de aandeelhouders tevreden te houden, moet het bedrijf groeien. De kleine thuismarkt biedt wat dat betreft weinig soelaas en vele grote Nederlandse ondernemingen doen buitenlandse acquisities. Vooral Amerikaanse ondernemingen waren in trek. Van de twaalf Amerikaanse bestuurders hebben er acht via acquisities een Nederlandse bestuurszetel veroverd. Deze stoel hebben ze niet hoeven te bevechten op een internationale arbeidsmarkt, maar is hun aangereikt als overnamebonus. Illustrerend is de opmerking van een Amerikaans lid van de Raad van Bestuur van Ahold, één van de personen die via een overname in het Nederlandse bestuur is terechtgekomen.

Toen de Nederlanders ons vertelden dat ze [...] het zittende management de besluiten zouden laten nemen, moesten we daar om lachen. Als Amerikanen een bedrijf overnemen, zetten ze hun eigen management neer (De Vos, 2001).

\section{De interne internationale arbeidsmarkt}

Naast de binationale bedrijven en de acquisities als verklaring voor de instroom van niet-Nederlanders, is er wel degelijk een internationale arbeidsmarkt. Deze bevindt zich echter binnen de multinationale Nederlandse ondernemingen. De interne 
arbeidsmarkt draagt voor 33 procent bij aan de instroom van buitenlandse bestuurders. Van de buitenlandse bestuurders heeft 22,1 procent voor zijn huidige positie een buitenlandse dochter of businessunit geleid. Ongeveer 10 procent van de buitenlandse bestuurders was al minimaal vijf jaar werkzaam in het Nederlandse bedrijf (al dan niet als bestuurslid). Van alle buitenlandse bestuurders zijn er slechts drie personen direct van een ander bedrijf gekomen. Zij zijn dus de enigen die zijn gerekruteerd op de internationale arbeidsmarkt voor bedrijfsbestuurders. Van deze drie personen zijn er twee aangetrokken als Chief Financial Officer, de derde bestuurder is door een chipfabrikant weggehaald bij de Amerikaanse concurrent. Het geringe aantal topmanagers die extern zijn gerekruteerd, hebben dus wel specifieke kennis in huis.

Deze resultaten geven aan dat de internationale markt voor bestuurders nog ver te zoeken is, ondanks de sterke mate van internationalisering. Nederlandse topmanagers zelf geloven vast in de internationale arbeidsmarkt. 'Ik zie in het buitenland verdacht veel Nederlandse managers rondlopen, al zijn het niet altijd de allerhoogste bestuurders', zo pareert de Nederlandse bestuursvoorzitter van Unilever bovenstaande argumentatie (Den Blijker \& Feenstra, 2003). Nederlanders zijn inderdaad niet zo populair als topmanagers voor buitenlandse bedrijven; op dit moment zijn alleen bij Citibank en bij British Telecom Nederlandse topmanagers te vinden.

\section{Conclusie}

De afgelopen vijftien jaar liet een aanzienlijke toename van buitenlandse bestuurders zien, zodat heden ten dage nagenoeg de helft van de bestuurders van buiten Nederland komt. Deze ontwikkeling kan men niet verklaren aan de hand van het model van de opkomende internationale arbeidsmarkt voor (top)bestuurders: slechts zes procent van de onderzochte buitenlandse topbestuurders zijn extern gerekruteerd. Naast het grote aandeel van binationale bedrijven vindt het merendeel van de overige directeuren zijn weg naar de Nederlandse bestuurskamers via de interne arbeidsmarkt van de sterk geïnternationaliseerde bedrijven. Bovendien heeft de golf van overnames tot een forse toename van buitenlandse bestuurders geleid. Nederland is in trek bij buitenlanders, wellicht vanwege de autonome positie van de managers en de minder prestatiegerichte bedrijfscultuur. Nederlandse bestuurders zelf daarentegen zijn nauwelijks te vinden in de top van buitenlandse bedrijven.

Deze internationalisering maakt deel uit van het veranderende Nederlandse sturingsmodel, wat zich zowel uit in de samenstelling als in de onderlinge relaties en de mores van het bestuur. Met de internationale samenstelling van het bedrijfsbestuur positioneren de Nederlandse bedrijven zich als 'global players' en nemen als zodanig een uitzonderingspositie in. Er is geen enkel ander Europees land waar zoveel buitenlanders een bestuurspositie hebben. Hoewel de bestuurders zich in toenemende mate schikken in het regime van het aandeelhouderskapitalisme, is het Nederlandse sturingsmodel in opzet nog sterk Rijnlands. De wettelijke grond- 
slag van het sturingsmodel, het structuurregime, bedeelt nog steeds de commissarissen, en niet de aandeelhouders de meest prominente disciplinerende rol toe. De graduele verschuiving naar het Anglo-Amerikaanse sturingsmodel staat op gespannen voet met dergelijke opvattingen over het bedrijf en zijn stakeholders. Ook weten bestuurders in Nederland zich via allerhande beschermingsconstructies afgeschermd van de disciplinering via de markt voor bedrijfscontrole. Herziening van de relevante wetgeving, zowel op Nederlands als op Europees niveau blijkt een zeer moeilijke en langdurige zaak. De Nederlandse bestuurselite heeft daarmee wel de lusten, maar niet de lasten van het Anglo-Amerikaanse systeem overgenomen. Wel hoge beurskoersen, maar niet het risico om te worden overgenomen. Wel hoge beloningen voor bestuurders, maar nauwelijks toegenomen volatiliteit van hun eigen positie.

De autonomie van de bestuurders en de veranderende opvattingen over bedrijfsbestuur (het streven naar uitbreiding en het verhogen van aandeelhouderswaarde) hebben in veel gevallen geleid tot list en bedrog. Winstcijfers werden kunstmatig opgepompt of ingedamd om buffers voor de toekomst op te bouwen en om zo investeerders een rad voor de ogen te draaien. Ook de beloningsnormering verloor de verbinding met gangbare opvattingen van weleer. De bezoldiging wordt vastgesteld door de commissarissen, die zelf deel uitmaken van de bestuursgemeenschap. In deze relatief gesloten bestuursgemeenschap, waar managers steeds vaker bezig zijn met miljardenovernames en de nadruk sterk ligt op het toevoegen van waarde aan het bedrijf, neemt de realiteitszin van de bestuurders af. De beloning wordt vastgesteld via afstemming op de 'peer group'. Zo liet de top van bankverzekeraar ING recentelijk weten een salarisverhoging van 60 procent door te willen voeren, aangezien ze achterlopen bij hun Europese concurrenten. Hier is geen sprake van marktconforme beloningsnormering (er is immers helemaal geen markt), maar van toenemende zelfverrijking door de bestuurselite. Immers, als ING zijn salaris verhoogt, stijgt het gemiddelde, waarop de peers hun bezoldiging weer zullen verhogen, enzovoort. De bezoldiging lijkt eerder een maatstaf van prestige.

De inspanningen om een grote mate van internationale convergentie te betrachten in het vaststellen van de 'best practices' bevorderen wel degelijk de transparantie van het internationaal opererende bedrijfsbestuur en daarmee wellicht de internationale economische activiteiten. De normen voor behoorlijk bedrijfsbestuur behoren evenwel overeen te komen met de opvattingen van alle 'stakeholders', los van het te hanteren disciplineringsmechanisme. Verwijzen naar een mythische markt geeft dan ook geen pas.

\section{Noten}

1. Gucci Groep en ASML hebben in het geheel geen gegevens over bezoldiging doen uitkomen. Enkele andere bedrijven rapporteren alleen geaggregeerde cijfers. Voor 89 bestuurders is informatie over zowel de vaste beloning als de totale beloning beschikbaar. Als bron zijn de jaarverslagen van over het jaar 2001 gebruikt. Deze werden in het voorjaar 2002 uitgegeven en dienen ook als bron voor de bestuurssamenstelling in 2002. 
2. Het betreft hier de bedrijven die onderdeel uitmaken van de AEX index. De Amsterdam Exchange beursindex (AEX) bestaat uit een groep van ongeveer 25 beursfondsen met de hoogste omzet van hun aandelen op de beurs. De bijdrage van een bedrijf aan het 'AEXmandje' is afhankelijk van de marktkapitalisatie van het bedrijf. De samenstelling wordt jaarlijks in februari herzien. In dit artikel spreken we over deze bedrijven als we het hebben over de top beursgenoteerde ondernemingen.

\section{Literatuur}

Albert, M. (1991). Capitalisme contra capitalisme. Paris, Éditions du Seuil.

Beekenkamp, G.G. (2002). President-Directeuren, posities en patronen. Amsterdam: Aksant.

Bourdieu, P. (1985). The forms of capital. In J. G. Richardson (ed.), Handbook of theory and research for the sociology of education. New York: Greenwood.

Carroll, W. K., \& Fennema, M. (2002). Is there a transnational business community? International Sociology, 17(3), 393-419.

Coleman, J. S. (1988). Social capital and the creation of human capital. American Journal of Sociology, 94 (Supplement), 95-120.

Davis, G. F., \& Greve, H. R. (1997). Corporate elite networks and governance changes in the 1980s. American Journal of Sociology, 103(1), 1-37.

De Vos, A. (2001). Buitenlandse managers over werken met Nederlanders. Management Team, 12.

Den Blijker, J., \& Feenstra, P. (2003). De Heren mogen best iets meer verdienen. Trouw, 21-05-2003, 11.

Fennema, M. (1982). International networks of banks and industry. Den Haag: Martinus Nijhoff Publishers.

Fennema, M., \& Schijf, H. (1984). Netwerkonderzoek onder Nederlandse elites. In J. Dronkers \& F.N. Stokman (1984). Nederlandse elites in beeld. Rekrutering, samenhang en verandering (pp. 9-27). Deventer: Van Lochum Slaterus.

Frentrop, P. (2002). Corporate governance 1602-2002. Ondernemingen en hun aandeelhouders sinds de VOC. Amsterdam: Prometheus.

Gelauff, G. M. M., \& Den Broeder, C. (1996). Governance of stakeholder relationships, the German and Dutch experience. Den Haag: Centraal Planbureau.

Granovetter, M. S. (1985). Economic action and social structure: the problem of embeddedness. American Journal of Sociology, 91(3), 481-510.

Hay/Towers Perrin (2001). Honorering raad van bestuur en directiefuncties: Hay Group \& Towers Perrin.

Hay/Towers Perrin (2003). Honorering bestuurders en directeuren in perspectief 19962002/2003: Hay Group \& Towers Perrin.

Heemskerk, E.M., Mokken, R. J., \& Fennema, M. (2002). De organisatie van het Nederlandse bedrijfsleven: Graven naar Macht 25 jaar later. Tijdschrift voor Politieke Economie, 24(1), 109-134. 
Heemskerk, E.M., Mokken, R. J., \& Fennema, M. (2003). From stakeholders to shareholders? Corporate governance networks in the Netherlands 1976-1996.

Vooruitgave beschikbaar op http://users.fmg.uva.nl/eheemskerk/publications/ stakeholderpreprint_2003.pdf of http://papers.ssrn.com/sol3/papers.cfm?abstract_id $=411580$.

Heidrick, \& Struggles. (2001). Is your board fit for the global challenge? Corporate governance in Europe. Chigaco: Heidrick \& Struggles International Inc.

Heidrick, \& Struggles. (2003). Is your board fit for the global challenge? Corporate governance in Europe. Chigaco: Heidrick \& Struggles International Inc.

Heijltjes, M. G., Olie, R., \& Glunk, U. (2002). Board internationalization and the multinational company. Submission for the Second Conference of the European Academy of Management: Innovative Research in Management, Stockholm, May 9-11.

Helmers, H. M., Mokken, R. J., Plijter, R. C., \& Stokman, F. N. (1975). Graven naar macht. Amsterdam: Van Gennep.

Hirschman, A. O. (1970). Exit, voice, and loyalty: responses to decline in firms, organizations, and states. Cambridge: Harvard University Press.

Kentor, J., \& Jang, Y. S. (te verschijnen). Yes, there is a (growing) transnational business community. A study of global interlocking directorates 1983-1998. International Sociology.

Mills, C. W. (2000) [1956]. The power elite. New York: Oxford University Press.

Mizruchi, M. S. (1996). What do interlocks do? An analysis, critique, and assessment of research on interlocking directorates. Annual Review of Sociology, 22, 271-299.

NCGS. (2002). Corporate governance in Nederland 2002. De stand van zaken. Amsterdam: Nederlandse Corporate Governance Stichting.

Peters (1997). Aanbevelingen inzake corporate governance in Nederland. Amsterdam: Commissie Corporate Governance.

Sassen, S. (1991). The global city. Princeton: Princeton University Press.

Schijf, H. (1993). Netwerken van een financieel-economische elite. Personele verbindingen in het Nederlandse bedrijfsleven aan het eind van de negentiende eeuw. Amsterdam: Het Spinhuis.

Sklair, L. (2001). The transnational capitalist class. Oxford: Blackwell Publishers.

Stokman, F. N., Van der Knoop, J., \& Wasseur, F. W. (1988). Interlocks in the Netherlands: stability and careers in the period 1960-1980. Social Networks, 10, 183-208.

Stokman, F. N., Wasseur, F. W., \& Elsas, D. (1985). The Dutch network: types of interlocks and network structure. In F. N. Stokman \& R. Ziegler \& J. Scott (eds.), Networks of corporate power (pp. 112-131). Cambridge: Polity Press.

Towers Perrin. (2002). Worldwide total remuneration 2001-2002. Amsterdam: Towers Perrin.

Van Apeldoorn, B. (2000). Transnational class agency and European governance: the case of the European Round Table of industrialists. New Political Economy, 5(2), 157181.

Van der Pijl, K. (1998). Transnational classes and international relations. London: Routledge. 
Van Heek, F. (1945). Stijging en daling op de maatschappelijke ladder. Een onderzoek naar de verticale sociale mobiliteit. Leiden: E.J. Brill.

Van Hezewijk, J. (2001). De Nederlanden, let op uw Saeck. Management Team, 12, 95.

Vinke, P. (1961). De maatschappelijke plaats en herkomst der directeuren en commissarissen van de open en daarmee vergelijkbare besloten vennootschappen. Leiden: Kroese.

Wibaut, F. M. (1913). De nieuwste ontwikkeling van het kapitalisme. De Nieuwe Tijd, 18, 284-349.

Windolf, P. (2002). Corporate networks in Europe and the United States. Oxford: Oxford University Press. 


\title{
De overdracht van eliteposities binnen adellijke en patricische families gedurende de twintigste eeuw'
}

\author{
Huibert Schijf, Jaap Dronkers en Jennifer R. van den Broeke-George
}

\section{Inleiding}

Nederland kent, zoals alle moderne samenlevingen, een grote variatie aan groepen in de maatschappelijke bovenlaag. Twee van deze groepen staan officieel geregistreerd: de adel en het patriciaat. Maar de grond waarop een familie wordt opgenomen in het Nederland's Adelsboek of het Nederland's Patricaat is geheel verschillend. Globaal kan worden gezegd dat alle adellijke families zijn geregistreerd op grond van één overgeërfd kenmerk, namelijk lid zijn van de adel; patricische families daarentegen worden opgenomen op grond van persoonlijke kwaliteiten bij het vervullen van bepaalde functies over enkele generaties. Een adellijk persoon is voor buitenstaanders herkenbaar aan zijn titel (als die tenminste wordt gebruikt), leden van het patriciaat zijn aan hun naam vrijwel alleen voor insiders herkenbaar.

Over de adel zijn talrijke historische publicaties verschenen en sommige suggereren dat er geen eigen rol meer is voor de adel in de moderne samenleving, voor het patriciaat is dat minder duidelijk. Lieven (1992) en Wehler (1990) eindigen hun studies naar de Europese adel met de rampspoed van de beide Wereldoorlogen en de gevolgen daarvan voor de adel. Na de Eerste Wereldoorlog werd de aparte wettelijke status van de adel in verschillende landen afgeschaft, bijvoorbeeld in Duitsland, en daarmee verdwijnen ook de adellijke privileges. De Britse historicus Cannadine (1990) brengt zo'n these naar voren in zijn erudiete beschrijving van de achteruitgang van de Britse aristocratie gedurende de eerste helft van de twintigste eeuw. Hij biedt echter geen systematische analyse van de levensloop en carrière van een representatief aantal Britse aristocraten gedurende deze periode. Door slechts het verdwijnen van verouderd sociaal en cultureel kapitaal te benadrukken, ziet hij de soms vergaande maar succesvolle aanpassingen aan nieuwe omstandigheden door sommige leden van de adel over het hoofd. Hij onderschat daarmee het huidige belang van het gemoderniseerde sociaal en cultureel kapitaal van deze adel. Gedetailleerde beschrijvingen van afzonderlijke families bieden inzicht in dit moderniseringsproces. Uitstekende voorbeelden zijn een onderzoek naar een Duitse 
familie door Conze (2000) en dat van Schmidt (1986) naar een Nederlandse adellijke familie.

Tegenwoordig leven er nog altijd families in Duitsland en Frankrijk die zich volledig bewust zijn van hun adellijke afstamming en die nog steeds sociale bijeenkomsten organiseren in de hoop dat hun kinderen een adellijke echtgeno(o)t(e) zullen vinden. Het onderzoek van de Franse sociologe Saint Martin (1993) biedt een sociologische verklaring voor de manier waarop adellijke geslachten in staat zijn gebleken hun hoge sociale status in de moderne Franse Republiek te behouden. Zij legt daarbij de nadruk op de blijvende waarde van het symbolisch en sociaal kapitaal van de adel. Helaas lijdt haar onderzoek aan methodologische tekortkomingen. Omdat Frankrijk een republiek is, is het onmogelijk een allesomvattend of representatief overzicht van leden uit de Franse adel te verzamelen. Saint Martin moest genoegen nemen met niet-representatieve steekproeven uit twee bronnen. De eerste is de vereniging voor de Franse adel Association d'entraide de la noblesse Française (conservatief, katholiek en provinciaals); de tweede is Who is who in France, waarin bekende en succesvolle individuen zijn opgenomen. Haar resultaten zijn daarom niet representatief voor de huidige Franse adel als geheel. Niettemin dient dit onderzoek als inspirerend voorbeeld omdat bij ons weten er geen ander sociologisch onderzoek bestaat dat kan wedijveren met haar brede benadering.

Er bestaat ook nauwelijks sociologisch onderzoek waarin de adel wordt vergeleken met de hoge bourgeoisie, maar er zijn wel enkele onderzoeken van historici die het vermelden waard zijn. Hoewel zijn gegevens dezelfde gebreken vertonen als die van Saint Martin, presenteert Grange (1996) allerlei demografische karakteristieken van deze twee groepen in Frankrijk in de periode 1903-1987. Op een meer kwalitatieve wijze vergelijken ook Pinçon en Pinçon-Charlot (1996) de moderne Franse adellijke en hoge bourgeoisiefamilies met elkaar, maar zonder een vergelijkingsgroep van arme adellijke en hoge bourgeoisiefamilies. Reif (2001) publiceerde een bundel over de adel en burgerij in het twintigste-eeuwse Duitsland, maar met dezelfde methodologische gebreken.

De registratie van de tegenwoordige adel en patriciaat in het burgerlijke Koninkrijk der Nederlanden, die we zullen gebruiken in dit artikel, zijn completer dan de beschikbare gegevens voor Frankrijk of Duitsland, waar de adel traditiegetrouw veel belangrijker was. De bevindingen zouden om die reden ook een betrouwbare indicatie voor de positie van de huidige adel in andere Europese landen kunnen zijn. In dit artikel zullen wij overeenkomsten en verschillen tussen adel en patriciaat, en het eventuele voordeel daarbij, onderzoeken door systematisch te kijken naar de kans van adellijke en patricische personen op een elitepositie in de twintigste eeuw.

\section{De adel en het patriciaat}

De Nederlandse adel is altijd overwegend een bestuursadel (noblesse de robe) geweest en niet een zwaardadel (noblesse d'épée) of landadel, terwijl in België, Duitsland, Frankrijk en het Verenigd Koninkrijk de zwaardadel en landadel domineerden 
(Kuiper, 1993; Schmidt, 1986). De eerste reden voor dit verschil is dat gedurende het tijdperk van de Nederlandse Republiek, de voorganger van het Koninkrijk der Nederlanden, tussen 1580 en 1795, nieuwe benoemingen of uitbreiding van de binnenlandse adel niet mogelijk waren wegens het ontbreken van een landsheer (Israël 1995: 337-341). De Nederlandse zwaardadel telde bovendien maar weinig leden omdat officieren meestal uit het buitenland werden gerekruteerd. De positie van een landsedelman in de armere agrarische provincies was evenmin aantrekkelijk voor de vermogende burgers uit de economisch succesvolle provincies Holland en Zeeland. De tweede reden is het beleid ten aanzien van de adel in het nieuwe Nederlandse Koninkrijk in de jaren twintig en dertig van de negentiende eeuw (Bruin 1992: 125). Dit beleid was ontwikkeld om de lastige erfenis van de politieke strijd uit de late achttiende eeuw tussen de Orangisten en de Patriotten op te lossen (Schama, 1977). Er werd geprobeerd zich van de loyaliteit van de stedelijke regenten (rijke koopmannen en bankiersfamilies die in heel Nederland de steden bestuurden) te verzekeren door hen in de adelstand te verheffen.

Door deze historische achtergrond was de Nederlandse adel van 1815 tot 1997 in staat zijn status op een van de volgende vier manieren te verwerven: 1 . Verheffing (afstammelingen van niet-adellijke regentenfamilies in de steden met stemrecht vóór 1795 of individuen die zich verdienstelijk hadden gedragen in de negentiende eeuw); 2. Benoeming voor een gewestelijk ridderschap (individuen benoemd door de koning voor de gewestelijke ridderschappen gedurende de eerste helft van de negentiende eeuw; velen hiervan waren niet-edelen die al ambachtsheerlijke rechten in die provincie hadden of die al deel uitmaakten van de gewestelijke ridderschappen voor 1795); 3. Erkenning van oude Nederlandse adel (leden van de oude binnenlandse adel vóór 1795); 4. Inlijving van buitenlandse adel (leden van het nageslacht van nietNederlandse adel, die gevestigd waren in Nederland; Nederlanders verheven tot niet-Nederlandse adel door een vorst van een ander land). Nieuwe verleningen van Nederlandse adellijke titels zijn sinds het begin van de twintigste eeuw uiterst zeldzaam geworden. In 1994 is de Wet op adeldom in werking getreden met een overgangstermijn voor inlijvingen tot 1999. Erkenningen zijn nog mogelijk, maar inlijvingen alleen onder strikte voorwaarden. Verheffingen zijn slechts mogelijk voor leden van het koninklijk huis. De Nederlandse overheid meende de adel te moeten zien als een irrelevant historisch relikwie.

Adeldom voor het leven (een adellijke titel die alleen geldig is gedurende het leven van een persoon die wordt verheven) heeft nooit bestaan in Nederland, in tegenstelling tot het Verenigd Koninkrijk en België. Tot slot moet nog een andere beperking genoemd worden: zonen en dochters erven de adellijke titel van hun vader, maar een moeder kan haar adellijke titel niet doorgeven aan haar kinderen (wat, overigens, een voorbeeld is van ongelijke wettelijke behandeling van vrouwen in Nederland).

Als gevolg van het beleid van de eerste koningen in de eerste helft van de negentiende eeuw, werden leden van de heersende families uit de steden van de provincie Holland vaker beloond met de titel van jonkheer, terwijl de edelen uit de oostelijke 
provincies vaker de titel van baron verwierven. Om die reden hebben bijna alle regentenfamilies uit Amsterdam in onze steekproef de titel van jonkheer. In tegenstelling tot andere Europese staten is de titel van jonkheer dus geen aanwijzing voor een lagere sociale status dan de titel van baron. Een van de gevolgen van dit beleid was bovendien dat mensen hun lidmaatschap van de adel eerder te danken hadden aan regeringsbekwaamheid of economische competentie dan aan een adellijke achtergrond of cultuur. Om die reden weerspiegelt de Nederlandse adel een sterke bestuurlijke gerichtheid. Dit zou kunnen verklaren waarom verwijzingen naar de Nederlandse adel in het onderzoek van Lieven (1992) ontbreken. Vanwege zijn cultureel en sociaal kapitaal nemen we aan dat de bestuursadel beter in staat is zich aan te passen aan moderne tijden dan de zwaardadel of landadel.

De benoemingsregels van de Nederlandse adel vertonen een grotere gelijkenis met die van andere continentale Europese landen dan de procedures voor de Britse adel. De Nederlandse adellijke titels en de manier om die te erven (zowel binnen de oudere als de jongere takken van een adellijke familie) komen overeen met de Duitse en Franse procedures. Deze overeenkomst is terug te vinden in het feit dat het minder waarschijnlijk is dat afstammelingen van de Britse adel, als gevolg van afwijkende adellijke procedures, in de Nederlandse adel worden ingelijfd dan leden van de continentale adel.

Niet alle leden uit de 'hogere kringen' bezitten een adellijke titel. Sommige regentenfamilies, die gedurende lange tijd deel uitmaakten van het gemeentelijk, gewestelijk of nationaal bestuur, weigerden een adellijke titel te ontvangen, omdat zij geen hoge dunk hadden van zo'n titel (Bruin, 1981). Aan het einde van de negentiende eeuw noemden zij zichzelf nog steeds trots patriciërs. Andere families behoorden tot dit patriciaat omdat zij eenzelfde hoog en erkend aanzien hadden als de adel, maar om een of andere reden nooit in de adel waren verheven. Zelfs binnen één en dezelfde familie kunnen we afzonderlijke takken vinden met en zonder adellijke titel. Over het algemeen hebben families die heden ten dage tot het patriciaat behoren, ten minste drie generaties lang deelgenomen aan prestigieuze raden of overheidsfuncties of andere in aanzien staande publieke posities bekleed. Veel Nederlandse adel lijkt in posities en achtergrond dus sterk op het patriciaat. Desalniettemin is er een groot verschil tussen de leden van de adel en het patriciaat omdat alle leden van de adel officieel zijn geregistreerd, terwijl de registratie van patricische families tot op zekere hoogte arbitrair is (Bruin \& Schmidt, 1980).

\section{In tegenspraak met de moderniseringstheorie}

Sociologisch onderzoek richt zich zelden op de positie van adel of patriciaat in Europese samenlevingen in de twintigste eeuw. Onderzoek naar 'hoge' groepen, zoals adel en patriciaat, is van belang omdat hun uitzonderingspositie kan functioneren als een tegenvoorbeeld voor de vaker onderzochte algemene tendens binnen moderne samenlevingen. Anekdotische voorbeelden suggereren op zijn minst dat nog steeds tamelijk veel personen van adellijke of patricische afkomst eliteposities 
in het bedrijfsleven (vgl. Beekenkamp, 2002: 45) of bij de overheid in Nederland bekleden. Hartmann en Kopp (2001) onderzochten de invloed van sociale herkomst van 6500 ingenieurs, juristen en economen, afgestudeerd in de jaren 1955, 1965, 1975 en 1985, op hun kans tot toetreding tot de Duitse economische elite. Op ons verzoek hebben zij een nieuwe analyse uitgevoerd waarbij adellijke afkomst als extra onafhankelijke variabele is toegevoegd (in de vergelijkingen van hun tabel 5 , 2001: 449). Hoewel het percentage adellijke personen laag is $(1,2 \%)$ laat deze ongepubliceerde analyse zien dat een adellijke titel een sterker effect op het bereiken van een elitepositie heeft dan het al bestaande positieve effect van het tot een bourgeoisiefamilie behoren (persoonlijke mededeling aan de tweede auteur). Deze gegevens lijken de veronderstelling tegen te spreken dat met name adellijke afkomst zijn betekenis geheel heeft verloren in een samenleving waarin meritocratische kwaliteiten de belangrijkste factor zijn bij het bereiken van een hoge positie.

Een basisveronderstelling over de modernisering binnen de westerse samenlevingen is dat hoge posities steeds toegankelijker zijn geworden voor mensen met kenmerken gebaseerd op hun eigen prestaties. In dit opzicht zijn moderne samenlevingen gebaseerd op meritocratische eigenschappen. Onderzoekers hebben er terecht op gewezen dat gedurende de twintigste eeuw het aandeel van de adel bij de bekleders van eliteposities afneemt. Op grond van het verlies van de aparte wettelijke status en daardoor ook van de overgeërfde privileges, nemen zij aan dat een adellijke achtergrond onbelangrijk is geworden bij het verkrijgen van een elitepositie in de moderne samenleving. Dit is inderdaad het geval bij ascripted kenmerken als gender en sociale klasse (Lenski, 1984; Dronkers \& Ultee, 1995; Ganzeboom, Treiman \& Ultee, 1991) als gevolg waarvan het niveau van onderwijs belangrijker is geworden (Rijken, 1999). De eerste empirische observatie houdt echter niet noodzakelijkerwijs de tweede in. Het sociale belang van adellijke of patricische afkomst neemt alleen af als sociale omstandigheden zo dramatisch veranderen, bijvoorbeeld als gevolg van een revolutie, een nederlaag in een oorlog of een ernstige economische recessie, dat het adellijk sociaal en cultureel familiekapitaal niet langer van nut is. Zo'n snelle en dramatische verandering heeft Nederland nooit gekend. Wij nemen daarom aan dat leden van de adel - weliswaar in aangepaste vorm - nog steeds gebruikmaken van zijn specifiek symbolisch, sociaal en cultureel kapitaal en daarmee waarschijnlijk een voordeel blijven behouden boven de concurrenten uit de hoge bourgeoisie als het om het verwerven van eliteposities gaat.

Resultaten uit eerder onderzoek werpen een licht op dit aanhoudende voordeel in het verwerven van eliteposities in Nederland gedurende de vorige eeuw. Het eerste onderzoek heeft als uitgangspunt dat er in Nederland geen Ivy League universiteiten, Grandes Ecoles of een equivalent van Oxbridge bestaan, en dus geen instituties die studenten selecteren. Desalniettemin zou het Corps, de traditionele studentenvereniging, gezien kunnen worden als een institutie die studenten op andere manieren selecteert (Hillege \& Fennema, 1992; Dronkers \& Hillege, 1998), omdat het Corps zowel hiërarchisch als selectief is. Slechts een minderheid van alle universiteitsstudenten wordt lid. Dronkers en Hillige bestudeerden de kansen van 
1660 bestuursleden van deze studieverenigingen tussen 1920 en 1960 op het bekleden van een positie binnen de Nederlandse economische en politieke elites tussen 1960 en 1980. Een uitkomst is dat het lidmaatschap van de Nederlandse adel de waarschijnlijkheid dat deze bestuursleden op een gegeven moment een elitepositie bekleden, doet toenemen en dat deze kans door de tijd niet is afgenomen. Deze conclusie is opmerkelijk omdat de toegenomen kans van bestuursleden uit patricische families verdween nadat gecontroleerd werd voor de studierichting en een voorzitterschap, in tegenstelling tot de significant grotere kans voor studenten die behoren tot de Nederlandse adel. Zelfs toen de gegevens werden uitgebreid met bestuursleden van protestantse en katholieke studentenverenigingen (Dronkers \& Hillege, 1997) bleef die grotere kans voor het verkrijgen van een elitepositie bestaan onder bestuursleden die tot de adel behoren, terwijl dit voor diegenen die tot het patriciaat behoren niet het geval is. De bestuursleden van adellijke afkomst hadden net zoveel kans op een elitepositie in 1960 als in 1920, hetgeen duidelijk veronderstellingen over de gevolgen van modernisatie tegenspreekt.

Een tweede analyse is gebaseerd op een steekproef van 10529 studenten van alle Nederlandse universiteiten en Athenea Illustra (vroegere universiteiten zonder het recht een doctorstitel toe te kennen) tussen 1815 en 1935. Dronkers e.a. (1996) onderzochten welke van deze studenten tussen 1850 en 1995 hoge politieke functies of hoge posities bij overheidsinstellingen hadden verworven. De onderzoekers constateren dat lidmaatschap van de Nederlandse adel de kans vergroot om deze hoge politieke en bestuurlijke posities te verwerven. Bovendien neemt deze kans niet significant af gedurende de negentiende en twintigste eeuw. Deze resultaten komen geheel overeen met de bevindingen van het onderzoek onder leden van studentenverenigingen.

In een derde onderzoek toont Dronkers (2000) aan dat het blijvende voordeel van leden van de Nederlandse adel bij het verkrijgen van eliteposities verklaard kan worden door hun effectieve manier om zich aan te passen en het moderniseren van hun sociaal en cultureel kapitaal. Maar Dronkers besteedt in zijn analyse geen aandacht aan de beroepen en functies van het ouderlijk milieu, wat mogelijk kan leiden tot een onderschatting van de sociale achteruitgang van de adel of een overschatting van diens blijvende vermogen in het verwerven van eliteposities. Dronkers en Schijf (2002) behandelen deze ontbrekende factoren door de eigenschappen van het ouderlijk milieu toe te voegen aan de oorspronkelijke onderzoekseenheden. Maar zelfs als deze ouderlijke achtergrond wordt opgenomen, blijven de voordelen van een adellijke titel stabiel gedurende de twintigste eeuw. Dit artikel is een verdere uitbreiding van het derde onderzoek waarbij een controlegroep van niet-adellijke hoge bourgeoisiefamilies aan de analyse wordt toegevoegd.

\section{Data en hypothesen}

Informatie over de levensloop van alle leden van de Nederlandse adel wordt gepubliceerd door het Centraal Bureau voor Genealogie in Den Haag. Voor het samen- 
stellen van de verschillende edities van het Nederland's Adelsboek (de zogenaamde Rode Boekjes), gebruikt het Bureau alle beschikbare informatie over de geslachten van Nederlandse adellijke families (zie voor de oorsprong van het Adelsboek in 1903 Bruin \& Schmidt, 1980). Het Bureau steekt ook behoorlijk veel tijd en moeite in het opsporen van alle leden van een bepaalde familie, zelfs als emigratie of sociale achteruitgang de noodzaak voor het opnemen in het Nederland's Adelsboek heeft verminderd. Wij zijn van mening dat de methode van het Bureau veel completere en meer representatieve data voor deze groep heeft opgeleverd dan zelfs met de beste enquête of survey zou kunnen worden bereikt. De leden van de adel vermelden hun eventuele academische titels, beroepen en werkkring, overheidsbetrekkingen, lidmaatschap van belangrijke overheidsraden, posities aan het Koninklijk Hof, lidmaatschap van een ridderorde, en de vergelijkbare gegevens van hun echtgeno(o)t(e). Het Centraal Bureau voor Genealogie verifieert veel van deze data bij bronnen als de Staatsalmanak. Omdat alle betrokken partijen zich bewust zijn van het feit dat de verzamelde informatie bedoeld is voor publicatie, is het onwaarschijnlijk dat personen onbetrouwbare gegevens zullen leveren. Bovendien zal de sociale druk van de familie een familielid ontmoedigen een universitaire graad te vermelden die eigenlijk niet is behaald, of overheidsbetrekkingen of andere functies die in werkelijkheid niet zijn vervuld. Hoewel mensen natuurlijk eerder geneigd zijn de pieken van hun carrière te vermelden dan de dalen, zal dit onze analyse, die gericht is op eliteposities, zeker niet vertekenen. Aan de andere kant zijn we ook minder respectabele beroepsbezigheden in het Nederland's Adelsboek tegengekomen. Zo zijn bijvoorbeeld bijna alle leden van een van de oudste adellijke families in onze steekproef, die geboren zijn in de twintigste eeuw, boer, handarbeider of bekleden zij andere lage functies zonder duidelijke connectie met hun adellijke achtergrond.

Uit onze bronnen hebben wij een onderzoekspopulatie geselecteerd die bestaat uit alle personen geboren na 1899 maar voor 1951 die behoren tot een familie wiens naam begint met een letter ' $G$ ' of een tussenliggende letter tot en met 'Na'. Enkel de genealogieën van deze geslachten zijn gepubliceerd in de delen van het Nederland's Adelsboek die verschenen tussen 1993 en 2000. Ze bieden de meest recente en complete informatie over de levensloop van de zonen en dochters. We hebben niet de koninklijke familie en haar takken (waaronder De Bourbon de Parme) opgenomen vanwege hun speciale status binnen de Nederlandse samenleving. We hebben ook geen enkele later beschikbare informatie toegevoegd of weggelaten. Omdat de eerste letter van de achternaam niet verbonden is aan enig sociaal kenmerk, kan onze onderzoekspopulatie gezien worden als een aselecte steekproef van alle adel geboren tussen 1899 en 1951. Echter, het verzamelen van de data over de levensloop is niet op een en hetzelfde moment voor alle personen beëindigd: het verzamelen van informatie over individuen van wie de achternaam begint met een ' $G$ ' eindigde in 1992, terwijl data over individuen wier achternaam met een ' $M$ ' begint, verzameld werden tot het jaar 1999.

We beperken onze analyse tot personen die geboren zijn voor 1951 omdat we 
ervan uitgaan dat deze leden van de adel voldoende tijd hebben gehad om een elitepositie te verwerven. Gegeven de periode van het verzamelen van de gegevens in de gebruikte deeltjes, was een persoon geboren in 1950 van wie de achternaam met een ' $G$ ' begint 42 jaar oud op het moment van de registratie van zijn actuele beroep, terwijl een persoon geboren in 1950 met een achternaam beginnend met ' $\mathrm{Na}$ ' 49 jaar oud was. Deze jonge leeftijd zou kunnen leiden tot een onderschatting van de verkregen eliteposities voor degenen geboren in de jaren veertig, omdat de meeste personen gewoonlijk een elitepositie bereiken als ze ouder dan 50 zijn. Toch geven wij er de voorkeur aan degenen geboren tussen 1940 en 1950 in onze analyse te houden, omdat dit de eerste generatie geboren na de Tweede Wereldoorlog is. Met deze selectie volgen wij dezelfde procedure als Dronkers (2000) en Dronkers en Schijf (2002) hebben gevolgd. We hebben ook diegenen weggelaten die kwamen te overlijden voor hun veertigste verjaardag, zodat er geen onderschatting wordt gemaakt van de intergenerationele overdracht van sociaal en cultureel kapitaal. Discrepantie in sterftekansen zou een vertekening in de schatting van deze overdracht kunnen veroorzaken.

We hebben alle personen opgenomen ongeacht in welk land ze zijn geboren, leefden of stierven, omdat een adellijke titel (als een premodern kenmerk) niet afhangt van nationaliteit of geboorteplaats. Dit zou kunnen leiden tot enige onderschatting van het belang van sociaal en cultureel kapitaal van de adel, omdat we geen takken van families uitsluiten die lange tijd geleden geëmigreerd zijn en daarmee dus een groot deel van hun Nederlandse sociale netwerk en levensstijl hebben achtergelaten. Deze selecties leveren een dataset op van 113 adellijke families die 1872 personen omvat. Om hen te onderscheiden van hun ouders, noemen we ze zonen en dochters (of kinderen), wanneer ze onze analyse-eenheid zijn. We hebben weer dezelfde deeltjes gebruikt om informatie te verzamelen over de ouders, de echtgeno(o)t(e), en schoonouders van de zonen en dochters. Per definitie zijn de gegevens over de vader even compleet als die van de kinderen. De gegevens over de moeder hebben bijna dezelfde uitgebreidheid. De gegevens over de echtgenoten en echtgenotes zijn net zo uitgebreid als die over de moeders, maar ze zijn minder compleet. Het is niet altijd duidelijk of dit komt door een gebrek aan informatie of simpelweg door het feit dat kinderen ongetrouwd zijn gebleven. De gegevens over de schoonouders van de zonen en dochters zijn het minst uitgebreid, omdat we slechts de namen, academische en adellijke titels hebben. Het zou kunnen zijn dat er te weinig aangifte werd gedaan van de titels van schoonouders.

Het Centraal Bureau voor Genealogie publiceert ook het Nederland's Patriciaat (de zogenaamde Blauwe Boekjes), onze bron voor de hoge bourgeoisie. De eerste editie verscheen in het jaar 1910 (Bruin \& Schmidt, 1980) en het onafhankelijke beleid van het Bureau om een bepaalde familie op te nemen is tegenwoordig opener dan in de beginjaren. De manier waarop deze deeltjes worden samengesteld verschilt van het Nederland's Adelsboek, omdat er geen scherp omlijnde regels zijn over welke families opgenomen dienen te worden. Tegenwoordig is opname deels gebaseerd op traditie en deels op nieuwe criteria, gebaseerd op bepaalde eliteposities verkregen door 
leden van een familie. Het feit dat families in het Nederland's Patriciaat staan vermeld, biedt nog steeds een betrouwbare indicatie dat ze behoren tot de reeds lang gevestigde en traditionele hoge bourgeoisie in Nederland. Echter, enkele families met een hoge status in de samenleving zouden kunnen ontbreken. We hebben alle families genomen uit de deeltjes die gepubliceerd werden tussen 1993 en 1999. Dat is ongeveer dezelfde periode als die voor de gebruikte uitgaven van het Nederland's Adelsboek. In ieder deeltje wordt het complete geslacht van een aantal families geïnventariseerd in alfabetische volgorde. Deze steekproef omvat 78 families met in totaal 2860 leden. Niets in de manier waarop onze bron is samengesteld geeft reden om aan te nemen dat deze families afwijken van de gehele populatie van patricische families. De volledigheid en kwaliteit van de informatie over ieder persoon in deze deeltjes is precies hetzelfde als in het Nederland's Adelsboek. We zijn daarom in staat geheel vergelijkbare variabelen voor beide groepen families te gebruiken in onze analyse.

De volgende variabelen zullen worden gebruikt:

- Status, geeft aan of de zoon of dochter behoort tot een adellijke familie of tot een patricische familie.

- Decennium waarin de zoon of dochter geboren werd; dit loopt van het eerste decennium 1900-1909 tot het decennium 1940-1950.

- Tertiaire onderwijs van de zoon of dochter, zijn of haar echtgeno(o)t(e), beide ouders en schoonouders. Deze variabelen geven de universitaire of andere tertiaire onderwijsgraden weer van de zoon of dochter, zijn of haar partner, zijn of haar ouders en de combinatie van zijn of haar schoonouders. In het geval van de moeders, schoonouders en in mindere mate echtgenoten en echtgenotes, zijn deze variabelen afgeleid van hun academische titels, wat zou kunnen leiden tot een onderschatting van beroepsopleidingen. We zijn in staat het beroep te gebruiken, wat ons aanvullende informatie gaf over de hoogte van de beroepsopleidingen, voor een preciezere codering van het behaalde onderwijsniveau van de zoons of dochters en hun vaders.

- Persoonlijke adellijke titel van zonen of dochters en vaders titel. Jonkheren en ridders staan beide genoteerd als jonkheer omdat er maar weinig ridders over zijn. Behalve in de koninklijke familie en haar takken (waaronder De Bourbon de Parme) bestaan er nauwelijks hogere titels dan baron of graaf in de Nederlandse adel. De weinige gevallen met een hogere titel zijn aan de categorie 'graaf' toegevoegd. De titel van de kinderen is in bijna alle gevallen gelijk aan die van de vader. Kinderen uit het patriciaat bezitten uiteraard geen adellijke titel.

- Adellijke titel van de echtgeno(o)t(e) en van de moeder van de zoon of dochter. Deze bestaat wederom uit vier categorieën, variërend van geen tot graaf. Weer zijn titels superieur aan graaf gecodeerd in dezelfde categorie als graaf. Buitenlandse adellijke titels zijn geclassificeerd volgens een van deze vier categorieën. Deze variabelen kunnen ook worden toegepast op patricische kinderen.

- Hoogste adellijke titel van de beide schoonouders van de zoon of dochter. Deze variabele bestaat ook uit vier categorieën, lopend van geen tot graaf. Opnieuw zou dit ken- 
merk kunnen worden toegepast op patricische zonen en dochters.

- Elitepositie van zonen of dochters, van zijn of haar echtgeno(o)t(e) en van beide ouders. Om te kunnen vaststellen of een individu een elitepositie bekleedt, worden zijn of haar beroepskring, publieke functies en dergelijke erbij betrokken. In dit onderzoek hanteren we zowel een 'smalle' als een 'brede' omschrijving van het begrip elitepositie. De smalle omschrijving is al eerder gebruikt door Dronkers en Hillege (1997, 1998), Dronkers (2000) en Dronkers en Schijf (2002). Daaronder vallen onder anderen ministers, leden van het parlement, Raad van State, de secretarissen-generaal van ministeries, de Commissarissen van de Koningin, de burgemeesters van provinciale hoofdsteden en Amsterdam en Rotterdam, de belangrijkste ambassadeurs, de leden van de Hofhouding, directeuren en commissarissen van grote ondernemingen. Tezamen vormen deze posities een mix van politieke, bestuurlijke en economische eliteposities. De brede omschrijving van eliteposities omvat verder nog: hoge ambtenaren, leden van de Provinciale Staten, wethouders, burgemeesters, ambassadeurs op minder belangrijke posten, militairen met op zijn minst de rang van generaal, hoogleraren en directeuren van kleinere bedrijven. De brede omschrijving van eliteposities beslaat dus de strata direct onder die gedefinieerd door de smalle omschrijving. Beroepen en functies waar de sociale betekenis niet ondubbelzinnig van kon worden vastgesteld, zijn uit de brede omschrijving weggelaten om te voorkomen dat de analyse vertekend raakt. Hieronder vallen bijvoorbeeld ongespecificeerde hoofden van afdelingen en universiteiten; managers van nauwelijks bekende of kleine firma's; ongespecificeerde ondernemers, handelaren en bankiers; adviseurs. Onze lijst van eliteposities is dus een conservatieve schatting van de eliteposities bekleed door de zonen en dochters.

- Eliteposities binnen de huishoudens van zoon of dochter en die van zijn of haar ouders. We hebben deze twee variabelen geconstrueerd door een combinatie van de elitepositie van een zoon of dochter en zijn of haar partner, respectievelijk door het combineren van de elitepositie van zijn of haar vader en moeder.

\section{Hypotheses}

Het blijvend belang van sociaal en cultureel kapitaal weerspreekt de aannames voortvloeiend uit de moderniseringstheorie niet. Maar het verkrijgen van sociaal en cultureel kapitaal met de hulp van overgeërfde of aan de adel gerelateerde kenmerken is in tegenspraak met deze aannames, die meritocratische criteria benadrukken. We zullen de volgende vier hypotheses toetsen:

- Gedurende de twintigste eeuw bekleden Nederlandse adellijke families meer eliteposities dan patricische families. Deze hypothese is gebaseerd op de uitkomsten van eerder onderzoek dat laat zien dat de adel een significant en gedurende de twintigste eeuw stabiel voordeel heeft bij het verwerven van eliteposities. We nemen aan dat de manier waarop de delen van het Nederland's Patriciaat zijn samengesteld het patriciaat een grotere kans oplevert ten aanzien van eliteposi- 
ties, maar niet genoeg om de leden van het patriciaat een voorsprong te geven.

- Het verschil in eliteposities tussen adel en patriciaat is niet significant afgenomen voor die generaties met een min of meer afgeronde levensloop.

- De kans op het bereiken van een elitepositie is gedurende de twintigste eeuw niet afgenomen voor verschillende generaties van de Nederlandse adel of het Nederlands patriciaat.

- Adellijke families zijn beter in staat om eliteposities naar de volgende generatie over te dragen dan patricische families.

De eerste hypothese is gebaseerd op twee conclusies uit eerder onderzoek. In de eerste plaats het permanente burgerlijke element als voordeel van de Nederlandse adel en in de tweede plaats de hogere selectiviteit van opname in het Nederland's Patriciaat. Ons baserend op een combinatie van beide observaties nemen we aan dat de Nederlandse adellijke families meer eliteposities bekleden dan de patricische families in de twintigste eeuw. De andere hypotheses zijn gebaseerd op een andere conclusie uit eerder onderzoek: het voortdurend voordeel van de Nederlandse adel in het bereiken van eliteposities gedurende de twintigste eeuw. We nemen daarom aan dat hun sociale afstand ten opzichte van de patricische families, maar ook ten opzichte van de Nederlandse samenleving als geheel, niet dramatisch is afgenomen gedurende de twintigste eeuw.

De volgende paragraaf begint met een beschrijving van de algemene kenmerken van de Nederlandse adellijke en patricische kinderen geboren tussen 1899 en 1951 en de overeenkomstige kenmerken van de ouders, de echtgeno(o)t(e) en de schoonouders. In paragraaf 6 wordt de intergenerationele overdracht van eliteposities binnen gezinnen geanalyseerd.

\section{Kinderen en ouders, adellijke en patricische families}

In de tabellen $1 \mathrm{a}$ en $1 \mathrm{~b}$ staan de kenmerken van de adellijke en patricische kinderen, hun echtgeno(o)t(e), hun ouders en hun schoonouders.

\section{De adel}

De kolommen met een letter ' $A$ ' in tabellen $1 \mathrm{a}$ en $1 \mathrm{~b}$ laten, onder andere, de aanwezigheid van adellijke titels onder zonen of dochters, ouders, echtgeno(o)t(e) en schoonouders zien. Om de presentatie van de gegevens te vereenvoudigen, hebben we alle soorten adellijke titels in één categorie geplaatst. Zonen en dochters en hun vaders bezitten per definitie een adellijke titel, maar moeders zijn niet altijd in het bezit van zo'n titel. De moeder van de zoon of dochter heeft vaker een adellijke titel $(25,7 \%$ voor zonen en $\mathbf{2 7 , 1} \%$ voor dochters) dan de echtgeno(o)t(e) van de zoon of dochter (12,9\% voor zonen en 18,2\% voor dochters). Echter, één van de schoonouders van de kinderen heeft vaker een adellijke titel (15,7\% voor zonen en $\mathbf{2 1 , 2} \%$ voor dochters) dan de echtgeno(o)t(e). De gegevens laten zien dat onder de generatie van 


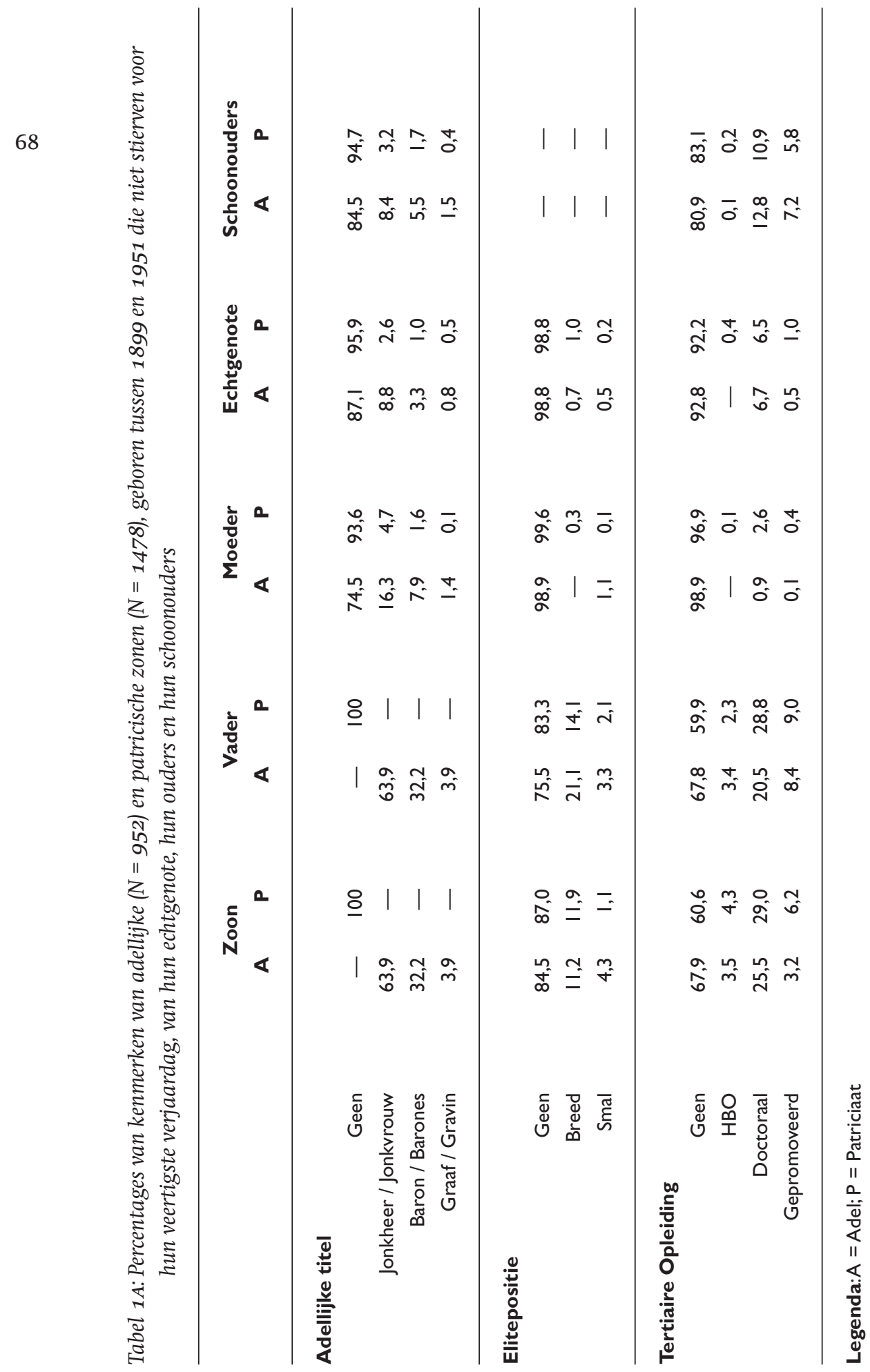




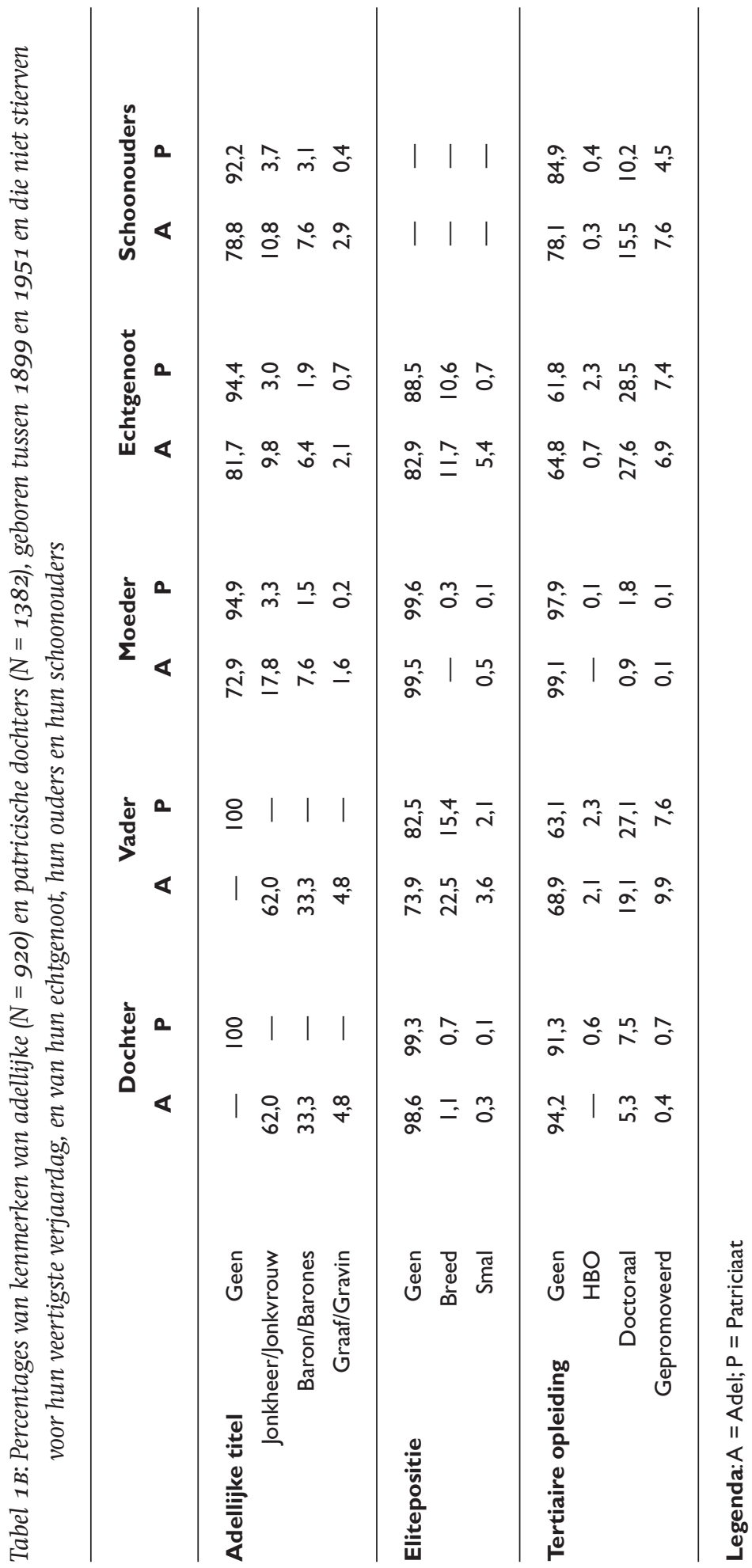


ouders de adellijke homogamie nog steeds tamelijk hoog was gedurende de twintigste eeuw, maar dat er een afname is in de adellijke homogamie bij de zonen en dochters. Maar we zien nog steeds een grotere geneigdheid onder adellijke vrouwen om met een aristocraat te trouwen dan onder hun mannelijke tegenhangers. Dit komt overeen met een algemene neiging van vrouwen om omhoog te willen trouwen, zelfs in de moderne samenleving.

Uit tabel 1a wordt ook duidelijk dat zonen minder eliteposities hebben behaald dan hun vaders $(17,3 \%$ versus $24,5 \%$; brede en smalle eliteposities tezamen), maar dat hun echtgenotes meer eliteposities verwierven dan hun moeders $(5,1 \%$ versus 1,1\%). Deze afname bij mannelijke adel in bereikte eliteposities heeft betrekking op de brede eliteposities maar niet op de smalle posities, zoals te zien is in de tabel. We kunnen ook zien dat zonen en hun echtgenotes meer smalle eliteposities bekleden dan hun ouders $(4,8 \%$ en $2,0 \%$, respectievelijk $3,3 \%$ en $1,1 \%)$. Deze concentratie in afname in de brede eliteposities zou kunnen komen door het verlies van plaatselijk gevestigde eliteposities (bijvoorbeeld burgemeesters van kleine gemeentes). De dochters (tabel $1 \mathrm{~b}$ ) bereiken minder eliteposities dan hun vaders (1,5\% versus $26,1 \%)$. Hun echtgenoten bekleden ook minder eliteposities (19,9\% versus 26,1\%). Maar als we alleen de smalle eliteposities in beschouwing nemen dan is het resultaat nogal verschillend: de echtgenoten van de dochters bereiken vaker een smalle elitepositie dan de vaders van de dochters $(6,2 \%$ versus $3,6 \%)$. Dit zou wederom de neiging van vrouwen om omhoog te trouwen kunnen weergeven, of de wens van ambitieuze mannen te trouwen met een vrouw van adel om zo eigen sociaal kapitaal te verstevigen en aldus eliteposities te bereiken. Het feit dat dochters vaker eliteposities verkrijgen dan hun moeders $(1,5 \%$ versus $0,5 \%)$ kan als indicatie gezien worden van een meer algemene emancipatie van vrouwen in de moderne samenleving.

Zonen (tabel 1a) zijn niet vaker in het bezit van een tertiair onderwijsdiploma dan hun vaders (32,2\% versus $32,3 \%)$. Maar dochters (tabel $1 \mathrm{~b}$ ) hebben vaker een tertiair diploma dan hun moeder (5,7\% versus $1,0 \%$ ). Het onderwijsniveau van de echtgenotes is min of meer vergelijkbaar met dat van de dochters $(7,2 \%$ versus $5,7 \%$ met een tertiair diploma). Hetzelfde geldt voor het onderwijsniveau van de echtgenoten en de zonen (35,2\% versus $32,2 \%)$. We kunnen concluderen dat meer jonge vrouwen in de steekproef hoger opgeleid zijn dan hun moeder, wat overeenkomt met het algemene patroon in de moderne samenleving.

\section{Het patriciaat}

De kolommen met een letter 'P' in tabellen 1a en $1 \mathrm{~b}$ laten, onder andere, zien dat de moeders, echtgeno(o)t(e) en schoonouders van patricische zonen en dochters soms van adellijke afkomst zijn. Patricische zonen en vaders hebben per definitie geen adellijke titel in het bezit. Er zijn niet altijd meer adellijke moeders aanwezig $(6,4 \%$ voor zonen en 5,0\% voor dochters) dan een adellijke echtgeno(o)t(e) van de kinderen $(4,1 \%$ voor zonen, maar $5,6 \%$ voor dochters $)$ in deze patricische families. Deze percentages duiden erop dat patricische dochters een iets grotere voorkeur hebben om 
met een adellijke partner te trouwen dan patricische zonen. Deze bevindingen spreken zeker de algemene geneigdheid onder vrouwen om omhoog te trouwen niet tegen.

Uit tabel 1a wordt duidelijk dat zonen minder eliteposities hebben bereikt dan hun vaders, zowel breed (11,9\% versus $14,1 \%)$ als smal (1,1\% versus 2,1$)$. Maar hun echtgenotes bekleden meer brede of smalle eliteposities dan hun schoonmoeders $(1,2 \%$ versus $0,4 \%)$. De patricische dochters (tabel $1 \mathrm{~b}$ ) verwerven beduidend minder eliteposities dan hun vaders (o,8\% versus $17,5 \%)$, maar een ietwat hoger percentage dan hun moeders ( $0,8 \%$ versus $0,4 \%$ ). Hun echtgenoten bekleden ook minder eliteposities dan hun schoonvaders (11,3\% versus $17,5 \%)$.

Patricische zonen (tabel 1a) zijn niet vaker in het bezit van een tertiair diploma dan hun vaders (39,5\% versus $40,1 \%)$. Maar er is een fors verschil tussen dochters en moeders $(8,8 \%$ versus $2,0 \%)$. Het onderwijsniveau van de echtgenotes is iets lager dan dat van de dochters $(7,9 \%$ versus $8,8 \%)$. Hetzelfde geldt voor het onderwijsniveau van de echtgenoten en van de zonen ( $38,2 \%$ versus $39,5 \%)$. Opnieuw kunnen we concluderen dat meer dochters hoger opgeleid zijn dan hun moeders, wat in overeenstemming is met het algemene patroon in de samenleving.

\section{Adel versus patriciaat}

Het eerste opvallende verschil tussen adellijke en patricische families zijn de percentages in eliteposities. Over het algemeen bekleden adellijke zonen, hun vaders en de echtgenoten van adellijke dochters meer eliteposities dan hun patricische tegenhangers. Maar de verschillen in deze percentages zijn niet geheel uniform. Terwijl er nauwelijks verschil is tussen adellijke en patricische zonen voorzover het brede posities betreft, bestaat er een aanzienlijk verschil voorzover het gaat om smalle eliteposities $(4,3 \%$ versus $1,1 \%)$. Voor vaders is er een nogal groot verschil wat betreft brede eliteposities ( $21,1 \%$ versus $14,1 \%)$ en voor de echtgenoten van adellijke dochters is het percentage van smalle eliteposities ook hoger dan voor de echtgenoten van patricische dochters $(5,4 \%$ versus $0,7 \%)$. Het tweede verschil is het tertiaire onderwijsniveau van adel en patriciaat, zowel voor de zonen (32,2\% versus $39,5 \%)$, als voor de dochters (5,7\% versus 8,8\%). Eenzelfde verschil kan niet teruggevonden worden bij de vaders, hoewel patricische ouders in het algemeen een iets hoger onderwijsniveau hebben dan de adellijke. Er is tevens een verschil tussen het onderwijsniveau van adellijke en patricische echtgenoten (35,2\% versus $38,2 \%)$.

Het is duidelijk dat de adel niet minder eliteposities heeft verworven dan het patriciaat en dat de adel zelfs meer smalle eliteposities bekleedt dan het patriciaat. Tabellen $1 \mathrm{a}$ en $\mathrm{1b}$ bevestigen daarom de eerste hypothese dat de adel meer eliteposities heeft dan het patriciaat. Een combinatie van deze bevindingen en het lagere onderwijsniveau onder de adel suggereert dat het bezitten van een adellijke titel een aankomende factor zou kunnen zijn om het relatief hoge percentage eliteposities dat de adel bekleedt te verklaren. 


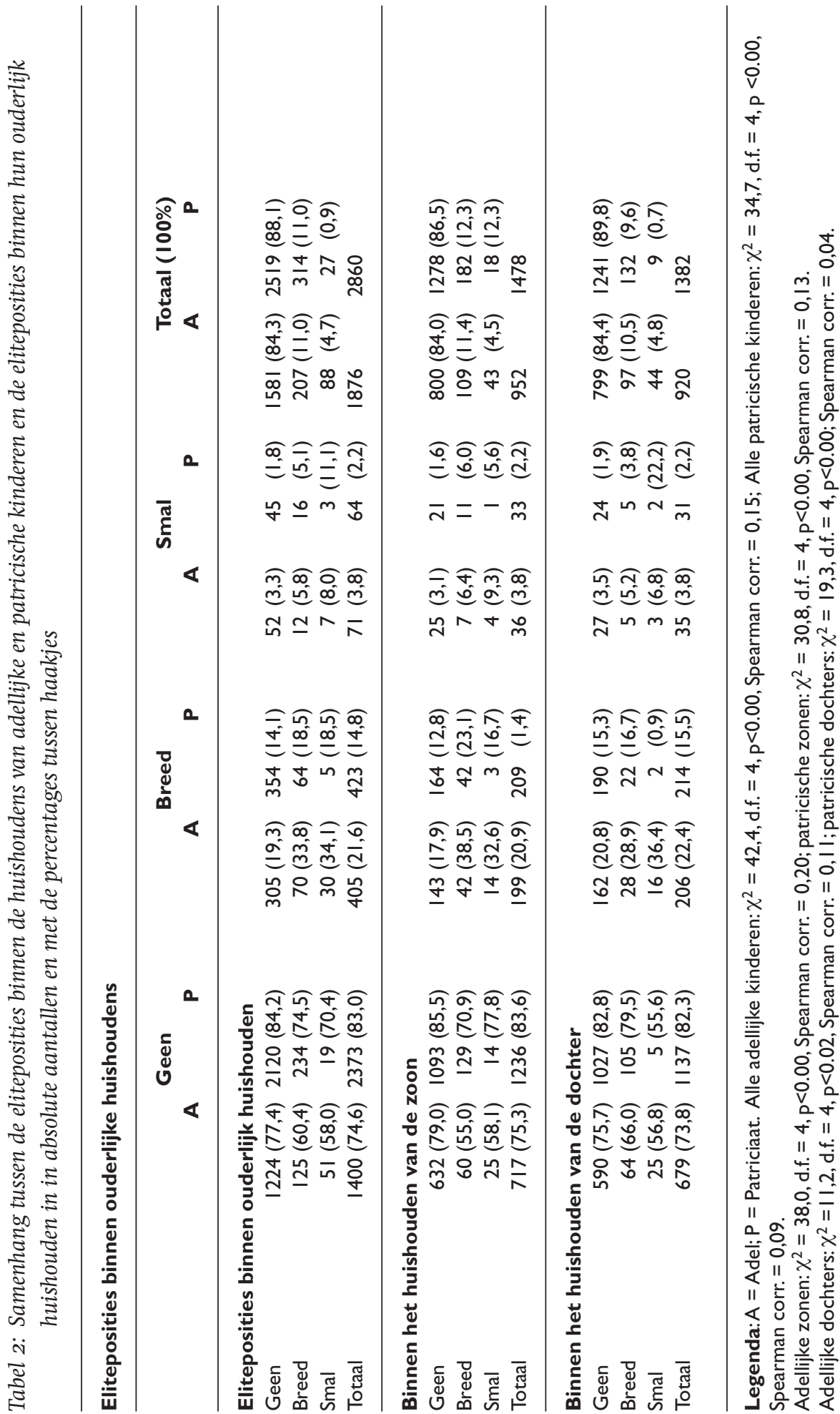




\section{Intergenerationele overdracht van eliteposities}

Tabel 2 toont dat kinderen van ouders die een smalle of brede elitepositie bekleden iets waarschijnlijker zelf een elitepositie verwerven of in een elitehuishouden wonen. De relatie tussen eliteposities van adellijke huishoudens van de ouders en de huishoudens van de kinderen is statistisch significant (de correlatie is 0,15). Maar deze relatie is sterker voor zonen dan voor dochters (de correlaties zijn respectievelijk 0,20 en $\mathbf{0 , 1 1}$ ). Voor patricische families zien we dezelfde significante relatie, maar de correlatie is lager $(0,09)$ en weer is de correlatie hoger voor zonen dan voor dochters (respectievelijk 0,13 en 0,04). Maar beide correlaties zijn lager dan die voor de adellijke kinderen, vooral die voor de dochters.

De volgende vraag is of de intergenerationele overdracht van eliteposities binnen de adel is afgezwakt gedurende de twintigste eeuw. Wanneer de zoon of dochter voor 1940 geboren is, veranderde deze overdracht nauwelijks, zoals te zien is in tabel 3. De correlaties voor zowel adellijke als patricische generaties is ongeveer 0,15 . De correlatie voor het jongste cohort is iets lager $(0,13)$, maar dit zou verklaard kunnen worden door de relatief jonge leeftijd van dit cohort, tussen de veertig en vijftig jaar, in de periode dat de informatie over beroepen en posities verzameld werd. Deze jonge leeftijd heeft gezorgd voor rechts gecensureerde beroepscarrières, dat wil zeggen dat dit cohort nog te jong is om de top van hun carrière bereikt te hebben. Voor de patricische huishoudens zien we een soortgelijk patroon, maar voornamelijk de correlatie voor de oudste generatie is veel kleiner dan die van de adellijke tegenhanger. In de middengeneratie neemt de correlatie enigszins toe, maar deze is nog altijd lager dan die voor de adellijke huishoudens, en hij blijft constant voor de jongste generatie. Dit zou kunnen aangeven dat patricische families, tot op zekere hoogte, inlopen op adellijke families, wat verklaard zou kunnen worden door het toenemende hoge niveau van onderwijs onder de jonge leden van patricische families.

\section{Brede en smalle eliteposities verklaard}

Om onze hypotheses te toetsen dienen we te controleren op verschillen in sociale achtergrond (opleiding, echtgeno(o)t(e), ouderlijke achtergrond, schoonouders) onder adellijke en patricische kinderen. We zullen twee logistische regressieanalyses presenteren. Tabel 4 laat de kans zien om een elitepositie (zowel breed als smal) te verwerven als afhankelijke variabele, terwijl tabel 5 zich beperkt tot de kans om een smalle elitepositie te bereiken. Beide geconstrueerde variabelen 'elitepositie binnen de huishoudens van zonen of dochters' en 'ouderlijke elitepositie' (zie paragraaf 4) zijn bij de analyse betrokken. Dit maakt het mogelijk zowel zonen als dochters op te nemen in dezelfde analyses, want al bereiken dochters veel minder vaak een elitepositie dan zonen, zij zijn vaker dan zonen getrouwd met een partner met een elitepositie, zoals tabellen 1a en 1b hebben laten zien. Dus de variabele 'elitepositie binnen het gezin' meet of zonen of dochters deze positie hebben verworven door eigen posities of door getrouwd te zijn met iemand met een elitepositie. Het 


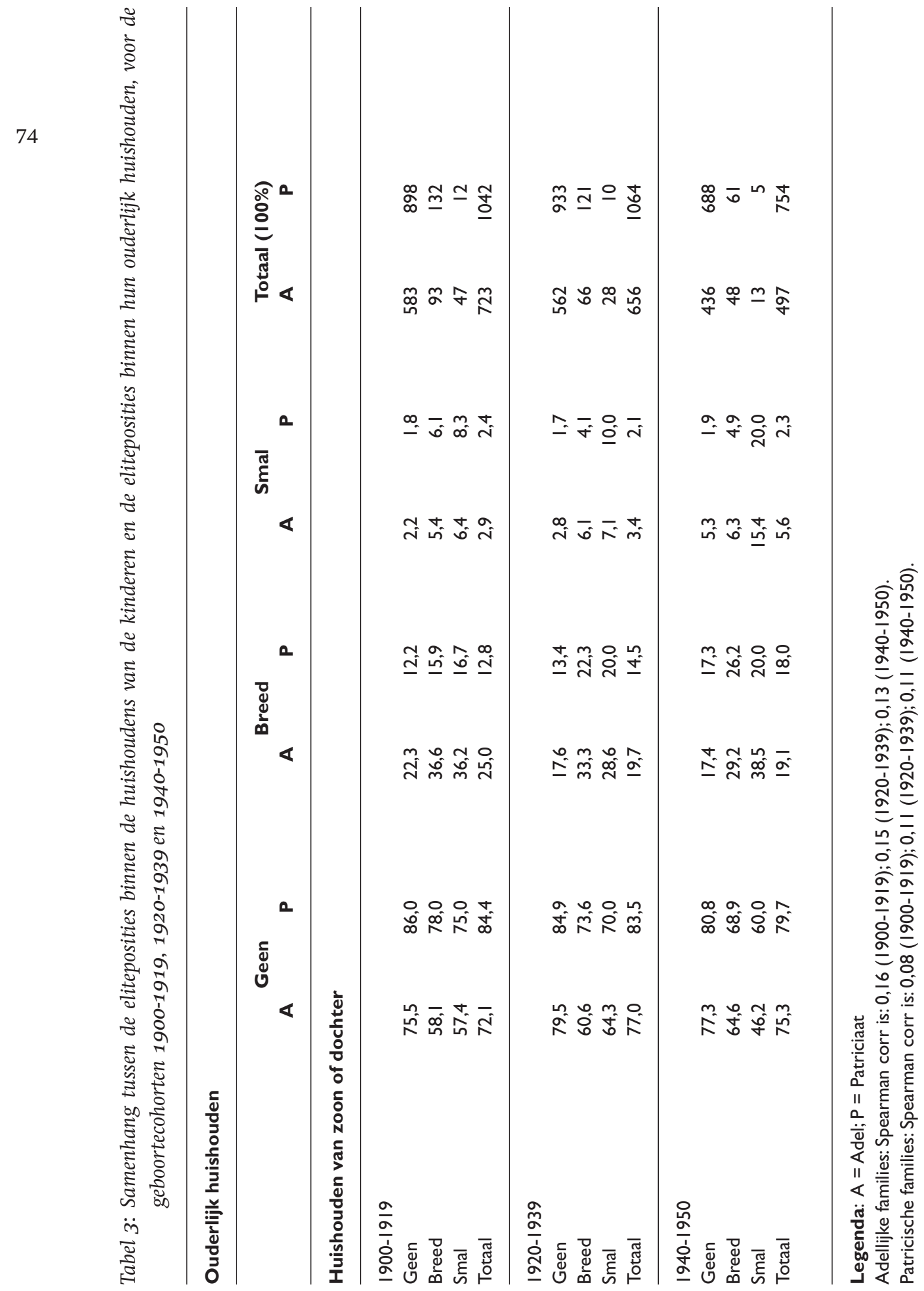


belang van het gezinsmilieu om eliteposities te verkrijgen en de intergenerationele overdracht van deze posities kan zo met enige precisie bestudeerd worden. De geconstrueerde variabele betreffende het ouderlijk huishouden is natuurlijk gedomineerd door de elitepositie van de vader, maar houdt ook met die paar eliteposities bekleed door moeders rekening (tabel 1a en 1b). Omdat we ook kenmerken van de partners van de kinderen meerekenen, zullen deze regressieanalyses altijd beperkt blijven tot de getrouwde kinderen.

Om deze analyses van de 'elitepositie binnen het gezin' te verhelderen en te bevestigen, hebben we ook regressieanalyses berekend voor getrouwde zonen met hun individuele elitepositie als afhankelijke variabele. De stappen in dit model zijn te zien in tabel 6. (Vergelijkbare analyses voor dochters zijn statistisch onbetrouwbaar, als gevolg van het geringe aantal eliteposities bekleed door dochters.) We hebben ook een vergelijkbare analyse uitgevoerd voor alle getrouwde en ongetrouwde zonen met hun individuele elitepositie als afhankelijke variabele en dus zonder de kenmerken van huwelijkspartners of schoonouders. Deze resultaten worden niet getoond, omdat ze vergelijkbaar zijn met die van de getrouwde zonen uit tabel 6 . Deze gegevens kunnen verkregen worden bij de tweede auteur. Een vergelijking van tabellen 4, 5 en 6 illustreert de verschillen tussen het gezinsperspectief en een individueel perspectief.

De verschillende stappen in de modellen van tabellen 4 en 5 maken duidelijk welke variabelen bijdragen aan de verklaring van eliteposities binnen het huishouden van de kinderen, wanneer rekening wordt gehouden met de eigen kenmerken en die van hun ouders, partners en schoonouders. De eerste stap zet de eliteposities uiteen volgens adellijke titel en geboortecohort van de kinderen. Het eerste decennium (1900-1909) is de referentiecategorie en de achtereenvolgende parameters geven aan of de zonen of dochters die in een bepaald decennium geboren zijn een grotere kans (parameter hoger dan 1,00) of een kleinere kans (parameter lager dan 1,00) op een elitepositie hebben dan kinderen geboren in het eerste decennium. Ten tweede worden de kenmerken van de kinderen (geslacht of universitaire graad) en van de ouders (elitepositie van de ouders, universitaire graad van de vader en de moeder, en de adellijke titel van de moeder) toegevoegd. De ouderlijke elitepositie is ook opgenomen in deze stap, ongeacht de significantie van de parameter, omdat onze belangstelling uitgaat naar intergenerationele overdracht van eliteposities. Ten slotte worden de kenmerken van de huwelijkspartners van de kinderen (adellijke titel van de partner, universitaire titel) en van de schoonouders (universitaire graad van de schoonouders en de hoogste adellijke titel van de schoonouders) toegevoegd. Omdat alle andere kenmerken van kinderen en ouders enkel controlevariabelen zijn voor onze drie hypotheses, worden alleen de kenmerken met significante parameters getoond. Een interactievariabele (adel*'geboortecohort), die aangeeft of het effect van een adellijke titel anders is voor adel en patriciërs geboren in verschillende geboortecohorten, is ook bijgevoegd. Als de parameter significant hoger is dan 1,00, betekent dit dat het effect van het hebben van een adellijke titel op de kans om een elitepositie te verkrijgen, groter is in het jongere geboortecohort dan 
Tabel 4: Kans op brede of smalle elitepositie binnen het huishouden van getrouwde kinderen $(\mathrm{N}=4017)$ geboren voor 1951 (effectparameters van logistische regressieanalyse)

\begin{tabular}{|c|c|c|c|c|}
\hline & $\mathbf{I}$ & 2 & 3 & 4 \\
\hline Adel & $1,32 * *$ & $\mathrm{I}, 25^{*}$ & $\mathrm{I}, 14$ & $3,40 * *$ \\
\hline Geboortecohort 1900-1909 (ref.) & 1,00 & 1,00 & 1,00 & 1,00 \\
\hline $1910-1919$ & 1,19 & 1,05 & 1,16 & 1,06 \\
\hline $1920-1929$ & ,99 & ,93 & ,94 & ,79 \\
\hline $1930-1939$ &, $75^{*}$ &, 66 ** &, $69 *$ &, 55 \\
\hline $1940-1950$ &, $66 * *$ &, $51 * *$ &, $49 * *$ &, $36^{*}$ \\
\hline Ouderlijke elitepositie & & $1,4 I^{* *}$ & $1,28^{*}$ & $1,15^{*}$ \\
\hline Man & &, $57^{* *}$ & 1,09 &, $24^{*}$ \\
\hline Universitaire titel zoon of dochter & & $5,21 * *$ & $4,00 * *$ & $2,67^{*}$ \\
\hline Vader universitaire titel & & $1,35 * *$ & 1,14 & $\mathrm{I}, \mathrm{II}$ \\
\hline Moeder geen adellijke titel (ref.) & & 1,00 & 1,00 & 1,00 \\
\hline Moeder jonkvrouw & & $1,78 * *$ & $1,40 *$ & $1,39 *$ \\
\hline Moeder barones of hoger & & $2,71 * *$ & $2,31 * *$ & $2,29 * *$ \\
\hline Partner met universitaire titel & & & $3,66 * *$ & $3,73^{* *}$ \\
\hline Schoonouders geen adellijke titel (ref.) & & & 1,00 & 1,00 \\
\hline Schoonouders jonkheer & & & $2,12 * *$ & $2,10^{* *}$ \\
\hline Schoonouder baron of hoger & & & $2,10 * *$ & $2,09 * *$ \\
\hline Schoonouders universitaire titel & & & $1,80 * *$ & $1,76 * *$ \\
\hline Adel*geboortecohort & & & & 1,06 \\
\hline Adel*universitaire titel zoon of dochter & & &, $58 * *$ & \\
\hline Adel*ouderlijke elitepositie & & & & $\mathrm{I}, 07$ \\
\hline Man*universitaire titel & & & & $1,96 * *$ \\
\hline Nagelkerke $\mathrm{R}^{2}$ & ,01 & ,09 &, 14 &, 14 \\
\hline-2 Log likelihood & 3384 & 3040 & 2830 & 2816 \\
\hline
\end{tabular}

${ }^{*} \mathrm{p}<0,01 ;{ }^{*} \mathrm{p}<0,05$

in het oudere. Als de parameter significant lager is dan 1,00, betekent dit dat het effect van het zijn van een patricische zoon of dochter op de kans om een elitepositie te verkrijgen, is toegenomen in de jongere geboortecohorten. Gegeven onze tweede hypothese, voegen we deze interactievariabele toe aan het model, ongeacht de statistische significantie van de parameter. Uitgaande van onze vierde hypothese hebben we ook, los van zijn statistische significantie, het interactie-effect adel*elitepositie ouders toegevoegd dat aangeeft of het effect van ouders met een elitepositie sterker is bij de adel dan bij patricische families. Als de parameter significant groter is dan 1,00 betekent dit dat het effect bij adellijke families groter is dan bij patricische families. 
Tabel 5: Kans op smalle elitepositie binnen het huishouden van getrouwde kinderen ( $N=4017)$ geboren voor 1951 (effectparameters van logistische regressieanalyse)

\begin{tabular}{|c|c|c|c|c|}
\hline & I & 2 & 3 & 4 \\
\hline Adel & $4,98 * *$ & 4,38 ** & $3,97 * *$ & $5,65^{* *}$ \\
\hline Geboortecohort 1900-1909 (ref.) & 1,00 & 1,00 & $\mathrm{I}, 00$ & $\mathrm{I}, 00$ \\
\hline $1910-1919$ & 1,06 & 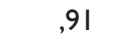 & $\mathrm{I}, 05$ & $\mathrm{I}, 34$ \\
\hline $1920-1929$ & ,79 & ,73 & ,80 & $\mathrm{I}, 30$ \\
\hline $1930-1939$ &, 58 &, $52^{*}$ & ,60 & 1,22 \\
\hline $1940-1950$ &, $44^{* *}$ & ,38** &, $40 * *$ & $\mathrm{I}, 04$ \\
\hline Ouderlijke elitepositie & & $1,63^{*}$ & $\mathrm{I}, 3 \mathrm{I}$ & ,98 \\
\hline Man & &, $60^{*}$ & 1,06 & 1,06 \\
\hline Universitaire titel zoon of dochter & & $3,77^{* *}$ & $2,95 * *$ & $2,94^{* *}$ \\
\hline Moeder geen adellijke titel(ref.) & & 1,00 & $\mathrm{I}, 00$ & $\mathrm{I}, 00$ \\
\hline Moeder jonkvrouw & & $2,11 * *$ & $\mathrm{I}, 63^{*}$ & $1,62^{*}$ \\
\hline Moeder barones of hoger & & $1,84^{*}$ & $\mathrm{I}, 47$ & $\mathrm{I}, 4 \mathrm{I}$ \\
\hline Partner met universitaire titel & & & $2,78 * *$ & $2,75^{* *}$ \\
\hline Schoonouders geen adellijke titel (ref.) & & & 1,00 & $\mathrm{I}, 00$ \\
\hline Schoonouders jonkheer & & & $3,27 * *$ & $3,20 * *$ \\
\hline Schoonouders baron of hoger & & & 1,66 & 1,64 \\
\hline Schoonouders universitaire titel & & & $\mathrm{I}, 68^{*}$ & $1,69 *$ \\
\hline Adel*geboortecohort & & & & ,87 \\
\hline Adel*ouderlijke elitepositie & & & & $\mathrm{I}, \mathrm{I5}$ \\
\hline Nagelkerke $\mathrm{R}^{2}$ & 08 &, 14 &, 19 &, 20 \\
\hline -2 Log likelihood & 936 & 881 & 832 & 831 \\
\hline
\end{tabular}

$*^{*} \mathrm{p}<0,01 ; *^{p}<0,05$

We hebben ook enkele andere interactievariabelen toegevoegd aan de vierde stap: adel*academische titel van zoon of dochter; geboortecohort*academische titel van zoon of dochter; adel*geslacht; geboortecohort*geslacht; academische titel van zoon of dochter*geslacht; geslacht*ouderlijke elite; geboortecohort*ouderlijke elite; geboortecohort*adellijke titel moeder; geboortecohort*adellijke titel schoonouders; geboortecohort*academische titel partner. Alleen de kenmerken met significante parameters worden getoond. Controlevariabelen, die na het toevoegen van andere controlevariabelen in een volgend model niet significant worden, zijn niet weggehaald. Tabel 6 toont alleen de resultaten van het vierde en laatste model voor getrouwde zonen, maar wederom kunnen de resultaten van de andere modellen verkregen worden bij de tweede auteur.

De parameter van de 'adel'-variabele in tabel 4 is altijd significant hoger dan 
1,00, hetgeen aangeeft dat adellijke zonen en dochters een grotere kans hebben een brede of smalle elitepositie binnen een huishouden te verwerven dan patricische kinderen met dezelfde kenmerken. Dit adellijke voordeel kan gedeeltelijk verklaard worden door de kenmerken van de huwelijkspartners en schoonouders (stap 3): vooral de universitaire titels of adellijke titels van de schoonouders zijn significante voorspellers van een elitepositie. Schoonouders van adellijke kinderen hebben vaker een adellijke titel of een universitaire titel dan schoonouders van patricische kinderen (tabel 1a en 1b). Stap 4 in tabel 4 laat zien dat het voordeel van adellijke kinderen bijna viermaal zo groot is, als we in aanmerking nemen dat een universitaire graad minder belangrijk is voor adellijke kinderen om een elitepositie te bereiken dan voor een patricische zoon of dochter (interactievariabele adel*academische titel van zoon of dochter).

Dit voordeel van de adel wordt zelfs nog duidelijker als de smalle eliteposities binnen een huishouden apart worden genomen: adellijke kinderen hebben een bijna zes keer zo grote kans om een smalle elitepositie binnen een huishouden te verwerven dan patricische kinderen met dezelfde kenmerken (tabel 5). Ditzelfde voordeel was al evident in tabel 1a en $1 \mathrm{~b}$, maar deze analyse (tabel 5) laat zien dat deze oorspronkelijke uitkomst niet verklaard kan worden door verschillen in de andere kenmerken van de adellijke en patricische kinderen. Hoewel dit voordeel kleiner lijkt te worden in de jongere geboortecohorten, is deze afname niet significant (interactievariabele adel*geboortecohort in model 4).

Het voordeel in het verwerven van eliteposities voor adellijke zonen en dochters blijft waar als we ons alleen richten op de zonen en hun individuele eliteposities (tabel 6). Dit voordeel voor adellijke zonen is meer dan zeven keer zo groot voor brede of smalle eliteposities en meer dan vijf keer zo groot voor smalle eliteposities in vergelijking met een patricische zoon met dezelfde kenmerken. Weer zien we dat een universitaire titel minder belangrijk is voor adellijke kinderen om een brede of smalle elitepositie te verkrijgen dan voor een patricische zoon of dochter (interactievariabele adel*academische titel van zoon of dochter). Opvallend is dat de adellijke titel van de moeder van de kinderen belangrijker wordt voor de jongere geboortecohorten om een smalle elitepositie te verwerven. Al deze resultaten bevestigen onze eerste hypothese. De strengere selectie voor opname in het Nederland's Patriciaat, die een significant voordeel voor de patricische kinderen zou hebben moeten opleveren, wordt meer dan volledig gecompenseerd door het belang van het hebben van een Nederlandse adellijke titel en dit voordeel neemt niet significant af voor de verschillende generaties, hetgeen onze tweede hypothese bevestigt. Er is zelfs een kleine aanwijzing dat het belang van de adellijke titel van de moeder is toegenomen voor de jongere generaties.

Tabellen 4 en 5 laten zien dat adellijke en patricische kinderen geboren tussen 1940 en 1950 een significant lagere kans hebben om een elitepositie te bekleden in de jaren negentig dan de eerder geboren kinderen. Zoals we eerder hebben vermeld, zou deze kleinere kans verklaard kunnen worden door de relatief jonge leeftijd van deze generatie in de jaren negentig, hetgeen leidt tot rechts gecensureerde data 
omdat hun carrières nog niet de top hebben bereikt. Maar het is ook waar dat de zonen en dochters geboren tussen 1930 en 1940 een kleinere kans hebben een elitepositie te verwerven, hoewel in de meeste gevallen de parameters niet significant zijn. Als we deze parameters voor een brede of smalle elitepositie (tabel 4) met die voor enkel een smalle elitepositie (tabel 5) vergelijken, zijn de geringere kansen van de kinderen geboren tussen 1930 en 1940 alleen significant voor brede of smalle eliteposities en niet voor enkel smalle eliteposities. We kunnen concluderen dat de waarschijnlijkheid van het bereiken van welke elitepositie dan ook door zowel adellijke als patricische kinderen is verminderd (in tegenstelling tot onze derde hypothese), maar dat de waarschijnlijkheid van het bereiken van een smalle elitepositie voor zowel adellijke als patricische kinderen niet is verminderd (onze derde hypothese bevestigend). Dit verschil tussen smalle en brede eliteposities kan worden verklaard door het verlies van lokale eliteposities (bijvoorbeeld burgemeesters van kleine gemeentes) van zowel de adel als het patriciaat ten gevolge van de professionalisering van lokaal bestuur en het verdwijnen van kleine gemeentes.

De intergenerationele overdracht van eliteposities van adellijke en patricische ouders naar hun kinderen, zoals beschreven in tabel 3, kan niet geheel verklaard worden door andere kenmerken van ouders en kinderen (onderwijs, huwelijk). Tabel 4 geeft in model 2 en 3 significante en positieve parameters weer van de variabele elitepositie van de ouders voor de waarschijnlijkheid van een brede of smalle elitepositie binnen een huishouden. Het effect wordt insignificant in model 4 als gevolg van het introduceren van interactievariabelen. De intergenerationele overdracht van de brede of de smalle eliteposities wordt voor zonen bevestigd in tabel 6 . Het niet-significante interactie-effect adel*ouderlijke eliteposities wijst erop dat deze intergenerationele overdracht bij de adel niet sterker is dan bij de patricische families. Dat is in strijd met de vierde hypothese.

Deze intergenerationele overdracht bestaat echter niet als we ons alleen richten op enkel de smalle eliteposities. De parameter van de ouderlijke eliteposities wordt niet-significant in tabel 5, nadat er is gecontroleerd voor de kenmerken van partner en schoonouders. We vinden ook een niet-significante parameter in tabel 6. Het niet-significante interactie-effect adel*ouderlijke eliteposities geeft aan dat intergenerationele overdracht van eliteposities bij de adel niet sterker werkt dan bij de patricische families wat in strijd is met de vierde hypothese. Dus intergenerationele overdracht van eliteprivileges bestaat, maar het functioneert alleen om een breed gedefinieerde elite binnen te komen. Het helpt niet om de smalle eliteposities te bereiken, waarschijnlijk door de fellere competitie voor de zeer schaarse posities en het fenomeen van 'regressie naar het gemiddelde'.

Tabel 4 en 5 laten zien dat de kleinere kans om een elitepositie binnen het gezin van de zonen te verwerven (stap 2) verdwijnt als we controleren voor de kenmerken van huwelijkspartners en schoonouders (stap 3). Dit betekent dat dochters een grotere kans hebben om in een elitegezin te wonen dan zonen met hetzelfde onderwijsniveau en dezelfde ouderlijke kenmerken. Zodra we controleren voor de kenmerken van partner en schoonouders, verdwijnt deze hogere kans en hebben zonen 
Tabel 6: Kans op elitepositie voor getrouwde zoons $(\mathrm{N}=2133)$ geboren voor 1951 (effectparameters van logistische regressieanalyse)

\begin{tabular}{|c|c|c|}
\hline & Breed of smal & Smal \\
\hline Adel & $7,33 * *$ & $4,93^{*}$ \\
\hline Geboortecohort 1900-1909 (ref.) & 1,00 & 1,00 \\
\hline $1910-1919$ & 1,27 & 1,42 \\
\hline $1920-1929$ & ,94 & 1,65 \\
\hline $1930-1939$ &, 57 & 1,63 \\
\hline $1940-1950$ & ,39 & ,87 \\
\hline Ouderlijke elitepositie & $2,07^{*}$ & 65 \\
\hline Universitaire titel zoon of dochter & $18,20 * *$ & $3,76 * *$ \\
\hline Moeder geen adellijke titel (ref.) & 1,00 & - \\
\hline Moeder jonkvrouw & 1,03 & - \\
\hline Moeder barones of hoger & $2,57^{* *}$ & - \\
\hline Schoonouders geen adellijke titel (ref.) & 1,00 & 1,00 \\
\hline Schoonouders jonkheer & $2,08 * *$ & $2,91 * *$ \\
\hline Schoonouders baron of hoger & $\mathrm{I}, 87^{*}$ & $\mathrm{I}, 82$ \\
\hline Schoonouders universitaire titel & $1,74 * *$ & - \\
\hline Adel*geboortecohort & 1,04 & ,86 \\
\hline Adel*universitaire titel &, $47 * *$ & - \\
\hline Moeder adel*geboortecohort & - & $1,17^{*}$ \\
\hline Adel*ouderlijke elitepositie &, 95 & 1,25 \\
\hline Nagelkerke $\mathrm{R}^{2}$ & 15 &, 17 \\
\hline -2 Log likelihood & 1467 & 428 \\
\hline
\end{tabular}

$*_{p}<0,01 ; *_{p}<0,05$

en dochters een min of meer gelijke kans om in een elitegezin te wonen. Dus kan de hogere waarschijnlijkheid van dochters om in een elitehuishouden te wonen geheel verklaard worden door het omhoog trouwen onder dochters en het omlaag trouwen onder zonen, zoals eerder is gedocumenteerd. Het is belangrijk erbij stil te staan dat dit effect van gender niet significant verschilt per geboortecohort.

Een 'goed' huwelijk van de kinderen en van de ouders is ook van belang bij het verwerven van een elitepositie, zoals tabellen 4 en 5 laten zien. De adellijke titel en de universitaire titel van de schoonouders hebben statistisch significante parameters in bijna alle modellen. Dit kan niet verklaard worden door de kenmerken van de partner. Hetzelfde geldt voor de adellijke titel van de moeder en dit positieve effect kan ook niet verklaard worden door de adellijke titel van de zoon of dochter. Deze 'goed huwelijk'-effecten nemen niet af voor de jongere geboortecohorten. Tabel 6 toont dat dit 'goed huwelijk'-effect alleen waar is voor zonen. 


\section{Conclusie}

Onze statistische analyses bevestigen de eerste, tweede en derde hypothese, maar verwerpen de vierde. Adellijke families in Nederland bekleden gedurende de twintigste eeuw meer eliteposities dan patriciaatfamilies. De belangrijkste verklaring voor deze dominantie moet worden gezocht in het blijvende vermogen om hun aan de adel gerelateerde sociaal en cultureel kapitaal, aangegeven door de adellijke titels van de vader, de hoge adellijke titels van de moeder en van de schoonouders, te gebruiken. Dit voordeel is niet verminderd voor die generatie die een min of meer voltooide carrière achter zich heeft. Alleen bij de jongste generatie is er een significant negatief effect op de kans op het bereiken van een elitepositie. Dat is duidelijker het geval bij de brede elite dan bij de smalle elite, maar dit effect geldt zowel voor de adel als het patriciaat. De conclusie is daarom dat in vergelijking met het patriciaat de kans om een elitepositie te bereiken voor de verschillende adellijke generaties niet is verminderd. Vergeleken met de huwelijken van de ouders is in de generatie van de kinderen het aantal homogene huwelijken afgenomen. Dat zou een verklaring kunnen zijn voor geleidelijke afname in eliteposities bij zowel de adel als het patriciaat, hoewel het met de adel verbonden sociaal en cultureel kapitaal niet is afgenomen.

Alle resultaten bevestigen een eerdere conclusie (Dronkers, 2000, Dronkers \& Schijf, 2002) dat de kans om een elitepositie te bereiken voor de adel in Nederland nauwelijks is verminderd gedurende de twintigste eeuw. Nog algemener geformuleerd, de uitkomsten van dit artikel bevestigen opnieuw de conclusies van ander onderzoek (zie paragraaf 2 ) dat een adellijke titel nog steeds voordeel oplevert bij het verwerven van een elitepositie in Nederland, ook in vergelijking met het patriciaat.

Deze resultaten zijn in tegenspraak met veronderstellingen over modernisatie en sociale mobiliteit gebaseerd op meritocratische kenmerken. Niettemin is ook algemeen cultureel kapitaal, zoals onderwijs en in het bijzonder academische titels, van belang om een elitepositie te verwerven, zoals we hebben gezien. Het behalen van een hoog onderwijsniveau kan worden gezien als een strategie van de adel om zich aan de eisen van de moderne samenleving aan te passen. Deze speciale strategie is zelfs sterker bij patriciaatfamilies. Dat een academische titel de kans vergroot om een elitepositie te verwerven, sluit geheel aan bij de veronderstelling dat verworven kwaliteiten steeds belangrijker worden in een moderne samenleving. Dat zou ook belangrijker kunnen zijn voor een bestuursadel dan voor een zwaard- of landadel. Het is zeker belangrijk voor de hoge bourgeoisie.

Rekening houdend met kenmerken verbonden aan de adel, bestaat er nog steeds een statistisch significante overdracht tussen het ouderlijk gezin en dat van de kinderen als het om het verwerven van eliteposities gaat en de overdracht is bij adellijke families niet sterker dan bij families uit het patriciaat. Deze conclusie stemt niet overeen met de veronderstelde openheid van moderne westerse samenlevingen, maar zal geen verrassing zijn voor iedereen die bekend is met onderzoek naar elites (Bottomore, 1993). Wat de adel echter onderscheidt van andere elites is zijn vermogen om specifiek adellijk sociaal en cultureel kapitaal, zowel in het ouderlijk 
gezin als in het eigen huishouden, te combineren met algemeen sociaal en cultureel kapitaal. Gegeven de mogelijkheden die het opgroeien in een adellijk milieu met een elitepositie oplevert, biedt een huwelijk in dit milieu een goede strategie om een elitepositie te bereiken. Dat zou opnieuw in strijd zijn met de veronderstelde openheid van de moderne Nederlandse samenleving.

Een mogelijkheid om onze resultaten en de modernisatietheorie te combineren kan de aanname zijn dat sociale ongelijkheid in moderne samenlevingen in toenemende mate gebaseerd is op prestaties. Dit zou echter alleen gelden voor de middenklasse die de meerderheid vormt in moderne samenlevingen. De hogere klasse zoals in dit artikel beschreven, zou minder worden beïnvloed door deze modernisering. Dat komt vooral omdat bij de competitie om eliteposities sociaal en cultureel kapitaal en de juiste kennissenkring van groter belang zijn dan kenmerken die gebaseerd zijn op prestaties, zoals een universitair diploma. We kunnen dus vaststellen dat de modernisatietheorie zich richt op de samenleving als geheel, terwijl onze resultaten zich richten op de meer extreme posities. Dit verschil in aandacht zou de elkaar tegensprekende resultaten kunnen verklaren en verzoenen. De modernisatietheorie gaat alleen maar op voor de brede middenklasse, de theorie is echter veel minder toepasbaar als het gaat om extreme posities als elites of werklozen en uitvallers.

Op grond van ons onderzoek beweren we niet dat de adel nog steeds een belangrijke rol speelt in de Nederlandse samenleving. Wel menen we dat het onderzoek laat zien dat personen die tot een groep behoren die in het bezit is van een specifieke combinatie van symbolisch, sociaal en cultureel kapitaal voordelen heeft in het bereiken van eliteposities, zelfs in een moderne burgerlijke samenleving als de Nederlandse. Hoewel dit kapitaal gedeeltelijk is gebaseerd op verworven kenmerken, is de groep in staat gebleken zich te handhaven, wat ook de invloed van modernisering en de nadruk op meritocratische kwaliteiten moge zijn geweest in de twintigste eeuw. Het resultaat weerspreekt bovendien de dikwijls geopperde veronderstelling dat de adel totaal verouderd is. Saint Martin (1993) heeft dit voortdurende vermogen om zich aan nieuwe omstandigheden aan te passen bij de Franse adel laten zien en we zouden de hypothese willen poneren dat dit een algemeen patroon is in West-Europese landen waar een adel bestaat. Eliteposities staan wellicht open voor iedereen met de juiste kwalificaties, maar ze staan meer open voor sommigen dan voor anderen, en een adellijke stamboom komt nog steeds van pas.

\section{Noot}

1. Een eerdere versie van dit artikel werd als paper gepresenteerd in de Sessie Eliten, Marktdag Sociologie, Nijmegen 22 mei 2003. We willen R. van Drie van het Centraal Bureau voor Genealogie bedanken die ons de elektronische versie van verscheidene delen van het $\mathrm{Ne}$ derland's Adelsboek en het Nederland's Patriciaat leverde. Een minder uitgebreide Engelstalige versie van dit artikel werd als paper gepresenteerd op het XV World Congress of Sociology, te Brisbane, 7-13 juli 2002. 


\section{Literatuur}

Beekenkamp, G.G. (2002). President-directeuren, posities en patronen. Een studie naar de rekrutering van de leiders van de 250 ondernemingen in Nederland. Amsterdam: Aksant.

Bottomore, T. (1964, 1993). Elites and society. London and New York: Routledge.

Bruin, K. \& Schmidt, K. (1980). Zur Genealogie der Genealogie. Over het boekstaven van 'aanzienlijkheid' in het Koninkrijk der Nederlanden. Sociologische Gids, 26, 274-292.

Bruin, K. (1981). Kwesties van stand. Over de opname in de adelstand van Amsterdamse patriciërs in de $19^{\text {de }}$ eeuw. Sociologische Gids, 27, 110-140.

Bruin, K. (1992). Adelsbeleid in Nederland. Notities bij recente ontwikkelingen. Amsterdams Sociologisch Tijdschrift, 18, 119-133.

Cannadine, D. (1990). The decline and fall of the British aristocracy. New Haven \& London: Anchor Books.

Conze, E. (2000). Von Deutschem Adel. Die Grafen von Bernstorff im 20. Jahrhundert. Stuttgart/München: Deutsche Verlags-Anstalt.

Dronkers, J. (2000). De maatschappelijke relevantie van hedendaagse Nederlandse adel. Amsterdams Sociologisch Tijdschrift, 27, 233-268. Een Engelse versie is gepubliceerd in European Sociological Review (2003), 19, 81-99.

Dronkers, J. \& Hillege, S. (1997). Studentenverenigingen en de toegang tot de Nederlandse elites tussen 1960 en 1980. Amsterdams Sociologisch Tijdschrift, 24, 253-276.

Dronkers, J. \& Hillege, S.M.M. (1998). Board membership of traditional male fraternities and access to Dutch elites: a disappearing avenue to elite positions? European Sociological Review, 14, 191-204.

Dronkers, J., Schijf, H., Wolput, B. van \& Rupp, J. (1996). A university degree as gateway to the Dutch political and administrative elites from 1815 to 1960 . The Netherlands' Journal of Social Sciences, 32, 81-89.

Dronkers, J. \& Schijf, H. (2002). The transmission of elite positions among the Dutch nobility during the $20^{\text {th }}$ Century. Paper gepresenteerd tijdens de $10^{\mathrm{e}}$ Sociaal-wetenschappelijke Studiedagen, Amsterdam: 30-31 mei 2002.

Dronkers, J. \& Ultee, W.C. (1995). Verschuivende ongelijkheid in Nederland: sociale gelaagdheid en mobiliteit. Assen: Van Gorcum.

Ganzeboom, H.B.G., Treiman, D.J. \& Ultee, W.C. (1991). Comparative intergenerational stratification research: three generations and beyond. Annual Review of Socio$\log y, 17,277-302$.

Grange, C. (1996). Les gens du Botain Mondain 1903-1987. Paris: Fayard.

Hartmann, M. \& Kopp, J. (2001). Elitenselektion durch Bildung oder durch Herkunft? Promotion, soziale Herkunft und der Zugang zu Führungspositionen in der deutschen Wirtschaft. Kölner Zeitschrift für Soziologie und Sozialpsychologie, 53, 436-466.

Hillege, S \& Fennema, M. (1992). Studentencorpora en elitevorming. Amsterdam. Sociologisch Tijdschrift, 19, 96-117. 
Israel, J. (1995). The Dutch Republic. Its rise, greatness, and fall 1477-1806. Oxford: Oxford University Press.

Kuiper, Y. (1993). Adel in Friesland 1780-1888. Groningen: Wolters-Noordhoff/Egbert Forsten.

Lenski, G. (1984). Power and privilege. A theory of social stratification. Chapel Hill and London: The University of North Carolina Press.

Lieven, D. (1992). The Aristocracy in Europe 1815-1914. Houndsmills: Macmillan.

Pinçon, M \& Pinçon-Charlot, M. (1996). Grandes fortunes. Dynasties familiales et formes de richesse en France. Paris: Payot.

Reif, H. (ed.) (2001). Adel und Bürgertum in Deutschland. Entwicklungslinien und Wendepunkte im 20. Jahrhundert. Berlin: Akademie Verlag.

Rijken, S. (1999). Educational expansion and status attainment. A cross-national and overtime comparison. Utrecht: ICS.

Saint Martin, M. de (1993). L’Espace de la noblesse. Paris: Éditions Métaillé.

Schama, S. (1977). Patriots and liberators. Revolution in the Netherlands 1780-1813. New York: Alfred A. Knopf.

Schmidt, C. (1986). Om de eer van de familie. Het geslacht Teding van Berkhout 1500-1950; een sociologische benadering. Amsterdam: Bataafse Leeuw.

Wehler, H.-U. (1990). Europäischer Adel 1750-1950. Göttingen: Vandenhoeck \& Ruprecht. 


\title{
Blijvend gezag: continuïteit en verandering in de rechterlijke macht
}

\author{
Leny E. de Groot-van Leeuwen
}

\section{Elite en gezag}

Elites kunnen worden benaderd vanuit een functionele visie of vanuit een machtsvisie (vgl. Laeyendecker, 1984) ${ }^{1}$. In de functionalistische benadering ligt de nadruk op de manier waarop de elite een speciale taak vervult voor de samenleving. Dahrendorf (1961) noemt daarbij zeven instituties, waaronder het bedrijfsleven, de politiek en het recht; de toppen van die instituties vormen de maatschappelijke elite. In het perspectief van macht ligt de nadruk meer op de horizontale scheidslijn tussen elites en volk. Deze machtselite bestaat uit degenen wier beslissingen grote gevolgen hebben voor de samenleving (Mills, 1965).

De rechterlijke macht is zowel een functionele elite als een machtselite. In analyses van de rol van de rechterlijke macht in het staatsbestel, bijvoorbeeld in de trias politica, komt de nadruk vanzelf te liggen op de rechterlijke macht als functionele elite naast de andere (functionele) staatsmachten. Deze bijdrage vertrekt echter vanuit het begrip macht, en richt zich, in het voetspoor daarvan, op het gezag van de rechter.

Macht, gesteld in Weberiaanse termen, is de mate waarin bevelen (van personen en organisaties) worden opgevolgd. Dit opvolgen gebeurt door middel van (een mengsel van) dwang en gezag. Bij dwang kunnen in laatste instantie geweldsmiddelen worden ingezet. Gezag is de mate waarin bevelen (beslissingen) worden opgevolgd zonder dwang, omdat deze als juist en redelijk worden aanvaard (Ellemmers 1981: 279). Het begrip gezag wordt niet alleen gekoppeld aan het opvolgen van concrete besluiten, maar ook aan het op voorhand aanvaarden van beslissingen die nog niet genomen zijn (vgl. Hoekema \& Van Manen, 1994). Dan spreekt men veelal van legitimiteit en vertrouwen (in de politiek, in de rechter enzovoort).

In deze bijdrage worden beide vormen van gezag - het gezag in termen van concrete besluiten en handelingen en het gezag-op-voorhand - meegenomen. Daar waar het gaat om het gezag van de rechter in de rechtszaal is de eerste vorm aan de orde, terwijl het gezag van de rechterlijke macht als geheel (het maatschappelijk gezag) meer verbonden is met gezag-op-voorhand (legitimiteit). 
De macht van de rechter is niet onbeperkt. Soms wordt er toch gestaakt als de rechter het verboden heeft, soms zijn er te weinig cellen om gevangenisstraffen ten uitvoer te leggen en soms ontsnappen mensen aan opgelegde vorderingen (zie voor dit laatste Bruinsma, 1996 en Van Koppen \& Malsch, 1992). Toch is de macht van de rechter in individuele zaken evident. Ook is de macht van de rechter op maatschappelijk niveau in de twintigste eeuw volgens de literatuur sterk toegenomen (Wiarda, 1988; Van Koppen, 1990; WRR-rapport, 2002). Daarbij wordt met name gewezen op de invloed die de rechter heeft op wetgeving die het gevolg is van rechterlijke uitspraken (Rood, 1993; Veerman, 1996). Dat de rechterlijke macht een machtselite is zal dus geen verder betoog behoeven.

In hoeverre is de rechterlijke macht echter een gezagselite? Een strikt empirisch antwoord hierop zou kennis vragen over de mate waarin vonnissen en uitspraken worden opgevolgd op grond van meer dan de dreiging van deurwaarders, politieingrijpen en andere dwangmiddelen. Zulk empirisch-sociologisch onderzoek bestaat echter niet. Het lijkt echter ook zonder formeel onderzoek duidelijk dat de rechter een relatief groot gezag heeft en zijn uitspraken gezaghebbend zijn. Als 'de rechter heeft gesproken' betekent dat maatschappelijk iets - in ieder geval meer dan als een bedrijfsdirecteur een mening geeft. Ook in de staatsrechtelijke verhoudingen binnen de trias politica is dit het geval. De rechterlijke macht beschikt niet over dwangmiddelen (belastingheffing, leger enzovoort) ten opzichte van politiek en bestuur, maar de stem van de rechterlijke macht wordt van oudsher in de trias gehoord. Dit kan alleen zo zijn als gezag (legitimiteit) de grondslag is.

Aan dit gezag wordt door de rechterlijke macht zelf, maar ook door anderen, veel belang gehecht. Het zou immers maatschappelijk zeer schadelijk zijn als alle uitspraken van rechters tot de laatste snik door deurwaarder en politie zouden moeten worden afgedwongen. En in de trias-verhoudingen is gezag het enige machtsmiddel dat de rechter heeft. Deze zorg voor het gezag van de rechter klinkt steeds door in de discussies over de al dan niet vermeende partijdigheid van rechters en 'besmetting' van rechters door betrokkenheid van rechters met politiek en rechterlijk activisme (De Lange, 1993).

Hoe komt gezag tot stand? Hoe handhaaft de rechterlijke macht zijn gezagspositie? Hiervoor lijken drie centrale principes van belang. In de eerste plaats moet de rechter beslissingen nemen, en vooral ook motiveren, vanuit algemeen aanvaarde principes zoals de wet, redelijkheid en billijkheid; hij dient zorgvuldig te redeneren en een onpartijdige en onafhankelijke positie in te nemen (Tak \& Fiselier, 2002). De mate waarin dit nodig is en hoe dit moet worden vormgegeven hangt vanzelfsprekend af van de maatschappelijke omstandigheden. De door De Swaan (1982) veronderstelde overgang van een bevels- naar een onderhandelingshuishouding met steeds mondiger en kritischer burgers vraagt bijvoorbeeld om een betere en meer expliciete motivering van vonnissen (Witteveen, 1988). Deze maatschappelijke ontwikkelingen hebben invloed op de manier waarop de rechterlijke macht zijn gezag opbouwt en bewaart.

In de tweede plaats dienen de individuele rechters de mensen te zijn die voor 
deze functie de besten van de samenleving zijn (Drion, 1987). Wie 'de besten' verondersteld worden te zijn is eveneens afhankelijk van maatschappelijke ontwikkelingen. Zo kan bijvoorbeeld in termen van Webers ideaaltypen van gezag (traditioneel, rationeel en charismatisch) en in de geest van De Swaan worden verondersteld dat in de loop van de laatste vijftig jaar gezag meer op rationaliteit en minder op tradities gebaseerd is en dat daarmee de criteria voor wie de besten zijn ook verschoven zijn. Hierop wordt ingegaan in paragaaf 2 . In de derde plaats dient de rechterlijke macht als geheel een samenstelling te hebben die op de best mogelijke wijze voldoet aan maatschappelijke criteria. Dit wordt nader uitgewerkt in paragraaf 3.

\section{Selectie en carrière}

Wie in aanmerking komen om als de besten te worden beschouwd is afhankelijk van cultuur, 'tijdgeest' en omstandigheden. In andere culturen dan de onze beschouwt men als de besten bijvoorbeeld de mensen die het dichtst bij de goden staan. Of men ziet het goede voor een samenleving vooral verankerd in families in plaats van individuen; dan zijn functies erfelijk. Onze cultuur hanteert tegenwoordig vooral meritocratische criteria: mensen moeten individueel door prestaties laten zien dat zij in het bijzonder voor een functie geschikt zijn. Het inkomen van de ouders bijvoorbeeld behoort als zodanig geen rol te spelen.

In oorsprong werd de rechtspraak, in de vorm van bemiddeling bij een geschil of in de vorm van volksrechtspraak, uitgeoefend door mensen die dit niet als beroep hadden, de rechtspraak berustte bij het volk. Later werd de rechtspraak een specifieke deeltaak van geselecteerde individuen, vertegenwoordigers van het volk. En weer later werd het een fulltime taak (Van der Heijden 1965: 71). Vanaf de stichting van het Koninkrijk der Nederlanden in $\mathbf{1 8 1 5}$ is de rechtspraak een centrale overheidstaak. Sindsdien hebben vrijwel allen met deze rechtsprekende taak belast een juridische opleiding genoten. ${ }^{2}$

De eerste prestatie die heden ten dage geleverd moet worden alvorens rechter te worden is het afronden van de opleiding Nederlands recht aan een universiteit. In de loop van de twintigste eeuw is het aantal juristen aanzienlijk toegenomen. Dit is mede veroorzaakt door het laten vallen van de klassieke talen als vereiste voor toelating tot de juridische faculteiten (Van Eijck, 2002; voor België: zie Huysse \& Sabbe, 1997). Naast het aanbod van juristen speelt de vraag ernaar een belangrijke rol. Binnen de westerse samenlevingen is sprake van een juridiseringsproces, dat wil zeggen een groeiend aantal rechtsregels en een toenemend beroep op die regels. Dit brengt met zich mee dat steeds meer juristen nodig zijn voor wet- en regelgeving, handhaving en interpretatie van het recht en rechtshulpverlening.

Vergeleken met de advocatuur is de groei van de magistratuur gematigd. Terwij1 het aantal advocaten tussen 1950 en 2000 groeide van ongeveer 1.550 tot 11.050 groeide het aantal rechters in diezelfde periode van ongeveer naar 350 naar 1.700 . Overigens heeft Nederland opvallend veel minder rechters dan andere Europese landen. 
Er zijn twee wegen om rechter te worden in Nederland. Voor de Tweede Wereldoorlog kon men de zogeheten ambtelijke weg (of 'eigen kweek') bewandelen via het volontairschap op de griffie van een gerecht of men kon tot de rechterlijke macht toetreden via praktijkervaring buiten de rechterlijke organisatie in een ander juridisch beroep. Sinds 1957 kan men onmiddellijk na het afstuderen toegelaten worden tot de Raio-opleiding (rechterlijk ambtenaar in opleiding) of men kan, als men zes jaar ervaring heeft als jurist, direct tot de rechterlijke macht toetreden. De belangrijkste verschillen met de oude situatie zijn een centrale selectie, in plaats van een die bepaald werd door individuele magistraten (de presidenten van de gerechten) en de indeling van een stage in vaste onderdelen. Lange tijd was het beleid erop gericht om de rechterlijke macht voor de helft te laten bestaan uit mensen afkomstig van de Raio-opleiding en voor de andere helft uit de zogeheten buitenstaanders.

Geleidelijk aan kwam een verdere theoretische scholing van de grond. De Raioopleiding duurt zes jaar en is thans een mengsel van praktijk en theorie. De theorie bestaat uit cursussen in vaardigheden en op vakinhoudelijk gebied. Het praktijkdeel bestaat uit een stage van vier jaar bij de straf-, civiele en bestuurssector van de rechtbank en het parket van de officier van justitie en een buitenstage van twee jaar.

Welke toelatingscriteria worden gehanteerd? Analytisch vermogen, juridisch inzicht, besluitvaardigheid, het vermogen om onder druk goed te presteren, goede communicatieve vaardigheden en een zuiver beoordelingsvermogen zijn de kenmerken die in de voorlichting over de Raio-opleiding worden genoemd (www.rechtspraak.nl). Blijkens Tillema en Piepers (1995) hebben deze criteria ook een groot draagvlak in de rechterlijke macht zelf.

De sollicitatie naar een Raio-plaats dient vergezeld te gaan van een afschrift van de bul en een cijferlijst. De selectieprocedure bestaat verder uit een analytisch cognitieve test (een schriftelijke intelligentietest), een persoonlijk onderhoud, een assessment en een gesprek met de Raio-selectiecommissie waarin de sollicitant onder andere beoordeeld wordt op motivatie. Ook worden referenties gevraagd.

De selectieprocedure voor buitenstaanders verloopt via de 'Commissie aantrekken leden rechterlijke macht'. Naast de formele vereisten wordt expliciet genoemd dat men dient te beschikken over hoge capaciteiten op intellectueel en contactueel gebied, terwijl men bovendien wordt beoordeeld op besluitvaardigheid, evenwichtigheid en het vermogen tot samenwerken. Ook hier worden referenten benaderd. $\mathrm{Na}$ ontvangst van de sollicitatie vindt soms een gesprek plaats met de VoorselectieCommissie. Indien iemand wordt toegelaten tot het vervolg van de procedure vindt een psychologisch onderzoek plaats alsmede drie gesprekken met steeds twee leden van de commissie. Na afloop daarvan volgt het oordeel of de sollicitant, al dan niet onder voorwaarden, geschikt is voor een rechterlijke functie.

Het meritocratische gehalte van dit selectiestelsel is in de loop van twee eeuwen stelselmatig toegenomen. Het vervullen van een openbaar ambt was in Nederland tot aan het begin van de twintigste eeuw iets wat was voorbehouden aan degenen 
die zich dat konden veroorloven, in casu de aristocratie en de hogere burgerij. Zonder eigen vermogen was het niet mogelijk om van het rechtersinkomen te leven op een wijze die overeenkomt met de sociale status van de rechter (Pieterman, 1990). Dit wierp vanzelfsprekend een onoverkomelijke drempel op voor iedereen afkomstig uit niet-elitaire families.

Toch spelen ook bij de huidige selectie niet-meritocratische elementen nog altijd een rol. Het afronden van een universitaire studie is sowieso al meer voorbehouden aan studenten uit milieus waarin de ouders een meer dan gemiddeld inkomen en opleidingsniveau hebben. Studenten uit lagere milieus haken relatief vaker af, behalen lagere cijfers en doen langer over hun studie; dit is nog sterker het geval binnen de relatief elitaire studies zoals geneeskunde en rechten (CBS, 2001). Cultureel en financieel kapitaal van ouders speelt kennelijk nog steeds een rol (zie ook Koppen, 1991). Het feit dat rechtenstudenten gewoonlijk afkomstig zijn uit hogere milieus zal ook zijn effect hebben op het aandeel van allochtone studenten en daarmee op het aantal allochtone rechters. Er zijn geen precieze cijfers bekend, maar duidelijk is wel dat er een grote ondervertegenwoordiging is van allochtonen bij de rechterlijke macht (Pinedo, 2003).

De vraag die overblijft is of het meritocratisch primaat zich voortzet bij het carrièreverloop van rechters. Dit zou onderzocht kunnen worden door te kijken naar carrièreposities van rechters met verschillende achtergronden, bijvoorbeeld adel of burgerij, man of vrouw. Over dit laatste zijn gegevens bekend. Tabel 1 laat zien dat vrouwen nog steeds zijn ondervertegenwoordigd aan de top. Er bestaan geen aanwijzingen dat dit 'glazen plafond' op enigerlei wijze een meritocratische oorzaak zou kunnen hebben.

Tabel 1: Percentage vrouwen in drie functieniveaus in de rechterlijke macht ${ }^{3}$

\begin{tabular}{lrrrr}
\hline & 1974 & 1986 & 1990 & 2000 \\
\hline Top & 1,3 & 3,5 & 5,5 & 15 \\
Midden & 1,4 & 9,4 & 14,5 & 30 \\
Basis & 11,0 & 25,1 & 27,8 & 50 \\
\hline
\end{tabular}

Bron: Voor 1974, 1986, 199 I de Naamlijsten leden rechterlijke macht, bewerkt door De Groot-van Leeuwen 199I; voor 2000: eveneens de Naamlijst bewerkt t.b.v. Bruinsma 200 I.

Top: leden van (het parket) bij de HR, (coördinerend vice-)presidenten, plv. procureurs-generaal en hoofdofficieren. Midden: raadsheren, vice-presidenten bij de rechtbanken, kantonrechters, advocatengeneraal, plv. hoofdofficieren en officieren van justitie le kl. Basis: rechters en (subst.)officieren van justitie. 


\section{Een gezaghebbende samenstelling}

Voor opbouw en behoud van maatschappelijk gezag dient op collectief niveau vermeden te worden dat in de rechterlijke macht een cultuur ontstaat die tegenwoordig als te eenzijdig wordt beschouwd, bijvoorbeeld te plattelands of te grootstedelijk, te ouderwets, te masculien, te links of te blank. We willen dat de rechterlijke macht eenzijdig bestaat uit mensen met een hoge intelligentie, juridische vakkennis, inlevingsvermogen et cetera, maar - althans dat lijkt voorlopig de beste aanname - juist niet eenzijdig in andere, bijvoorbeeld politieke en culturele, zin. Dit criterium op collectief niveau staat op gespannen voet met de bovenvermelde criteria voor individuele rechters. Stel, bijvoorbeeld, dat vrouwen systematisch hogere cijfers op toetsen halen en dat deze cijfers van groot belang zijn bij de individuele selectie, dan bestaat de rechterlijke macht na een bepaalde periode voornamelijk uit vrouwen. Of stel dat de gemiddelde stemmer op D'66 gemakkelijker evenwichtig overkomt dan iemand die SP of Christen Unie stemt, dan bestaat de rechterlijke macht na een bepaalde periode uit onevenredig veel D'66-ers. Algemeen geformuleerd: door de kruiscorrelaties tussen gewenste criteria en andere kenmerken ontstaan op collectief niveau risico's van een te eenzijdig samengestelde rechterlijke macht, hetgeen systematisch afbreuk zal doen aan het gezag waarmee de rechterlijke macht spreekt. Daarom ga ik nu in op een aantal uit onderzoek bekende kenmerken van de samenstelling van de rechterlijke macht die relevant zijn voor haar gezag.

\section{Afkomst}

Uit de literatuur blijkt dat rechters in de negentiende eeuw uitsluitend uit de maatschappelijke toplaag werden gerekruteerd (o.a. Langemeijer, 1979; Pieterman, 1990). Tot en met het begin van de jaren zeventig van de vorige eeuw bestond het beeld dat de rechterlijke macht in afkomst uniform was (Schuyt 1975: 202). Cijfermatige gege-

Tabel 2: Aantal rechters en leden van het OM dat een adellijke titel voert

\begin{tabular}{lc} 
Jaar & Aantal \\
\hline 1950 & 40 \\
1966 & 26 \\
1970 & 22 \\
1974 & 21 \\
1979 & 19 \\
1986 & 18 \\
2000 & 13 \\
\hline
\end{tabular}

Bronnen: Naamlijsten leden rechterlijke macht 195I, 1974, 1979, 1986 en 2000 (bewerking De Grootvan Leeuwen 199I en extra aanvulling); voor 1970: Schenk, 1970. 
vens zijn er weinig, maar wel is vastgesteld dat het aandeel van de adel en het patriciaat in de Hoge Raad tussen 1848 en 1985 drastisch is afgenomen (Van Koppen en Ten Kate 1987: 56). Tevens is voor de periode van 1951 tot en met 2000 nagegaan hoeveel leden van de rechterlijke macht en het openbaar ministerie een adellijke titel voeren (vgl. De Groot-van Leeuwen, 1991). In 1951 waren dat 40 magistraten (10\%), in $198618(2 \%)$ en in $200013(0,5 \%)$. Zowel absoluut als relatief is er dus sprake van een sterke daling.

Als belangrijke indicator voor de sociale herkomst wordt veelal de beroepspositie van vaders genomen. Eind jaren zestig, begin jaren negentig en recent in 2000 zijn enkele metingen verricht naar de beroepsmatige achtergrond van de ouders van de leden van de rechterlijke macht, die helaas onderling niet goed vergelijkbaar zijn (zie tabel 3), doch die wel de conclusie rechtvaardigen dat een groot deel van de rechters afkomstig was en is uit gezinnen waarvan de vader werkt in een van de hogere beroepsgroepen (vgl. De Groot-van Leeuwen, 1991). Sinds 1991 zijn, indien naar het beroep van de ouders wordt gekeken, geen grote veranderingen opgetreden in de sociale herkomst van rechters (Bruinsma, 2001). Hierbij dient echter wel in het oog te worden gehouden dat voor de gehele beroepsbevolking geldt dat er in de loop van de twintigste eeuw een verschuiving heeft plaatsgevonden naar verhoudingsgewijs meer hogere beroepen.

Een andere belangrijke indicator voor de sociale herkomst is het opleidingsniveau van vaders. Eind jaren tachtig bleek uit interviews met 130 leden van de rechterlijke macht dat ruim een derde (35\%) van de geïnterviewden een vader had die een academische opleiding had genoten (De Groot-van Leeuwen, 1991). In aanmerking genomen dat deze vaders geboren zijn tussen het einde van de negentiende eeuw en

Tabel 3: Beroepsniveau van de vaders van de leden van de rechterlijke macht in percentages

\begin{tabular}{|c|c|c|c|c|}
\hline \multirow[t]{3}{*}{ Beroepsniveau } & \multicolumn{2}{|c|}{ (geen adm. rechters) } & $\begin{array}{l}\text { rechters, } \\
\text { om, raio's }\end{array}$ & rechters \\
\hline & 1968 & $1988 / 89$ & $199 \mid$ & 2001 \\
\hline & $\mathrm{n}=90$ & $n=130$ & $n=1007$ & $n=669$ \\
\hline Hoog & 60 & 51 & 62 & 60 \\
\hline Midden & 32 & 42 & 28 & 22 \\
\hline Laag & 8 & 8 & 7 & 8 \\
\hline Overig/geen opgaaf & - & - & 1 & 8 \\
\hline
\end{tabular}

Bronnen:Voor 1968Van der Land 1970; voor 1988/1989: De Groot-van Leeuwen 1991; voor 1991:Vrij Nederland-enquête 2 nov. 1991; voor 2001: Bruinsma 200I. De onderzoeken verschillen in populaties (rechters, rechters plus om etc.). Bovendien is de categorisering van 'hoog','midden' en 'laag' alleen in de onderzoeken uit I99I en 2000 precies dezelfde. 
Tabel 4: Hoogst voltooide opleiding van vaders van leden van de rechterlijke macht in percentages

\begin{tabular}{lrr} 
Opleiding & $\begin{array}{r}\text { rechters, } \\
\text { om, raio's } \\
\text { 1991 } \\
\mathbf{n}=1007\end{array}$ & $\begin{array}{r}\text { rechters } \\
\mathbf{n}=\mathbf{6 0 0}\end{array}$ \\
\hline Universitair & 36 & 32 \\
HBO/HTS/HEAO & 15 & 16 \\
HAVO/VWO/HBS & 12 & 18 \\
MAVO/MBO & 19 & 16 \\
Lager onderwijs & 18 & 17 \\
\hline
\end{tabular}

Bronnen: Voor 1991: Vrij Nederland 2 nov. 1991; voor 200I: Bruinsma 200I. De onderzoeken verschillen in populaties.

ongeveer 1930, een tijd waarin in Nederland slechts een à twee procent van de bevolking een academische titel behaalde, kan gesproken worden van een oververtegenwoordiging van het academische milieu. Later onderzoek laat zien dat, net als bij het beroepsniveau van de vaders tussen 1991 en 2001, geen belangrijke verschuiving heeft plaatsgevonden.

In het algemeen kan worden vastgesteld dat de rechterlijke macht naar milieu van herkomst geen afspiegeling is van de Nederlandse bevolking: de hogere strata uit de samenleving zijn oververtegenwoordigd. Dit zal niet snel veranderen omdat, zoals vermeld, tot in de jaren negentig, in Nederland weinig kinderen uit lagere milieus een juridische universitaire opleiding volgen, vergeleken met bijvoorbeeld een natuurwetenschappelijke universitaire studie.

Als we het ouderlijk milieu van rechters vergelijken met dat van advocaten, valt op dat de ouders van advocaten hoger zijn opgeleid. Dit blijkt uit tabel 5 die de opleiding van de ouders van rechters en advocaten laat zien. Als we hbo en universiteit samennemen, dan blijkt dat bij advocaten de vader en moeder voor 58 en 33 procent in deze categorie vallen, terwijl dit voor rechters slechts voor 48 en 18 procent opgaat. Dat is gedeeltelijk te verklaren uit het feit dat advocaten gemiddeld jonger zijn dan rechters: advocaten beginnen gewoonlijk hun loopbaan immers direct na hun academische studie, rechters op zijn vroegst zes jaar erna. Maar het is bovendien zo dat de selectie van juristen voor de rechterlijke macht op een meer meritocratische wijze geschiedt dan voor de advocatuur. 
Tabel 5: Hoogst voltooide opleiding van ouders van rechters en advocaten in percentages 2001

\begin{tabular}{lrrrr}
\hline & $\begin{array}{r}\text { adv. } \\
\text { vader } \\
\mathbf{n}=\mathbf{1 2 7 2}\end{array}$ & $\begin{array}{r}\text { rechter } \\
\text { vader } \\
\mathbf{n = 6 6 9}\end{array}$ & $\begin{array}{r}\text { adv. } \\
\text { moeder } \\
\mathbf{n = 1 2 7 2}\end{array}$ & $\begin{array}{r}\text { rechter } \\
\text { moeder } \\
\mathbf{n}=\mathbf{6 6 9}\end{array}$ \\
\hline Lager onderwijs & 13 & 17 & 17 & 26 \\
MAVO/MBO & 12 & 16 & 23 & 25 \\
HAVO/NWO/HBS & 14 & 18 & 23 & 26 \\
HBO & 19 & 16 & 19 & 11 \\
Universitair & 39 & 32 & 14 & 7 \\
\hline
\end{tabular}

Bron: Gunst \& Bruinsma 2002.

\section{Leeftijd en sekse}

De gemiddelde leeftijd van rechters was in 1951 alsook in 197453 jaar, in 1986 was dat 50 en in 200049 jaar; het is dus vooral tussen 1974 en 1986 dat een verjonging optrad. De deelname van vrouwen aan de rechterlijke macht steeg van 3 procent in 1970 tot 37 procent in 2000 (zie ook tabel 1). Leeftijd en sekse zijn direct zichtbaar in de rechtszaal en kunnen derhalve wel een zeker gezagsrisico voor de individuele rechter inhouden; het is voor velen niet makkelijk te accepteren dat over hun leven (inkomen, werk, gevangenisstraf) beslist wordt door iemand van net dertig.

\section{Politieke voorkeur}

Tabel 6 laat de percentages zien van de politieke voorkeur van de rechterlijke macht over de laatste dertig jaar. Wat direct opvalt is het verval van het CDA en de relatieve sterkte van D66 in de rechterlijke macht. Tevens zien we dat de rechterlijke macht wat betreft politieke kleur pluriformer is geworden: ging in 1970 nog 88 procent van de preferenties naar de grote drie partijen, in 2001 is dat nog slechts 54 procent. Verder valt op dat gedurende de linkse jaren zeventig de rechterlijke macht (met 36 procent voor de VDD en 31 procent voor het CDA) overwegend rechts was georiënteerd, terwijl gedurende de huidige tijd waarin vooral rechtse politiek spraakmakend is de rechterlijke macht als geheel een licht linkse oriëntatie heeft. Opmerkingen over klassenjustitie toentertijd en 'softies' tegenwoordig hebben wel enige empirische voet aan de grond. Men kan dit beschouwen als een stabiliserende factor in de samenleving, maar anderzijds lijkt het ook een risico voor het gezag van de rechterlijke macht.

\section{Professionele herkomst}

Discussies over de kwaliteit van rechters en rechtspraak en hoe de besten voor de rechterlijke macht te behouden, vonden ook al plaats in de negentiende en aan het 
Tabel 6: Politieke signatuur rechterlijke macht in procenten

Rechterlijke macht

1970

|99|

\section{$200 \mathrm{I}$ Verkiezingen 1998}

\begin{tabular}{lrrrr}
\hline CDA & 31 & 17 & 8 & 18 \\
VVD & 36 & 16 & 22 & 25 \\
PvdA & 21 & 19 & 24 & 29 \\
D66 & 11 & 39 & 17 & 9 \\
Groen Links & - & 4 & 12 & 7 \\
SP & - & - & 2 & 3 \\
Christen Unie & - & - & 2 & 3 \\
Overige/geen & 1 & 8 & 1 & 4 \\
\hline
\end{tabular}

Bronnen:Voor 1970: Van der Land; voor 1991: VN-enquête, 2 nov. 1991; voor 200I: Bruinsma, 2001.

begin van de twintigste eeuw (Pieterman, 1990). Onder meer tijdens de beraadslagingen van de Tweede Kamer over de Justitiebegroting van 1919 komen deze onderwerpen aan de orde, waarbij eveneens de weg waarlangs men toegang kreeg tot de rechterlijke macht een rol speelde: 'Door vele leden werd niet alleen uitbreiding maar ook verhoging van het bekwaamheidspeil (...) van het rechterscorps nodig geoordeeld. De methode van bezetting is niet geheel deugdelijk. In den regel verbinden jonge meesters in de rechten, die zich tot het rechterlijk ambt geroepen voelen of geen kans zien zich een advocatenpraktijk te verwerven zich aan de griffie. Is men eenmaal aan de griffie, dan wordt men, uitzonderingen daar gelaten, ook rechter. Maar bekwame jongelui, vooral als zij niet gefortuneerd zijn, zoeken een heenkomen elders. Een over veel levenservaring beschikkende magistratuur zou de civiele zowel als de strafrechtspraak op een heel wat hoger niveau weten te brengen dan die in hoofdzaak is gerecruteerd uit bureelambtenaren' (zie voor de discussies in latere jaren De Groot-van Leeuwen, 1991: 35 e.v.).

Hoewel het beleid vanaf de oprichting van de Raio-opleiding in 1957 erop gericht was om de helft van de rechters uit deze opleiding te rekruteren, is de groei van het aantal rechters vooral gerealiseerd door de instroom van buitenstaanders. Hun percentage steeg van 41 procent in 1951 via 55 procent in 1986 tot 72 procent van de rechterlijke macht in 2000. Zowel Groenendijk (1975) als Roos (1981) vreesde enige decennia geleden nog voor een ontwikkeling naar een steeds groter aandeel van intern opgeleiden (raio's), hetgeen zou leiden tot een meer eenvormige en verambtelijkte rechterlijke macht. Dit is blijkens de cijfers niet bewaarheid. Kijken we echter meer specifiek naar de werkervaring van de buitenstaanders dan valt op dat er een grote toename is van ex-ambtenaren (zie tabel 7). Via deze zijdeur is er toch sprake van een zekere 'verambtelijking'. 
Tabel 7: Vorige werkkring van rechters in percentages van de totale rechterlijke macht

\begin{tabular}{lrrrr}
\hline & 195 I & 1974 & 1986 & 2001 \\
\hline Advocatuur & 45 & 34 & 31 & 32 \\
(Semi-)overheid & 6 & 17 & 13 & 35 \\
(Universitair)onderwijs & 1 & 7 & 12 & 13 \\
Bedrijfsleven & 1 & 10 & 13 & 8 \\
Overig & 1 & 6 & 8 & 0 \\
Geen beroep (ex-griffiers, ex-raio's) & 46 & 26 & 22 & 12 \\
\hline
\end{tabular}

Bronnen: voor 195I, 1974, 1986 Naamlijst leden rechterlijke macht, bewerking De Groot-van Leeuwen, 1991; voor 200I: Bruinsma, 2000.

\section{Nevenfuncties en rechter-plaatsvervangers}

Veel rechters zijn naast hun hoofdfunctie maatschappelijk actief. Uit de tellingen van Eshuis (2001) blijkt dat vijftig procent van de 1453 geregistreerde niet-rechterlijke nevenfuncties van de leden van de rechterlijke macht bestaat uit juridische redacteurschappen, docentschappen en, vooral, quasi-rechterlijke functies zoals voorzitter of lid van scheidsgerechten, klachten-, geschillen- en bezwaarschriftencommissies. 44 procent van de geregistreerde nevenfuncties betreft voornamelijk bestuursfuncties. Eshuis vermeldt niet wat voor besturen dit betreft; het kunnen dus overwegend bestuurslidmaatschappen zijn van kleine verenigingen, maar ook van grote maatschappelijk sterk geprofileerde instellingen. Zes procent van de nevenfuncties betreffen functies in het bedrijfsleven of in de politiek. Zo zijn enkele rechters lid van de Eerste Kamer of van een gemeenteraad.

Het omgekeerde van nevenfuncties van rechters zijn de zogeheten 'externe rechter-plaatsvervangers'. ${ }^{4}$ Dit zijn juristen die hun hoofdfunctie buiten de rechterlijke macht hebben en die af en toe mee-rechtspreken, met name in de meervoudige kamers. De eerste keer dat in Nederland een verwijzing te vinden is naar rechterplaatsvervangers is in de Wet op de Zamenstelling van de Regterlijke Magt en het Beleid der Justitie uit 1827. De plaatsvervangers worden sinds de jaren zeventig van de vorige eeuw steeds vaker ingezet, wellicht omdat er vanaf die periode een forse toename van het aantal rechtszaken in ons land plaatsvond. Hoewel er bij elk gerecht externe plaatsvervangers zijn, lopen de aantallen en de mate van inzet sterk uiteen. Zo waren er in 1996 bij een bepaalde rechtbank 84 externe plaatsvervangers en bij een van de kantongerechten slechts één (Eskes \& De Groot-van Leeuwen, 1996). In 1995 waren er in totaal ongeveer 1300. Zij zijn afkomstig uit de wetenschap, het bedrijfsleven, de overheid en vooral uit de advocatuur.

Over nevenfuncties en rechter-plaatsvervangers hoeven wij ons niet in abstracto af te vragen of zij een risico vormen voor het gezag van de rechter. Daar wordt door de media en door verontruste burgers keer op keer nadrukkelijk op gewezen (o.a. door Burhoven Jaspers, 1997; Couwenhove \& Korver, 1997; Couwenhoven \& Korver, 
1999; Berts \& Voskuil, 1999; zie ook Huls, 2002), bijvoorbeeld als advocaten als rechter-plaatsvervangers mee-oordelen over ex-cliënten.

In 1994 veroorzaakte de rechtsgang met betrekking tot een conflict tussen een verzekeringsmaatschappij en een cliënt opschudding. Volgens deze cliënt zou er sprake geweest zijn van verstrengeling van belangen tussen het gerechtshof en de verzekeringsmaatschappij omdat vier advocaten van een bepaald kantoor rechterplaatsvervanger waren bij het hof, en hetzelfde kantoor de belangen van de verzekeringsmaatschappij behartigde. Sindsdien laat een groep verontruste burgers zich regelmatig kritisch uit over de nevenfuncties van rechters en over de positie van rechter-plaatsvervangers (zie www.sdnl.nl en het rapport Integriteit Rechterlijke macht, 1996). De kritiek richt zich veelal tegen het 'ons-kent-ons' onder advocaten en rechters. Zo wordt ook in HP/De Tijd van 22 november 2002 gesproken van een juristengilde waarbij 'de eensgezindheid tussen advocaten, rechters en juridische wetenschappers opvalt'. Dit beeld van de aaneengesloten machtselite is het diepste risico dat de positie van de rechterlijke macht tegenwoordig als gezagselite bedreigt.

\section{Conclusie}

Gezag is een kostbaar bezit van de rechterlijke macht. Gezag is gedeeltelijk gefundeerd in concreet handelen. Voor de rechterlijke macht betekent dat bijvoorbeeld: goede en goed gemotiveerde vonnissen en een klachtenregeling die laat zien dat de rechterlijke macht ontvankelijk is voor kritiek. Gezag is echter ook in belangrijke mate gefundeerd in personen, in wie er 'met gezag kan spreken', zowel op het niveau van individuele rechters als op het niveau van de rechterlijke macht als geheel. Op dit laatste heeft deze bijdrage zich vooral gericht.

We hebben gezien dat reeds voor de Tweede Wereldoorlog het besef ontstond dat de selectie voor de rechterlijke macht op strikt meritocratische principes zou moeten worden gebaseerd, en dat dit na de Tweede Wereldoorlog ook is gerealiseerd. Een secundair effect van deze meritocratische selectie zou kunnen zijn dat de rechterlijke macht als geheel een samenstelling zou kunnen krijgen die als ongewenst wordt beschouwd doordat bepaalde soorten kandidaten, bijvoorbeeld vrouwen of CDA'ers, systematisch beter op individuele tests scoren. Lang niet alle van deze 'variabelen van mogelijke eenzijdigheid' zijn empirisch onderzocht. De voor deze conclusie interessantste zijn:

- Een eenzijdige, relatief elitaire, afkomst. Dit tot nu toe relatief stabiele verschijnsel roept geen maatschappelijke discussie op. Blijkbaar vinden we het zelfs in egalitair Nederland niet erg dat er een bovenlaag bestaat die mensen op hoge maatschappelijke posities voortbrengt, als die mensen maar werkelijk naar meritocratische maatstaven de besten zijn.

- Een lichte eenzijdigheid in politieke voorkeur. Gedurende de 'linkse' jaren zeventig van de vorige eeuw had de rechterlijke macht een lichte hang naar rechts; tegenwoordig is de samenstelling in dit opzicht pluriformer, maar met 
een lichte tendens naar links - in beide gevallen net tegen de maatschappelijke trend in dus. Dit maakte in beide gevallen een maatschappelijke discussie los.

- Een personele uitwisseling met andere maatschappelijke sectoren, zoals het bedrijfsleven, de advocatuur, de overheid en de politiek. Deze roept een minder brede discussie op, maar de kritiek is wel veel feller...

Het beeld van de rechterlijke macht als 'equilibrium elite' lijkt hier passend (De Groot-van Leeuwen, 1991). Het vormt maatschappelijk geen probleem dat de meritocratische selectie resulteert in een enigszins elitaire afkomst van rechters. Maar het 'equilibrium' moet die elite vervolgens wel waarmaken, zonder politieke eenzijdigheid en zonder al te veel vermenging met andere maatschappelijke sectoren. De trias politica is blijkbaar niet alleen een belangrijk principe voor abstracte staatsrechtelijke verhoudingen, maar heeft ook, als het gaat om concrete selectie, samenstelling en gedrag van de rechterlijke macht de maatschappelijke voorkeur.

\section{Noten}

1. In deze bijdrage worden onder de rechterlijke macht verstaan de rechters bij de rechtbanken, de kantonrechters, de raadsheren bij de hoven en de Hoge Raad. Indien incidenteel ook de leden van het Openbaar Ministerie $(\mathrm{OM})$ worden bedoeld, dan staat dit expliciet vermeld.

2. Lekenrechtspraak is in Nederland uitzonderlijk.

3. Zie voor de verschillen tussen de onderzoeken uit diverse jaren in deze bijdrage aangehaald o.a. De Groot-van Leeuwen, 1992.

4. Er bestaan ook interne rechter-plaatsvervangers, dat zijn collega-rechters die op een ander gerecht dan daar waar zij vast werken een helpende hand bieden.

\section{Literatuur}

Berts, D. \& Voskuil, B. (1999). Rechters maken tijd voor omstreden bijbanen. Nieuwe Revu, 45, 20-24.

Burhoven Jaspers, N.C. (1997). Rapport Integriteit Rechterlijke Macht (IRM-rapport); de rechterlijke macht: een gilde op drift! Ars Aequi, 46/3, 149-150.

Bruinsma, F. (1996). Korte gedingen: een rechtssociologisch verslag. Zwolle: Tjeenk Willink.

Bruinsma, F. (2001). Rechters in Nederland, Een NJB-enquête. NJB, 40, 1925-1934.

CBS (2001). htpp://www.cbs.nl/nieuws/artikelen 0784k.htm

Couwenhoven R. \& Korver, H. (1997). Rem's recht zegeviert! De Telegraaf, 12 juli.

Couwenhoven R. \& Korver, H. (1999). Alle rechters gewraakt! De Telegraaf, 6 januari.

Dahrendorf, R. (1961). Gesellschaft und Freiheit. München: Piper \& Co Verlag.

Drion, H. (1987). Eliteproblemen. Amsterdam: Bert Bakker.

Eijck, K. van, Haan, J. de \& Knulst, W. (2002 ). Snobisme hoeft niet meer. Mens en Maatschappij, 77, 153-177.

Ellemers, J.E. (1981). Macht. In L. Rademaker (red.), Sociologische grondbegrippen (pp. 276-297). Utrecht/Antwerpen: Het Spectrum. 
Eshuis, R.J.J. \& Dijkhoff, N. (2000). Nevenfuncties zittende magistratuur. Den Haag: WODC.

Eshuis, R.J.J. (2001). De nevenfuncties van vaste rechters en plaatsvervangers. Den Haag: WODC.

Eskes, T.K.A.B. \& Groot-van Leeuwen, L.E. de (1996). De plaatsvervanger tussen rechtspraak en opspraak. Trema, 7, 197-201.

Groenendijk, C.A. (1975). De rechterlijke macht in Nederland: tussen balie en bureaucratie. Beleid en Maatschappij, nummer 151-165.

Groot-van Leeuwen, L.E. de ( 1991). De rechterlijke macht in Nederland, samenstelling en denkbeelden van de zittende en staande magistratuur. Arnhem: Gouda Quint.

Groot-van Leeuwen, L.E. de (1992). De derde macht in beeld gebracht; twee publikaties vergeleken. Tijdschrift voor Criminologie, 34, 156-161.

Groot-van Leeuwen, L.E. de, Jong, P. de, Pieterman, R. \& Seters, P. van (1993). Het gezag van de rechter. Amsterdam: SISWO.

Groot-van Leeuwen, L.E. de (200o). De rechterlijke macht in beweging. In R. Schwitters, Recht en samenleving in verandering (pp. 109-125). Deventer: Kluwer.

Gunst, J. \& Bruinsma, F. (2002). Advocaten in Nederland, Een NJB-enquête. NJB, 21, 1015-1023.

Heijden, E.J.J. van der (1965). Aantekeningen bij de geschiedenis van het oude vaderlandse recht. Nijmegen/Utrecht: Dekker \& Van de Vegt.

Hoekema, A.J. \& Manen, N.F. van (1994). Typen van legaliteit: recht en maatschappelijke orde in de twintigste eeuw. Deventer: Kluwer.

Huls, N.J.H. (2002). De politieke rol van de rechter. Lezing Dies natalis, Erasmus Universiteit Rotterdam.

Huysse, L. \& Sabbe, H. (1997). De mensen van het recht. Leuven: Van Halewyck.

Koppen, J.K. (1991). Een kwestie van discipline; over de externe democratisering van het wetenschappelijk onderwijs. Amsterdam: Thesis.

Koppen, P.J. van \& Kate, J. ten (1987). Tot raadsheer benoemd, anderhalve eeuw benoemingen in de Hoge Raad der Nederlanden. Arnhem: Gouda Quint.

Koppen, P.J. van (1990). The Dutch Supreme Court and parliament: political decisionmaking versus nonpolitical appointments. Law and Society Review, 24(3).

Koppen, P.J. van \& Malsch, M. (1992). Hoe de verliezer wint. NJB, nummer, 1101-1104. Laeyendecker, L. (1984). Sociale verandering: problemen en theorieën. Boom: Meppel.

Land, R. van der (1970). Een enquête onder de Nederlandse rechterlijke macht. Ars Aequi, dec, 524-532.

Lange, R. de (1993). Rechterlijk activisme en het gezag van de Europese rechter. In L.E. de Groot-van Leeuwen, P. de Jong, R. Pieterman \& P. van Seters, Het gezag van de rechter (pp. 59-84). Amsterdam: SISWO.

Langemeijer, G.E. ( 1979). Taak en opleiding van de rechter. Gent: naam uitgever.

Mills, C.W. (1956). The power elite. New York: Oxford University Press.

Pieterman, R. (1990). De plaats van de rechter in Nederland 1813-1920. Arnhem: Gouda Quint.

Pinedo, D. (2003). Blanke bastions. NRC, 29 januari. 
Rood, M.G. (red.) (1993). Rechters en politiek, nationale en internationale beschouwingen. Zwolle: Tjeenk Willink.

Roos, N.H.M. (1981). Juristerij in Nederland. Sociale ontwikkeling in de opleiding en de beroepen van juristen. Deventer: Kluwer.

Schenk, W. (1970). Telt de rm onevenredig veel 'adellijke' leden? NJB, nummer, 677678.

Schuyt, C.J.M. (1975). Recht en samenleving. Assen: Van Gorcum.

Swaan, A. de (1982). Uitgaansbeperkingen en uitgaansangst; de verschuiving van bevelshuishouding naar onderhandelingshuishouding. In A. de Swaan, De mens is de mens een zorg. Opstellen 1971-1981 (pp. 81-115). Amsterdam: Meulenhoff.

Tak, P.J.P. \& Fiselier, J.P.S. (2002). Duitsland-Nederland en de afdoening van strafzaken. Nijmegen: Wolf Legal Publishers.

Tillema, M.E.H. \& Piepers, C.A. (1995). Het functieprofiel van de rechter bezien vanuit psychologisch perspectief. Amsterdam: LTP.

Veerman, G.J. (1996). Het wetgevingsproces. In J. Griffiths (red.), De sociale werking van het recht. Een kennismaking met de rechtssociologie en de rechtsantropologie (pp. 797802). Nijmegen: Ars Aequi Libri.

Wiarda, G.J. (1963; 1988). Drie vormen van rechtsvinding. Zwolle: Tjeenk Willink.

Witteveen, W. (1988). De retoriek in het recht. Over retorica en interpretatie staatsrecht en democratie. Zwolle: Tjeenk Willink.

WRR-rapport (2002). De toekomst van de nationale rechtsstaat. 's-Gravenhage. 



\title{
Toetreding en terugdringing \\ De opkomst van een lokale politieke elite'
}

\author{
Jan Rupp, John Schuster en Huibert Schijf
}

\section{Inleiding}

De komst van grote groepen migranten naar West-Europa heeft niet alleen geleid tot nieuwe transnationale verbindingen, maar ook tot veranderingen in de politieke en sociale ruimte op lokaal en nationaal niveau binnen de nieuwe migratielanden. De politieke participatie in de nationale en lokale politiek door allochtonen heeft zich in de jaren tachtig en negentig in Europa tot een belangrijk politiek issue ontwikkeld. Als maatschappelijk geaccepteerde oplossing hebben deze nieuwe migranten in landen als Denemarken, Engeland en Nederland lokaal kiesrecht gekregen, zonder een nieuwe nationaliteit te moeten aannemen. Migranten met de nationaliteit van het migratieland hadden uiteraard ook daarvoor al het recht om te stemmen of gekozen te worden op lokaal en nationaal niveau.

Europese landen met een koloniaal verleden, zoals Frankrijk, Engeland en Nederland, kennen een lange traditie van immigratie en vestiging van personen uit hun voormalige koloniën. Deze groepen bezaten enige kennis over het land waar ze naar toe verhuisden en in veel gevallen spraken ze ook de taal heel behoorlijk. Voor de meeste migranten uit Indonesië was het vanaf het begin duidelijk dat ze in Nederland zouden blijven. Surinamers waren aanvankelijk ambivalenter over hun permanente vestiging. Andere groepen, de grootste uit Marokko en Turkije, kwamen in de jaren zestig en zeventig als zogenaamde gastarbeiders en hoewel de motieven wellicht divers waren, was bij iedereen de economische drijfsfeer dominant. Veel van deze mannelijke migranten waren gerekruteerd als contractarbeiders. Ze waren vaak laagopgeleid, zonder kennis van de Nederlandse taal en cultuur, en ze werden meestal tewerkgesteld in laagbetaalde banen in de industrie. De gastarbeiders verlieten Marokko of Turkije omdat zij hun positie thuis wilden verbeteren, niet met het voornemen om zich hier te vestigen. Uiteindelijk zijn ze, dikwijls om economische redenen, toch op grote schaal gebleven en vele gezinnen zijn sindsdien herenigd.

Hoewel veel van deze migranten, ook in de tweede en derde generatie, nog ster- 
ke banden onderhouden met hun thuisland, zoals bijvoorbeeld blijkt uit het hoge percentage transnationale huwelijken dat binnen deze groepen wordt gesloten (Hooghiemstra, 2003), hebben verreweg de meeste gezinnen met hun hier geboren kinderen zich voorgoed in Nederland gevestigd. Inmiddels heeft zich binnen de Surinaamse gemeenschap een goed opgeleide middenklasse ontwikkeld die op diverse maatschappelijke terreinen als bestuurlijke professionals werkzaam is; in voorlopig mindere mate zien we ook binnen de Turkse en Marokkaanse gemeenschap een middenklasse ontstaan die zich ongetwijfeld verder zal uitbreiden. Maar waarschijnlijk staat bij hen op dit moment economisch succes hoger in aanzien dan het slagen in bestuurlijk of politieke posities. Allochtone politici, waaronder gemeenteraadsleden, zijn een voorbeeld van dit gestage proces van inburgering, politieke betrokkenheid en stijgende mobiliteit. Langzaam ontstaat een lokale politieke elite van oorspronkelijk allochtone afkomst. Sommigen hebben inmiddels de Nederlandse nationaliteit, anderen niet.

Verruiming van het lokale kiesrecht en het handelen van politieke partijen hebben daarbij een belangrijke rol gespeeld. Misschien hopend op extra electoraal succes, begonnen vrijwel alle partijen in het begin van de jaren tachtig vertegenwoordigers uit allochtone groepen in de grote steden te rekruteren en werden deze op verkiesbare plaatsen bij gemeenteraadsverkiezingen gezet. Tussen 1978 en 1998 zijn in die steden 45 allochtone gemeenteraadsleden gekozen. Hun electoraal succes was aanvankelijk aanzienlijk, maar bij de laatste verkiezing in 2002 viel op dat veel minder personen met een allochtone achtergrond op verkiesbare plaatsen stonden. Misschien is bij partijen het enthousiasme weer bekoeld of blijkt het veel moeilijker dan gedacht om zulke raadsleden succesvol binnen een fractie te laten opereren. Overigens zijn verscheidene allochtone gemeenteraadsleden alsnog via voorkeursstemmen gekozen. In dit artikel we stellen ons twee vragen. De eerste is in hoeverre deze nieuwe allochtone raadsleden zich als politieke nieuwkomers onderscheiden van eerdere nieuwkomers in de gemeenteraden van de vier grote steden. Gedurende de laatste anderhalve eeuw zijn door wettelijke veranderingen in het stemrecht, maar ook door grote maatschappelijke ontwikkelingen, steeds nieuwe groepen tot die gemeenteraden toegetreden. Steeds had de toetreding van nieuwe groepen een terugdringing van gevestigden tot gevolg.

De tweede vraag is in hoeverre deze nieuwe allochtone raadsleden verschillen van hun autochtone tegenvoeters wat betreft hun sociale achtergrond en gebondenheid met een maatschappelijke achterban. Zo richten we ons op hun rekrutering en hun individuele problemen met identiteit, hun moeilijkheden om zich aan te passen en goed te functioneren in een dominant Nederlandse omgeving met zijn impliciete regels omtrent het verwerven van prestige en met een politieke cultuur van langdurig onderhandelen om ten slotte een doel te bereiken waarover consensus bestaat. Ook hun eigen ambivalente positie tegenover hun eigen etnische groep speelt daarbij een rol. Sommigen ondervinden dat problemen van migrantengroepen van secundair belang worden geacht in vergelijking met 'echte' problemen, zoals Schiphol of een ziekenhuisfusie, waar migranten minder affiniteit mee heb- 
ben; ze worden soms ook wel bekritiseerd als ze een specifiek migrantenprobleem aan de orde willen stellen. Traditioneel machtige organisaties als ziekenhuisorganisaties blijken meer invloed te hebben dan migrantenorganisaties. Aan de andere kant worden allochtone raadsleden bekritiseerd door migrantengroepen omdat ze

niet kunnen voldoen aan de hooggespannen verwachtingen die ze hebben van 'hun' vertegenwoordigers.

Ten slotte zijn toekomstperspectieven na hun lidmaatschap van belang. We veronderstellen dat het lid zijn van een gemeenteraad in een van de vier grote steden mogelijkheden biedt tot het verwerven van sociaal en politiek kapitaal (vgl. Bourdieu, 1989: 120-140) dat tijdens en na het lidmaatschap kan worden aangewend om een nieuwe carrière te verwezenlijken. We zullen de vraag in hoeverre dat lukt en of er verschillen zijn tussen allochtone en autochtone raadsleden verder onderzoeken.

\section{Gegevens}

De keuze voor de vier grote steden is bepaald door het feit dat hun gemeenteraden een aanzienlijke groep politici van allochtone afkomst kennen. In Amsterdam achttien, in Den Haag acht, in Rotterdam acht en ten slotte in Utrecht tien. Tot de categorie der allochtonen worden gerekend de vier belangrijkste doelgroepen van het minderhedenbeleid: Surinamers, Antillianen en Arubanen, Turken en Marokkanen. Op twee personen na (een Ghanees in Amsterdam en een Griek in Utrecht) behoren alle allochtone politici die tussen 1978 en 1998 zijn gekozen tot een van deze doelgroepen. Van hen zijn er acht Marokkanen, achttien Surinamers, zestien Turken en is slechts één Antilliaan gekozen.

Voor het onderzoek zijn zoveel mogelijk gegevens over alle 467 personen verzameld die tussen 1980 en 1998 in de gemeenteraad van de vier grote steden zijn gekozen. Het betreft zowel biografische gegevens (geboortedatum en geboorteplaats, opleiding, studierichting, studieplaats en beroep) als politiek-biografische gegevens (termijn(en) van het raadslidmaatschap en eventueel wethouderschap) van raadsleden van allochtone en autochtone afkomst in de onderscheiden periode. Al deze (voormalige) raadsleden (voorzover zij nog in leven zijn en van wie het adres bekend is) zijn daarop schriftelijk en telefonisch benaderd met het verzoek om de reeds verzamelde gegevens te controleren en een aantal vragen te beantwoorden over hun eigen levensloop en die van hun ouders. De vragen zijn geclusterd rond de volgende thema's: godsdienst/levensbeschouwing; opleiding; partijpolitieke functies; beroepsloopbaan vóór, tijdens en na het raadslidmaatschap; en nevenfuncties en maatschappelijke activiteiten tijdens het raadslidmaatschap. Met een kleinere groep zijn daarna gesprekken gevoerd.

\section{Veranderingen in de Gemeentewet tussen I85 I-2002}

Grote veranderingen in de sociale compositie van gemeenteraden werden mogelijk door de wetgeving omtrent gemeenteraadsverkiezingen. Er zijn drie lange periodes 
te onderscheiden: 1851-1919, 1919-1985 en 1985-heden. In 1851 werd een nieuwe Gemeentewet aangenomen. De wet was onderdeel van wetgeving omtrent nationale, provinciale en lokale overheden. Er werden rechtstreekse verkiezingen geïntroduceerd voor gemeenteraadsleden en er kwam een actief censuskiesrecht. De bedoeling van de nieuwe gemeentewet was om de macht van lokale regentenfamilies, die soms al eeuwen bestuurden, drastisch in te perken. Het terugdringen van die groepen verliep niet overal met hetzelfde succes. In kleinere gemeente waren regenten meestal in staat om deze veranderingen het hoofd te bieden en daar bleven de gevolgen van de nieuwe wet nog decennia erg beperkt (Van Sas, 1998: 248-253). Maar in een stad als Rotterdam maakte een nieuw aantredende economische elite, waaronder veel toekomstige havenbaronnen, als gemeenteraadsleden van de nieuwe mogelijkheden gebruik om een moderne infrastructuur voor de stad aan te leggen (Callahan, 1981). Deze nieuwkomers waren politiek niet hecht georganiseerd, maar veelal lid van kiesverenigingen, zoals gebruikelijk aan het eind van de negentiende eeuw. In de steden waar de nieuwkomers electoraal succes hadden, konden ze belangrijke initiatieven voor hun stad ontplooien. Het eigenbelang van de nieuwkomers viel daarbij vaak samen met het belang van de stad.

In de decennia daarna volgden diverse uitbreidingen van het censuskiesrecht waardoor steeds ruimere groepen het stemrecht verwierven. Vertegenwoordigers van de lagere middenklasse en de arbeidersklasse traden tot de raden toe, maar erg vaak gebeurde dat toch nog niet. De eerste arbeider in de Amsterdamse gemeenteraad in 1891 baarde opzien: 'Te midden der heeren met de hooge hoeden en de pelsjassen werkte deze figuur als een verfrisching en zijn hartig woord vibreerde meenig maal na in de Amsterdamse volksbuurten', meende Het Volk (geciteerd in Hofland, 1998: 74). De gemeenteraad van Amsterdam kende rond 1900, net als die van Rotterdam, echter vooral veel vertegenwoordigers uit het bedrijfsleven, naast redelijk veel raadsleden met een vrij beroep (Hofland, 1998: 70). In Den Haag waren er tussen 1889-1919, naast raadsleden met een achtergrond in handel en verkeer (25 procent) veel leden die overheidsposities vervulden, zo rond de 27 procent (Stokvis, 1987: 320).

Na de Eerste Wereldoorlog werd het algemeen kiesrecht ingevoerd en verkregen bovendien vrouwen voor het eerst het recht om te stemmen en zich kandidaat te stellen. Hun verkiezing had onvermijdelijk tot gevolg dat het aantal mannelijke gemeenteraadsleden werd teruggedrongen, want de omvang van de gemeenteraden van Amsterdam, Den Haag, Rotterdam en Utrecht is in de loop der jaren nauwelijks toegenomen. Overigens waren er aanvankelijk nog maar weinig vrouwelijke gemeenteraadsleden (Schoemaker, 1993). In 1935 was slechts één procent van alle gemeenteraadsleden vrouwelijk, hoewel in de vier grote steden dat percentage rond de vijf procent lag. Er is nooit een partij opgericht die exclusief de belangen van vrouwen vertegenwoordigde: alle vrouwelijke gemeenteraadsleden waren lid van gevestigde politieke partijen, hoewel de linkse partijen (onder andere de SDAP) meer vrouwelijke gemeenteraadsleden telden dan de christelijke partijen (Schoemaker, 1993: 212). 
Van vrouwelijke gemeenteraadsleden werd verwacht dat ze zich 'ingetogen' gedroegen en hun aandacht vooral richtten op zaken als onderwijs, gezondheidszorg en huisvesting maar de toon van de politieke debatten veranderde nauwelijks. Vrijwel alle vrouwen hadden immers al bestuurlijke ervaring opgedaan, vaak binnen de SDAP. Het toenemend aantal vertegenwoordigers uit de arbeidersbewegingen en vakbeweging veranderde soms weliswaar de toonzetting van het debat maar de bestuurlijke en politieke ervaring van deze nieuwkomers was meestal behoorlijk groot, zodat men op de hoogte was van regels en procedures. Vanaf 1902 leverde de SDAP raadsleden in Amsterdam, maar deze voormalige arbeiders hadden in de partij zelf of in de vakbond al functies vervuld en ervaring opgedaan (Hofland, 1998: 75). Ze moesten zich misschien aanpassen aan een specifieke cultuur van vergaderen en omgangsvormen in de raad, bestuurlijk en politiek waren ze zelden een onbeschreven blad.

In de twintigste eeuw veranderde de samenstelling van gemeenteraden dramatisch. In Amsterdam was er bijvoorbeeld een snelle daling van leden uit de economische elites: van vijftig procent in 1854 naar negen procent in 1929 (Hofland, 1998: 70), terwijl het aandeel lagere middenklasse, professionele politici en vakbondsvertegenwoordigers aanzienlijk steeg (van nul procent in 1854 naar 36 procent in 1929). In plaats van burgers georganiseerd in kieskringen die hun eigen belang zagen als het belang van de gehele stad, kwamen er professionele politici die het ideologische programma van hun politieke partij en haar kiezers vertegenwoordigden. Los van enkele lokaal specifieke verschillen is dezelfde ontwikkeling ook te zien in Rotterdam (Baggerman, 1994), Den Haag (Schoemaker, 1993) en Utrecht tijdens het Interbellum.

Het is echter niet waarschijnlijk dat het zich terugtrekken van de economische elites uit het gemeentelijk bestuur alleen kan worden verklaard door de komst van nieuwe groepen. Veel leden van de hogere burgerij hadden Amsterdam al verlaten of stonden op het punt dat te doen, en verhuisden naar de landelijke gemeentes op spoorafstand van Amsterdam. Dit terugtrekken uit de raad zou heel goed kunnen worden gezien als een aanwijzing dat deelname aan de lokale politiek voor hen van minder belang was geworden. De lokale elites werden nationale elites die veel meer geïnteresseerd raakten in het vertegenwoordigen van hun belangen op nationaal niveau. In de periode 1919-1985 zien we dus een geleidelijke terugdringing van de groepen die daarvoor domineerden: de liberale hogere sociale groepen in de steden. Daarentegen komen vakbondsbestuurders en arbeiders meer naar voren, terwijl heel geleidelijk vrouwen mannen gaan vervangen. De Tweede Wereldoorlog heeft weinig invloed op de wetgeving aangaande gemeenteraden gehad.

Pas in 1985 veranderde die wetgeving door immigranten het kiesrecht op lokaal niveau te verlenen. Voor 1985 waren er al enkele kandidaten met een immigrantenachtergrond gekozen, het waren met name Nederlanders met een Surinaamse achtergrond die raadslid werden. Deze summiere schets van enkele historische ontwikkelingen maakt duidelijk dat net als de politieke samenstelling van de raad ook de sociale samenstelling voortdurend aan veranderingen onderhevig is geweest. Het 
is daarom goed zich te realiseren dat de opname van allochtone gemeenteraadsleden slechts een van de stappen is in dit proces van een voortdurende verschuiving van de samenstelling van gemeenteraden. Wel ondervinden nieuwkomers soms problemen met hun inpassing in een bestaande politieke cultuur, maar nog meer met de tegenstrijdige verwachtingen die door hun partij- en fractiegenoten en hun achterban worden gekoesterd. In deze laatste periode zien we een terugdringing van (blanke) autochtone personen door (gekleurde) personen met een allochtone achtergrond.

Gedurende deze lange periode zien we ook veranderingen in de opvattingen omtrent het lidmaatschap. In de periode na 1919 staat volksvertegenwoordiging op de voorgrond. Het was een achterban van maatschappelijke/politieke organisaties uit het maatschappelijke middenveld die centraal stonden bij de vertegenwoordiging van raadsleden: politieke partijen, vakbonden, werkgeversorganisaties, kerkelijke organisaties en semi-overheidsorganisaties, om enkele te noemen. Zo vervulde van de 136 Haagse raadsleden in de periode 1919-1940 ruim een derde voor, tijdens of na het lidmaatschap een staatkundige functie. Een zetel in de Provinciale Staten (26) van Zuid-Holland of een Tweede-Kamerlidmaatschap (23) hadden de voorkeur (Van Doorn 2002: 205). In de andere drie steden zijn vergelijkbare patronen te zien. Gemeenteraadsleden verschilden onderling in de achterban die ze vertegenwoordigden, die dikwijls langs de afzonderlijke zuilen verliep. In de huidige periode zijn deze verbindingen losser geworden en is in Nederland sprake van een sterke individualisering. Het lidmaatschap valt nu ook, of vooral, te zien als een van de mogelijkheden om als individu maatschappelijk te stijgen. De vraag is of allochtone raadsleden evenzeer aan dit stijgingspatroon meedoen als autochtone raadsleden.

\section{De rekrutering van allochtone kandidaten}

De eerste allochtonen die in de gemeenteraden van de vier grote Nederlandse steden werden gekozen na de inwerkingtreding van de nieuwe wet waren allen afkomstig uit Suriname: Amzand en Balai (PvdA) en Oedayraj Singh Varma (Links Akkoord, CPN, PPR en PSP) in Amsterdam; Chandoe en Ramlal in Den Haag; Woei A Tsoi en Oedairam (PvdA) in Rotterdam en Rambocus in Utrecht. Leden van andere allochtone groepen kwamen pas in de verkiezingen daarna in de raden. In Amsterdam was dat al bij de daaropvolgende verkiezingen het geval met de entree van Karaman-Ince (Links Akkoord). In Den Haag duurde het tot 1994 voor Haifi in de raad werd gekozen. In Rotterdam waren Woei A Tsoi en Oedairam tot 1998 de enige raadsleden van allochtone afkomst. In dat jaar werden zij afgelost door Bayraktar, Çelik, Esser en Salhi (PvdA), Erdal (CDA) en Bourzik en Daal (Groen Links). En in Utrecht bleef Rambocus het enige allochtone lid van de gemeenteraad tot aan de verkiezing van Najib (PvdA) en Karaoglan-Sengüller (Groen Links) in 1990.

Anno 2003 zijn politici van allochtone afkomst niet meer weg te denken uit de raadzalen van de vier grote gemeenten. Het lukte hen steeds beter om een plaats te bemachtigen op de kandidatenlijst en (al dan niet via voorkeurstemmen) te worden 
gekozen in de gemeenteraad. Ging het in 1978 nog om twee personen, in 1998 werden in totaal 31 allochtonen in de gemeenteraden van Amsterdam (11), Rotterdam (8), Den Haag (6) en Utrecht (6) gekozen. Al deze raadsleden zijn gerekruteerd door gevestigde politieke partijen en er is tot nu toe geen enkele migrantenpartij tot een gemeenteraad toegetreden. Wel is het zo dat er grote verschillen tussen de partijen zijn. Zo zijn van de 45 hier beschreven raadsleden met een allochtone achtergrond er vijftien lid van Groen Links en negentien van de PvdA, partijen die in de grote steden domineren. Van CDA, VVD en D66 gezamenlijk zijn tien raadsleden lid (twee zijn lid van een lokale partij).

Een of twee jaar voor de verkiezingen formeren de meeste politieke partijen een commissie die de opdracht krijgt om zelf kandidaten te werven, gesprekken te voeren met hen en met degenen die door anderen zijn voorgedragen en ze een plaats toe te wijzen op een conceptkandidatenlijst. Nieuwe kandidaten worden op verschillende manieren geworven. Jarenlang hebben selectiecommissies kunnen volstaan met werving van kandidaten binnen de eigen partij door middel van wervingsbrieven aan leden, oproepen in het partijblad en dergelijke. Wie actief was binnen de afdeling kwam eerder in aanmerking voor een plaats op de lijst dan iemand van wie men weinig had gemerkt. Door de afnemende ledenaantallen en de gevoelde noodzaak tot vernieuwing zagen politieke partijen zich gedwongen de politieke gelegenheidsstructuur te verruimen zodat ze 'nieuwe' mensen voor vertegenwoordigende functies konden rekruteren. Daartoe werden kweekvijvers voor de gemeenteraad opgezet, advertenties in een plaatselijke huis-aan-huisblad geplaatst of oproepen op de lokale radio gedaan.

Met name vrouwen en migranten (groepen die ondervertegenwoordigd zijn in politieke instituties) zijn nog eens extra benaderd via specifieke netwerken, aparte oproepen in het afdelingsblad of door hen individueel te werven. Daarbij wordt naar zoveel mogelijk diversiteit gestreefd (zie Leijenaar e.a., 1999). Dit proces wordt begeleid door een discours waarin begrippen als 'vernieuwing', 'de luiken open' en 'nieuw bloed' domineren. Daarmee wordt het beeld gecreëerd van politieke partijen die zijn vastgeroest en daaraan ten onder dreigen te gaan. De situatie is zo urgent dat er zo snel mogelijk een levensreddende operatie op gang dient te worden gebracht. Het 'nieuwe bloed' dat de partijen via het infuus van de vernieuwing wordt toegediend, dient voor revitalisatie te zorgen. De verruiming van de politieke gelegenheidsstructuur moet dat mogelijk maken.

Selectiecommissies gaan daarbij uit van een aantal formele criteria die door de partij of de afdeling zijn vastgesteld (bijvoorbeeld spreiding in leeftijd, deskundigheid, de verhouding tussen mannen en vrouwen, autochtonen en allochtonen, oude en nieuwe raadsleden, geografische spreiding en vertegenwoordiging van woonkernen), de kenmerken van de kandidaten en de indrukken die zij hebben opgedaan tijdens een of meer gesprekken met de aspirant-kandidaten. In deze gesprekken stelt de commissie de kandidaten vragen over hun partijlidmaatschap, motieven om zich verkiesbaar te stellen, de beleidsterreinen waarnaar hun belangstelling uitgaat, hun visie op de ontwikkeling van de gemeente en wat zij denken te bereiken 
tijdens hun raadslidmaatschap enzovoort. Kandidaten van allochtone afkomst mogen rekenen op vragen over hun visie op Nederland als multiculturele samenleving.

Op hun beurt proberen de kandidaten de commissieleden zo goed mogelijk te overtuigen van hun kwaliteiten en de legitimiteit van hun kandidaatstelling. Bij D66 stellen aspirant-raadsleden zichzelf verkiesbaar via een korte CV en een motivering van de redenen waarom zij in de gemeenteraad willen. De aanmeldingen worden verzameld in een 'smoelenboek' dat aan alle plaatselijke leden wordt toegezonden. Het aantal stemmen dat is uitgebracht op een kandidaat bepaalt zijn/haar plaats op de kandidatenlijst. In beide gevallen fungeren deze groepen van personen als poortwachters van de gemeenteraad namens hun partij.

De verruiming van de politieke gelegenheidsstructuur heeft geleid tot een vergroting van en concurrentie tussen beschikbare kandidaten. Vooral blanke mannen, die traditioneel de beste plaatsen op de kandidatenlijst innamen, zagen zich geconfronteerd met vermindering van hun kansen op een hoge klassering. Een raadslid dat aan de voorzitter van zijn afdeling vertelde dat hij zich kandidaat wilde stellen voor de verkiezingen kreeg als reactie: 'Maar jongen, je bent man, jong, wit en afkomstig uit ... [een bepaald gedeelte van de stad Amsterdam]. Van jouw soort hebben we genoeg in de VVD.' Een andere respondent beschreef de concurrentie om het aantal beschikbare plaatsen als volgt:

Het was nog een heel probleem, omdat binnen [de partij in zijn woonplaats] het heel nauw luisterde wie op welke plek op de lijst komt te staan. Dat komt doordat men mensen uit alle groeperingen evenredig vertegenwoordigd wil zien: vrouwen, allochtonen en eventueel gehandicapten. Dus voor een blanke man is er maar één plek op die hele lijst, hoogstens twee. Er wordt ook naar kwaliteit en deskundigheid gekeken. Maar voor een persoon als ik, met mijn achtergrond, waren er wel vier kandidaten voor maar een plek. Dus ik moest opboksen tegen die andere blanke jongens van tussen de veertig en vijftig. Er waren er een stuk of vier/vijf voor negen zetels, vier vrouwen, twee jongeren, allochtonen, man en vrouw. En de zittende fractie. Want, als je het niet verschrikkelijk slecht gedaan hebt, dan blijf je.

Het laatste woord bij partijen die gebruikmaken van een selectiecommissie is aan de algemene ledenvergadering. Die stelt de definitieve lijst vast. Kandidaten die laag zijn geplaatst of die de kans lopen te worden verdrongen van hun verkiesbare plek door een andere kandidaat, proberen daar zaken te doen. De (autochtone) heer B. zag tijdens de stemming over de definitieve lijst zijn plek bedreigd door een allochtone kandidaat die al drie keer een plaats was gezakt. Hij greep onmiddellijk in:

(...) toen kwam mijn plek aan de beurt en ik dacht dan gaat de vergadering voor de derde keer misschien voor X kiezen, en lig ik eruit. Dus ben ik nadat hij verloor naar hem toegegaan en heb gezegd: 'X, alles goed en wel maar de achtste 
plaats is voor mij en daar blijf je van af. Maar ik zal je helpen, want ik steun je op negen, en dan zet ik mijn mensen in voor jouw negende plek'. Er was wel een andere kandidaat die uit the blind kwam, maar die haalde het van geen kanten. Dus kwam ik op de achtste en op de negende kwam er ook iemand uit de zaal. Maar mijn groep heeft toen gezegd, nu moet $\mathrm{X}$ het worden.

Vanuit het perspectief van zijn allochtone 'concurrent' die door de selectiecommissie op de twaalfde plek was geplaatst, klinkt het verhaal over de stemming als volgt:

Toen hebben wij alles ingezet om mij binnen de negen te krijgen. Wij hadden verwacht dat wij een of twee zetels zouden winnen. Dus naar tien of elf zouden gaan, ik nam genoegen met een negende plaats. We hadden ervoor gezorgd dat bij de vergaderingen... [leden van zijn etnische groep] partijleden ook aanwezig waren. Ik bedoel: er zijn veel leden en die hebben wij toen aangesproken. Ik heb niemand extra lid gemaakt. Het is natuurlijk wel een feit dat in '98 en daarvoor het moeilijk ging met de partij. De animo om een partijvergadering bij te wonen was niet groot. In 1990 waren er misschien 110 mensen of zo aanwezig, van wie de helft Nederlanders en de andere helft... [leden van zijn etnische groep]. Nou, toen hebben wij ingezet vanaf plaats zes en uiteindelijk de negende plek bemachtigd via stemmingen. Dat hebben wij dus wel binnen kunnen halen.

De heer B. is bij de verkiezingen van maart 2002 in de raad gekozen. Maar het is herhaaldelijk voorgekomen dat kandidaten die op een 'veilige' plek dachten te staan alsnog zijn verdrongen door kandidaten van allochtone afkomst op onverkiesbare plaatsen die via voorkeurstemmen in de raad zijn gekozen. Het aantal voorkeurstemmen is in sommige gevallen zo groot dat kandidaten van allochtone afkomst meer dan een raadszetel binnenhalen voor hun partij. Zo werd Rob Oudkerk, die sprak over 'kut-Marokkanen', er fijntjes aan herinnerd dat dankzij de voorkeursstemmen van die kut-Marokkanen de PvdA bij de gemeenteraadsverkiezingen in 2002 twee zetels extra heeft gewonnen in Amsterdam. Bij de verkiezingen van maart 2002 werden in Rotterdam zes politici van allochtone afkomst, die zo laag waren geplaatst dat hun (her)verkiezing niet zeker was, door voorkeurstemmen in de gemeenteraad gekozen. Ook in Den Haag was dat het geval. In de Volkskrant onthulde mevrouw Admiraal, scout van de PvdA, de strategie van haar partij met betrekking tot kandidaten afkomstig uit de etnische minderheden:

Sommige kandidaten staan puur uit opportunisme op de lijst, vanwege hun etnische achtergrond en niet om hun kwaliteiten. Ze moesten na vier jaar politieke rijping instromen. (de Volkskrant, 8 maart 2002) 


\section{Poortwachters en aspirant-kandidaten}

Drie tot vier maanden voor de gemeenteraadsverkiezingen van 1994 werd de heer A. in een boekhandel in zijn woonplaats door een actief lid van Groen Links gevraagd of hij niet op de kandidatenlijst wilde. Na een gesprek met een zittend raadslid heeft de heer A. zich aangemeld en een sollicitatiegesprek gevoerd met de selectiecommissie. De heer B., die raadslid, lid van de Provinciale Staten, secretaris van zijn partij en Tweede-Kamerlid was, is op een soortgelijke manier geworven. Toen een prominent lid van zijn partij hoorde dat hij de Kamer ging verlaten, werd hij gebeld met het verzoek of hij zich wilde kandideren.

Volgens raadsleden die zelf deel hebben uitgemaakt van selectiecommissies gaat dat wel vaker zo. Met de verkiezingen in aantocht kijken actieve leden van politieke partijen in hun omgeving rond of er nog geschikte kandidaten zijn. De eerste voorkeur van de rekruteerders gaat uit naar leden die reeds actief zijn binnen de partij (zowel op lokaal als landelijk niveau) of lid zijn geweest van een deel(gemeente)raad. In de hoop dat het politiek kapitaal dat al doende is opgebouwd zich zal uitbetalen tijdens het raadslidmaatschap. De eerdergenoemde heer B. was voor hij werd geworven op landelijk niveau actief geweest. Maar de meeste kandidaten waren al jarenlang actief geweest binnen hun afdeling toen zij werden gerekruteerd of zichzelf beschikbaar stelden. Sommigen waren gewoon aan de beurt. Ze hadden de lange mars door de partij voltooid en werden op grond van hun verdiensten gevraagd. Anderen (met name van PvdA-huize) kwamen dankzij het vernieuwingsproces eerder aan de beurt. Mevrouw C. is een van die kandidaten. Ze was voorzitter van haar afdeling toen ze samen met twee andere jonge personen werd voordragen door enkele prominenten (voormalige wethouders) van haar afdeling. Het was de tijd van de 'grote schoonmaak' waarin de Amsterdamse PvdA de raadsfractie probeerde te vernieuwen. Tijdens de algemene vergadering voerden de prominenten actie om haar en andere jongeren vijf plaatsen hoger te krijgen onder het motto 'geef de jeugd de vijf'. Om een andere kandidate hoger op de lijst te krijgen, hield een van haar medestanders de algemene vergadering voor dat als de partij streefde naar 'vernieuwing en jong bloed' ze dat ook moest waarmaken.

De heer D. (PvdA-lid) werd ook gerekruteerd in het kader van het vernieuwingsproces. Na de forse nederlaag bij de verkiezingen van 1986 besloot de partij verder te kijken dan het Amsterdamse partijkader, en op zoek te gaan naar personen die maatschappelijk actief waren. Bovendien wilde ze de diversiteit van de stad Amsterdam in de fractie laten uitkomen. De heer D. die als bestuurslid zelf aan het vernieuwingsproces heeft bijgedragen, kon moeilijk weigeren toen hij in 1993 door verschillende personen werd gestimuleerd om zich kandidaat te stellen in het kader van de vernieuwing van de partij.

Mevrouw M. is ook in het kader van de vernieuwing aangezocht. Ze was al enkele jaren lid van een politieke partij toen zij door de afdelingsvoorzitter werd gevraagd om zich kandidaat te stellen. Ze voldeed aan alle kenmerken die werden geassocieerd met de vernieuwing: 
Ik was jong, ik was vrouw, ik was allochtoon en ik kan goed formuleren. Ik denk dat ze mij daarom hebben gevraagd.

Maar ook personen die niet actief zijn binnen hun partij worden gerekruteerd. Neem bijvoorbeeld mevrouw Y. Toen zij door een wethouder van haar partij werd gevraagd of zij wilde meedoen aan de verkiezingen van 1994 was zij nog nooit actief geweest binnen Groen Links. Ze haalde wel de kandidatenlijst, maar niet de gemeenteraad. Op de vraag waarom zij is gevraagd, zegt mevrouw Y.:

Ik denk vanwege het feit dat ik een aardig netwerk heb binnen de stad en omdat iedereen vond dat er wel wat vernieuwing nodig was. Omdat ik een bepaalde inbreng kon hebben die nuttig zou zijn. Ik ben twaalf jaar opbouwwerker geweest in [...]. Daar ken ik allerlei mensen. En misschien ook omdat ik vrouw ben.

Tijdens het 'sollicitatiegesprek' met deze kandidaten noemde de kandidaatstellingscommissie het netwerk dat zij als opbouwwerker had opgebouwd een belangrijke reden om haar te rekruteren. De partij hoopte via haar voeling te kunnen houden met wat er zoal leeft bij de lokale bevolking. Vier jaar later werd mevrouw Y. wel gekozen, evenals haar partijgenote mevrouw $\mathrm{W}$. die op het moment van rekrutering geen partijlid was. De werving van deze twee vrouwen is een voorbeeld van de manier waarop politieke partijen in het kader van het proces van vernieuwing ook kandidaten van buiten proberen te interesseren voor de politiek. Mevrouw W. werd geworven door een gemeenteraadslid dat op dat moment volkshuisvesting in zijn portefeuille had. De belangrijkste reden hiervoor was de deskundigheid die zij op dit gebied had opgebouwd als directeur van een woningstichting. Haar sekse maakte haar des te aantrekkelijker voor de partij. Mevrouw K., die als lid van de selectiecommissie medeverantwoordelijk is geweest voor hun plaats op de conceptlijst, legt uit waarom dat is:

Je vraagt je af: wie is interessant. En dan maak je een long list en dan ga je eens kijken wie er allemaal op staan. Op basis van allerlei criteria kijk je of er iemand is die iets met milieu heeft, of iets met sociaal werk. Je neemt een aantal onderwerpen, maar dan neem je ook jong-oud, man-vrouw, allochtoon-autochtoon.

Nevin Özütok is sinds 1998 raadslid voor Groen Links in Amsterdam. Voor de gemeenteraadsverkiezingen van maart 2002 is zij door de kandidatencommissie van haar partij op nummer twee geplaatst. Daarmee werd zij door haar partij kandidaat gesteld voor het wethouderschap. Volgens voorzitter Tanja van deze commissie is zij vooral vanwege haar rijke ervaring gekozen. Tegenover het weekblad Contrast erkent Tanja dat Özütoks Turkse afkomst bij die keuze een rol heeft gespeeld: 
De commissie heeft de opdracht gekregen een zo divers mogelijke kandidatenlijst samen te stellen. Als Turkse én als vrouw past Özütok in dat plaatje. Maar haar kwaliteiten staan voorop.

Hoezeer de kwaliteiten van Özütok vooropstaan, het feit dat zij van Turkse afkomst en vrouw is maakt haar net wat interessanter voor haar partij. Haar etnische afkomst en haar sekse vormen als het ware het politiek kapitaal van mevrouw Özütok en haar partij. Dat was ook het geval bij de politieke partij die mevrouw E. vroeg om te solliciteren, hoewel zij geen partijlid was. Deze partij had daarvoor drie redenen: haar sekse, haar netwerk binnen de Turkse bevolkingsgroep en haar betrokkenheid bij acties tegen terugdringing van migranten. Zo is zij één van de oprichtsters van een Turkse vrouwenvereniging en van een landelijk centrum voor buitenlandse vrouwen en bestuurslid van een migrantenvrouwenhuis. Ze noemt zichzelf een sleutelfiguur die weet wat er leeft binnen de Turkse bevolkingsgroep. Enkele jaren voor haar installatie als gemeenteraadslid had het CDA haar ook al op de kandidatenlijst willen plaatsen. Ze heeft geweigerd omdat zij zich niet kon identificeren met het christen-democratische gedachtegoed van deze partij. Welke van de persoonlijke en sociale kenmerken de doorslag heeft gegeven bij de twee partijen die haar rekruteerden is haar niet duidelijk. Ze hecht daar ook niet zo aan. Dat geldt voor wel meer personen die worden aangezocht met het verzoek zich kandidaat te stellen. Zij gaan ervan uit dat zij in de eerste plaats om hun deskundigheid en netwerken zijn gevraagd, maar weten ook dat geen enkele politieke partij 'vrij is van enig opportunisme' (in de woorden van een Amsterdams raadslid) Het biedt hun wel de kans om optimaal gebruik te maken van de verruiming van de gelegenheidsstructuur. Zo hield mevrouw K. de selectiecommissie voor dat zij alle begrip had voor het feit dat zittende raadsleden hoog op de lijst worden geplaatst. Maar voor haar 'marktpositie' zou het slecht zijn als ze op een onverkiesbare plaats terechtkwam:

Ik wilde absoluut een plek die recht deed aan mijn marktpositie op dat moment, ik wilde absoluut niet op een onverkiesbare plaats, ik ben daar ook principieel tegen, omdat ik niet van plan ben om voorkeurstemmen te werven. Ik peins er niet over. Dat zal ook mijn politieke carrière bepalen. Als ik niet goed op een lijst sta, dan trek ik mij terug.

De eerdergenoemde heer D. ging nog veel verder. Hij eiste zowel een direct verkiesbare plaats (hij wilde niet onderaan de lijst omdat hij geen zin had om alleen als stemmentrekker te fungeren) als meer allochtonen op de lijst. Zijn eerste eis werd ingewilligd doordat hij op de vierde plek werd geplaatst. De inwilliging van zijn tweede eis was niet al te moeilijk: hij was namelijk de derde allochtone kandidaat op de lijst.

Maar zelfs als kandidaten vermoeden dat hun etnische afkomst of sekse de belangrijkste reden is geweest om hen te rekruteren, dan blijken ze het nog veel 
belangrijker te vinden dat zij in de gemeenteraad een aantal sociale en politieke doelen kunnen verwezenlijken. De vraag of zij als stemmentrekker en/of token-allochtoon zijn binnengehaald past hierin niet.

\section{Overeenkomsten en verschillen}

Verschillen deze raadsleden van allochtone afkomst sterk van hun autochtone collega's in de periode 1980-1998? Bij de volgende vergelijkingen moet steeds worden bedacht dat het om een klein aantal allochtone raadsleden gaat maar zij vormen wel de gehele populatie. De verhoudingen tussen mannen en vrouwen is nauwelijks verschillend bij autochtone en allochtone gemeenteraadsleden: respectievelijk 65 procent mannen bij de autochtonen en 71 procent bij de allochtonen. Of anders geformuleerd: van de mannelijke raadsleden heeft elf procent een allochtone achtergrond, terwijl bij de vrouwen negen procent zo'n achtergrond heeft. Ook in leeftijd bij hun aantreden in de raad verschillen autochtone en allochtone raadsleden weinig, de gemiddelde leeftijd was respectievelijk 40 en 37. Bij de leeftijdsgroep tussen de 33 en 37 hebben allochtonen een hoger percentage, bij de leeftijdsgroep boven de 46 is dat net omgekeerd.

Uit eerder onderzoek (Berger e.a., 2001, ze hebben niet dezelfde gemeenteraden onderzocht) is gebleken dat allochtone raadsleden over het algemeen redelijk hoog zijn opgeleid en dat wordt in ons onderzoek bevestigd. Niettemin levert tabel 1 een opmerkelijk resultaat op in het licht van de voortdurende en zorgelijke discussies over de onderwijsachterstand bij allochtonen (vgl. Meijnen \& Rupp, 200o).

De verschillen tussen het onderwijsniveau van de allochtonen en autochtone raadsleden zijn zeer gering, zoals blijkt uit tabel 1. 76 procent van alle raadsleden heeft een hbo- of universitair onderwijsniveau. Hieruit valt te concluderen dat de gemeenteraden in de vier grote steden wat betreft onderwijsniveau erg homogeen zijn en allochtone raadsleden maken daarop geen uitzondering. Het argument dat de opname van allochtone gemeenteraadsleden een democratische noodzakelijkheid was omdat anders grote groepen migranten in de grote steden zouden worden uitgesloten van vertegenwoordiging van het lokale bestuur, lijkt ons terecht. Maar de vraag kan worden gesteld hoe representatief deze raadsleden zijn voor de Turkse en Marokkaanse gemeenschappen, gezien hun hoge onderwijsniveau. Natuurlijk kan diezelfde vraag ook gesteld worden over de Nederlandse gemeenteraadsleden. Zo'n verschil tussen achterban en vertegenwoordiger bestond ook voor de Tweede Wereldoorlog al, zoals we hierboven hebben laten zien. De tabel laat bovendien zien dat alle gemeenteraadsleden zijn gerekruteerd uit een min of meer homogene groep kandidaten als het op hun onderwijsniveau aankomt. Deze homogeniteit wordt nog duidelijker als het onderwijsniveau van hun vaders bij de analyse wordt betrokken. 
Tabel 1: Onderwijsniveau naar etniciteit (in percentages)

\begin{tabular}{lrrr} 
& $\begin{array}{r}\text { Allochtoon } \\
(\mathbf{n}=\mathbf{4 3})\end{array}$ & $\begin{array}{r}\text { Achtergrond } \\
\text { Nederlands } \\
(\mathbf{n}=\mathbf{3 4 3})\end{array}$ & Totaal \\
\hline Onderwijsniveau & 5 & 3 & 3 \\
Primair & 19 & 21 & 21 \\
Secundair & 76 & 76 & 76 \\
Tertiair & 100 & 100 & 100 \\
\hline Totaal & 10 & &
\end{tabular}

Tabel 2: Relatie tussen onderwijsniveau vader en raadslid opgesplitst naar etniciteit (in percentages)

\begin{tabular}{|c|c|c|c|c|c|c|}
\hline & \multicolumn{6}{|c|}{ Etniciteit } \\
\hline & \multicolumn{4}{|c|}{$\begin{array}{l}\text { Allochtoon } \\
\qquad(n=36)\end{array}$} & \multicolumn{2}{|c|}{$\begin{array}{l}\text { Autochtoon } \\
(n=304)\end{array}$} \\
\hline & \multicolumn{6}{|c|}{ Onderwijsniveau van vader raadslid } \\
\hline & $\mathbf{I}$ & II & III & $\mathbf{I}$ & II & III \\
\hline \multicolumn{7}{|c|}{$\begin{array}{l}\text { Onderwijsniveau } \\
\text { raadslid }\end{array}$} \\
\hline I & 6 & 一 & - & 6 & 3 & - \\
\hline II & 22 & 21 & - & 22 & 19 & 11 \\
\hline III & 72 & 79 & 100 & 72 & 78 & 89 \\
\hline Totaal \% & 100 & 100 & 100 & 100 & 100 & 100 \\
\hline $\mathrm{N}$ & 18 & 14 & 4 & 101 & 110 & 93 \\
\hline
\end{tabular}

Legenda: I = primair, II = secundair, III = tertiair

Tabel 2 geeft aan dat er onder de allochtone raadsleden een tamelijk grote onderwijsmobiliteit van vaders op zonen is. Dat is niet onverwacht, maar wel opmerkelijk is dat ook betrekkelijk veel vaders al redelijk hoogopgeleid zijn (veertien hebben secondair onderwijs genoten en vier zelfs tertiair). Het komt erop neer dat de helft 
van de allochtone gemeenteraadsleden afkomstig is uit een milieu waar op zijn minst de vader redelijk hoog is opgeleid. Deze onderwijsmobiliteit is bij de autochtone raadsleden iets minder, maar niet zo heel erg veel. De raadsleden met een Surinaamse achtergrond nemen een middenpositie in omdat hun niveau hoger ligt dan dat van de Marokkaanse en Turkse raadsleden, maar lager dan dat van de Nederlandse.

Het is ook mogelijk te kijken naar de 'politieke omgeving' van de raadsleden. Er is gevraagd wie in de familie politieke functies heeft vervuld. De antwoorden leveren een breed scala van antwoorden over heel diverse functies en uiteenlopende familieleden. We hebben alle antwoorden teruggebracht tot een simpel ja-nee-antwoord. Dat levert een vrijwel gelijk percentage ja-antwoorden voor allochtone en autochtone raadsleden op dat rond de dertig procent ligt. Twee allochtone groepen springen er enigszins uit: Surinamers en Turken met respectievelijk 33 en 38 procent familieleden die ooit een politieke functie hebben vervuld.

Gemeenteraadsleden vertegenwoordigen netwerken van contacten met allerlei organisaties. Dat geldt zowel voor autochtone als allochtone raadsleden, maar de autochtone raadsleden hebben bindingen met grotere organisaties, zoals culturele, ziekenhuis- en onderwijsorganisaties, die dikwijls nog verzuild zijn. Bij allochtone raadsleden zijn het bindingen met andere, zo men wil, zwakkere organisaties, zoals hulpverlenings-, migranten- of bemiddelingsorganisaties. Dit verschil in structuur van de respectievelijke netwerken is wel het meest opvallende onderscheid tussen de twee groepen. Het duidt erop dat allochtone raadsleden nog beperkt in de brede samenleving waren verankerd. Een positie die enigszins vergelijkbaar is met vrouwelijke raadsleden in de jaren twintig en dertig van de vorige eeuw.

\section{Motieven van kandidaten}

Vraag politici waarom zij zich kandidaat hebben gesteld voor de verkiezingen en ze putten zich uit in begrippen, die hun specifieke betekenis onder andere ontlenen aan het discours van de partij waarvan zij lid zijn en aan hun eigen invulling. Hun motieven variëren van algemeenheden, zoals 'streven naar rechtvaardigheid', 'opkomen voor de sociaal zwakkeren', 'bevordering van de eigen verantwoordelijkheid van mensen', 'solidariteit', 'participatie van allen', 'emancipatie van burgers', 'leefbaarheid' en 'sociale cohesie' tot persoonlijke motieven als 'verbondenheid met de stad', 'inzetten van mijn bestuurlijke ervaring voor de stad', 'beïnvloeden van de eigen omgeving', 'niet aan de zijlijn willen staan' en 'besluiten nemen over dingen die mij raken'. Hierin is geen verschil tussen raadsleden van allochtone en autochtone afkomst.

De meeste raadsleden van allochtone afkomst noemen naast bovengenoemde motieven ook nog motieven die zijn gerelateerd aan de ontwikkeling van Nederland tot een multi-etnische en multiculturele samenleving. Hoewel zij benadrukken dat zij er voor alle burgers zijn, vormt de kans die wordt geboden om het allochtone deel van de bevolking in het officiële politieke domein te vertegenwoordigen een 
belangrijke drijfveer. Zelfs raadsleden van allochtone afkomst die zich onder geen enkel beding op deze afkomst wensen te beroepen (en ook niet door anderen als zodanig willen worden aangesproken) moeten erkennen dat door hun aanwezigheid de etnische groep waartoe zij behoren zich vertegenwoordigd weet in de gemeenteraad.

Raadsleden van autochtone afkomst die gevraagd werden naar de betekenis van allochtonen in de gemeentelijke politiek komen met dezelfde soort argumenten als hun allochtone collega's. Een raadslid sprak van een 'opdracht van deze tijd'. Volgens beide groepen is de aanwezigheid van allochtonen in de politiek belangrijk, omdat daarmee:

- recht wordt gedaan aan de diversiteit van de Nederlandse samenleving:

'Ja, men leeft in Den Haag en men ziet dat dat de werkelijkheid verandert. Wil je jezelf niet buiten de werkelijkheid plaatsen dan moet je je open stellen voor die nieuwe ontwikkelingen.'

- een bevolkingscategorie wordt vertegenwoordigd die nog niet voldoende is doorgedrongen tot het politieke domein:

'Je bent volksvertegenwoordiger, 66\% van de schoolgaande jeugd bestaat uit allochtonen, dan ben ik er trots op dat ik voor die allochtonen ben gevraagd.'

- personen in de gemeenteraad komen die vanwege hun afkomst een intermediaire rol kunnen vervullen tussen de politiek en de allochtone bevolkingsgroepen: 'En ik was natuurlijk vanwege mijn afkomst een geschikte tussenpool, zou je kunnen zeggen. Omdat ik verschillende werelden kan overbruggen.'

- raadsleden komen die vanwege hun etnische afkomst meer kennis en inzicht hebben in wat er in de allochtone bevolkingsgroepen leeft:

'We willen allochtonen ook graag in de fractie hebben omdat ze hopelijk meer inzicht hebben in wat de behoeften van allochtonen zijn dan wij witten hebben.'

- leden van hun etnische groep of allochtonen in het algemeen zich via hen veel meer gaan identificeren met de politiek en het bestuur in Nederland:

'Maakt niet uit waar je vandaan komt. Het is alleen maar belangrijk om de burger het gevoel te geven dat hij zich kan herkennen in het bestuur, maar voor de rest maakt het niet uit.'

Raadsleden van allochtone afkomst zien zichzelf als vertegenwoordigers van hun etnische groep en/of van het allochtone deel van de bevolking. Zij maken zichzelf en worden door anderen gemaakt tot woordvoerders van hun etnische groep. Dat geldt ook voor raadsleden die weigeren zichzelf als vertegenwoordiger van hun etnische groep te beschouwen, en ook niet als zodanig willen worden aangemerkt.

Het raadslidmaatschap van allochtonen wordt gerechtvaardigd door wat Pitkin (1967) descriptive representation heeft genoemd. Het gaat om politieke representatie die gebaseerd is op een essentialistische notie dat een gedeelde etnische afkomst en ervaringen voldoende zijn om een bepaalde groep te vertegenwoordigen in het politieke domein. Belangrijk is om wat de kandidaten zijn (of horen te zijn volgens anderen) en niet om wat zij doen. Zij staan voor hun etnische groep of (in het alge- 
meen) voor de groep der allochtonen op grond van een geconstrueerde gelijkenis of relatie met hen. De identiteit van vertegenwoordiger en vertegenwoordigden vallen samen. Daarbij wordt voorbijgegaan aan bijvoorbeeld machtsverschillen tussen de vertegenwoordigers en de vertegenwoordigden.

Inherent aan descriptive representation is de opvatting dat de gemeenteraad een spiegel dient te zijn van de bevolking. Zo was de belangrijkste reden van heer Z. (een niet-Nederlander die met de verkiezingen van 1986 in aantocht werd gevraagd of hij lid wilde worden van de PvdA) het uitgangspunt dat de raad een afspiegeling moest zijn van de Rotterdamse bevolking. Nauw verwant hieraan is het argument dat door een Amsterdams raadslid van het CDA naar voren werd gebracht. Naar zijn mening is politiek gebaseerd op vertegenwoordiging van verschillende groepen uit de samenleving. Een partij kan niet aan bepaalde (allochtone) bevolkingsgroepen vragen om op haar kandidaten te stemmen en tegelijkertijd de leden van die groepen uitsluiten van vertegenwoordigende functies namens de partij. Beiden willen ze recht doen aan de veranderde samenstelling van de bevolking, ondanks het vermoeden dat hun etnische afkomst een belangrijke reden is geweest om hen te rekruteren.

Voor de eerdergenoemde heer B. betekent de werving van allochtonen de eerste stap in een veranderingsproces. Hij vindt zelfs rekrutering op grond van de gedachte 'we hebben een allochtoon nodig' niet erg. Wel als het daarbij zou blijven. Als lid van het stedelijk bestuur van zijn partij is hij mede verantwoordelijk geweest voor het vernieuwingsproces binnen zijn partij. De partij heeft besloten om verder te kijken dan het Amsterdamse partijkader en op zoek te gaan naar personen die maatschappelijk actief zijn om zo de diversiteit van de stad in de fractie te doen uitkomen. Daarvoor heeft de partij mensen uit verschillende circuits nodig. Omdat het niet vanzelfsprekend is dat allochtonen zich uit zichzelf aanmelden, wil hij de werving niet aan een natuurlijk proces overlaten. Er gebeurt dan niets. De enige groep die daarvan profiteert is 'die der witte mannen'.

Mevrouw W. (raadslid van autochtone afkomst) geeft onomwonden toe dat allochtonen onder andere kandidaat worden gesteld in de hoop dat zij zich ontpoppen tot geheide stemmentrekkers. Mevrouw F. heeft daar geen moeite mee. Niet alleen de partij heeft hier voordeel van. Zij liet zich kandideren om:

dingen voor migranten gedaan te krijgen. Je kunt excuus-truus als iets negatiefs zien, moet ook, maar je kunt ook doelbewust in een partij excuus-truus zijn, mits je de dingen die je wilt bereiken doorzet. En zo heb ik het ook gebruikt.

Maar, om zich te ontpoppen tot stemmentrekker moeten kandidaten de kiezers zodanig aanspreken dat deze zich met hen gaan identificeren. De gelijkenis waarop het proces van descriptive representation is gebaseerd, is namelijk niet vooraf gegeven. Ze moet worden gecreëerd door middel van representatie (in de betekenis van een bepaalde weergave van de werkelijkheid). Representatie is geen simpele reflectie van de werkelijkheid, maar schept de werkelijkheid. Zelfs wanneer ze betrekking 
heeft op de vertegenwoordiging van burgers uit bepaalde etnische groepen door vertegenwoordigers uit dezelfde etnische groepen. De kandidaten moeten stemgerechtigde allochtonen ertoe 'verleiden' om hun, als lid van dezelfde etnische groep, volmacht te geven om namens hen op te treden in de gemeenteraad.

Dit proces van imaginaire identificatie (Zizek, 1989) wordt in gang gezet door middel van folders die bij toko's, kruideniers en slagers worden achtergelaten of via moskeebezoek (in een aantal gevallen samen met aansprekende figuren uit de politieke partij waarvoor zij kandidaat staan). Met het argument dat deze manier van campagne voeren beter aansluit bij de belevingswereld van hun landgenoten. Ze kunnen echter rekenen op afkeurende geluiden uit hun partij, omdat zulks in Nederland niet gebruikelijk zou zijn. Meerdere respondenten klaagden over de ruzies met afdelingsbesturen die niet gediend zijn van deze (particularistische) wijze van campagne voeren. Men spreekt al gauw van ronselen van stemmen (terwijl het bij kandidaten van autochtone afkomst als netwerken wordt beschouwd), eenzijdige belangenbehartiging en zelfs van cliëntelisme. Volgens een lokale partijfunctionaris

[doet] de politieke cultuur in die landen (waar raadsleden van allochtone afkomst vandaan komen) wat meer aan cliëntelisme, de ene dienst is de andere waard. Wij zijn in Nederland toch wat calvinistischer. Als samenleving, vertroetelen we elkaar niet zo gauw omdat je daar of daar lid van bent. ${ }^{2}$

Dit stigma blijft politici van allochtone afkomst achtervolgen. Hoezeer ze ook benadrukken dat zij in de eerste plaats voor alle burgers willen opkomen en slechts in sommige gevallen voor een bepaalde etnische groep.

\section{Ervaringen en uitstroom}

\section{Dilemma's en ambivalenties}

'We zijn er voor alle burgers. Iedereen heeft natuurlijk zijn eigen netwerk. Maar als hij echt onder druk gezet zou worden op een verkeerde manier, dan weet hij dat hij mij dat moet laten weten.' Deze woorden zijn afkomstig van de Rotterdamse CDAfractievoorzitter Bolsius (Petronelli, 200o) die zo zijn zorgen had over zijn fractiegenoot Erdal (van Turkse afkomst).

Ze zijn tekenend voor het wantrouwen ten opzichte van raadsleden van allochtone afkomst bij wie een particularistische instelling wordt vermoed. Ze zouden alleen voor de eigen groep opkomen en zich minder druk maken om het belang van alle burgers van de stad. Gevraagd en ongevraagd krijgen zij het soort advies dat wij optekenden uit de mond van een van de fractievoorzitters in de Haagse gemeenteraad: 
Als raadslid ben je raadslid voor heel Den Haag, voor allerlei problemen. Je kunt niet zeggen ik ben vier jaar raadslid voor de problemen die zich in mijn naaste omgeving/voorkeursgroep voordoen.

Een raadslid uit een andere stad reageert op dit soort uitspraken dat zo'n instelling niet altijd van haar mag worden verwacht. Zij zegt dondersgoed te weten dat ze onder andere is binnengehaald om allochtone stemmen te trekken. Zij heeft de selectiecommissie evenwel duidelijk gemaakt dat ze geen zin heeft in alleen maar window dressing. Als de politiek haar binnenhaalt omdat ze een grote nieuwe groep van kiezers wil bereiken - en daar heeft zij geen enkel bezwaar tegen omdat zulks de herkenbaarheid van de politiek vergroot - meent zij het recht te hebben om ook in het belang van die groep te kunnen optreden. Sommige raadsleden voelen dat als een verplichting tegenover degenen die hen kozen. Neem bijvoorbeeld de heer P. die in 1998 een persoonlijke campagne voerde (met steun van zijn partij) en 3650 voorkeurstemmen kreeg:

Ik had mijn eigen zetel verdiend. Dat heeft impact op je functioneren. Het was een signaal dat je afgeeft naar de partij, de raad en de gemeenschap. Het geeft aan dat je een achterban hebt, dat mensen vertrouwen in je hebben, en dat je bekendheid hebt. Aan de andere kant maakt het je positie extra moeilijk. Hoe meer voorkeurstemmen, hoe meer verwachtingen, niet alleen van de mensen die je hebben gekozen maar ook van de partij en fractie.

In tegenstelling tot de politieke partij lijken degenen die stemden op kandidaten van allochtone afkomst te verwachten dat zij niet alleen namens hen optreden, maar dat ook in hun belang doen. Representing as 'acting for', zoals Pitkin (1967) dat noemt. Maar in de heterogene Nederlandse samenleving wenst men geen rekening te houden met belangen van specifieke etnische groepen. Deze belangen worden ondergeschikt gemaakt aan de algemene zaak, aan de belangen van alle burgers. En daarmee komen deze raadsleden klem te zitten tussen het wantrouwen van hun politieke partijen en de verwachtingen van hun kiezers die zij soms zelf hebben opgeroepen door hun manier van campagne voeren (vgl. de dagboeken van de verschillende 'allochtone politici' in Petronilla, 2000).

Het wantrouwen van de politieke partijen komt onder meer voort uit het idee dat raadsleden van allochtone afkomst de uitgangspunten van het moderne Nederlandse politieke bestel zouden overtreden. In Nederland hoort politiek te worden bedreven zonder last of ruggespraak. De Nederlandse politicus, opgegroeid in Nederland, is een modern individu, vrij van bindingen met specifieke groepen, dat zich slechts met algemene politieke projecten identificeert. Raadsleden van allochtone afkomst daarentegen zouden nog niet door het water van de moderniteit zijn gewassen. Nog niet onafhankelijk genoeg, te veel gebonden zijn aan het collectief. Ze zouden niet het algemeen belang dienen maar slechts het particuliere belang van de eigen etnische groep en zich schuldig maken aan cliëntelisme. Wie de moed 
heeft om te pleiten voor een beleidsmaatregel ten gunste van de categorie der allochtonen stuit dan ook op irritatie en wantrouwen:

Maar je merkte het wel op die momenten waarop ik dus sterk de nadruk op een allochtoon belang zou willen leggen. Dat men je dat niet in dank afnam onder het mom van dat je voor het algemeen belang moet gaan.

Veel raadsleden van allochtone afkomst ervaren deze houding als kwetsend. Ze beschouwen dit als het zoveelste bewijs dat Nederlandse politieke partijen alleen maar alibi-Ali's willen, die slechts op hun voorwaarden mogen meedoen in het politieke domein. Ze worden binnengehaald als vertegenwoordiger van een bepaalde etnische groep en als stemmentrekker. Als zij, dankzij de stemmen van de leden van hun etnische groep, in de raad zijn gekozen, moet het daarmee afgelopen zijn. Daarnaast hebben zij het idee dat er met twee maten wordt gemeten. Er zijn maar weinig mensen die de VVD-Amsterdam van cliëntelisme zullen beschuldigen wanneer deze een diner organiseert waaraan tegen betaling van een fors bedrag kan worden aangezeten, zoals in de aanloop naar de gemeenteraadsverkiezingen van maart 2002 gebeurde. Terwijl het voorstel van een Haags raadslid voor een Indiatown (naar analogie van de zeer succesvolle Chinatowns) met wantrouwen wordt bejegend omdat het de Hindoestaans-Surinaamse bevolkingsgroep zou bevoordelen. Waar de meeste grote Europese en Noord-Amerikaanse steden graag een Chinatown binnen hun poorten willen als toeristische trekpleister wordt in Den Haag een Indiatown afgewezen, terwijl de initiatiefnemers zo'n wijk als teken zien van de snelle en succesvolle integratie en emancipatie in Nederland van Hindoestanen en Surinamers. Volgens de meeste respondenten van allochtone afkomst kunnen raadsleden van autochtone afkomst die opkomen voor bepaalde organisaties (toneelgezelschappen, voetbalclubs) of politieke projecten, naar hun mening op veel minder wantrouwen rekenen en zullen zij niet snel van dubbele loyaliteit worden beschuldigd:

Als een financiële man zich bezighoudt met financiën en bedrijven in Amsterdam, dan heeft hij toch ook dubbele loyaliteiten? Of als een milieuman zich alleen bezighoudt met milieuorganisaties is dat toch ook dubbele loyaliteit? Waarom vinden we het opeens eng als het een etnische kleur heeft of een etnische factor meespeelt. Ik heb nooit een goed argument gehoord waarom mensen vinden dat dat aspecten zijn van dubbele loyaliteit.

Daarnaast zijn er de hooggespannen verwachtingen van leden van de etnische groep waarvan zij deel uitmaken. Deze komen voort uit een bepaalde opvatting over etnische identiteit, namelijk dat leden van etnische groepen zich op natuurlijke wijze met elkaar en de groep identificeren. Het is een opvatting waarop raadsleden van allochtone afkomst zich hebben gebaseerd bij de constructie van de gelijkenis. Raadsleden van autochtone afkomst delen dit wereldbeeld. Vandaar het wantrouwen vooraf en het gebruik van termen als cliëntelisme (waarmee overigens niet is 
gezegd dat sommige raadsleden zich nooit schuldig zouden maken aan cliëntelisme.

De houding van raadsleden van allochtone afkomst laat echter zien dat identificatieprocessen zich op een andere manier voltrekken dan zij, hun collega's van autochtone afkomst en de leden van hun etnische groep, in sommige gevallen denken. Identiteiten of belangen zijn namelijk niet vooraf gegeven. Ze zijn de uitkomst van identificatieprocessen waarin mensen worden 'aangesproken' tot een bepaalde identiteit. Dat geldt evenzeer voor politici. Hun (politieke) identiteit ontstaat mede uit de wijze waarop zij zich identificeren met bepaalde politieke projecten en met de vertogen waarin deze projecten vorm krijgen. Identificatie met hun etnische groep is slechts een van de vele identificaties waaraan zij soms gehoor (willen) geven. Deze identificatie is bovendien partieel en tijdelijk. Zoals elk subject worden ook zij 'aangesproken' tot verschillende elkaar overlappende maar evenzeer ook conflicterende en tegengestelde identiteiten. En zelfs als zij zich volledig zouden identificeren met hun etnische groep, dan zijn er altijd nog partijprogramma's, collegeakkoorden, de fractiediscipline, gelegenheidscoalities en strijd met andere fracties die deze identificatie beperken. Daarom staan raadsleden op onafhankelijkheid ten opzichte van hun etnische groep. Zelfs wanneer zij door personen of organisaties uit hun etnische groep worden benaderd met verzoeken om hulp. Waar nodig zullen zij helpen, maar ze zullen geen speciale gunsten verlenen, omdat ze tot een bepaalde etnische groep behoren:

Alsof ik voor alle Surinaamse zaken zou moeten gaan. Het gaat om de aard van de kwestie en niet of het Surinaams is. Uiteraard omdat ik Srananman (Surinamer) ben en vanuit een primair Surinaamse organisatie werk, ligt me dat na aan het hart. Maar dat leidt er niet toe dat ik per definitie ten opzichte van alles wat Surinaams is loyaal moet zijn.

\section{Kritiek en weerstand}

Maar niet iedereen is het daarmee eens. Raadsleden van allochtone afkomst willen nog wel eens stigma's als verrader, token en bounty opgeplakt krijgen als zij weigeren zich speciaal in te spannen voor leden van hun etnische groep. Illustratief hiervoor is de scheldpartij die Hannah Belliot (tijdens haar voorzitterschap van het dagelijks bestuur van de Deelraad Zuid-Oost) over zich heen kreeg toen zij een groep Surinaamse intellectuelen meedeelde dat zij een bestuursakkoord had uit te voeren. De journalist Gerard van Westerloo tekende het volgende op: 'Schande! Schandelijk! Geen woorden voor!'; 'Dat noemt zich een zwarte vrouw!'; 'Is dit haar bijdrage aan de emancipatie van zwarten?'; 'Nu blijkt hoe wit zij is van binnen.' (zie Westerloo, 2002).

De raadsleden beklemtonen zowel tegenover hun collega's van autochtone afkomst als tegenover leden uit hun etnische groep dat zij in de eerste plaats gekozen zijn voor alle burgers van hun stad. Ze dienen het algemeen belang in de ver- 
schillende commissies waar zij lid van zijn, en dus ook in de commissie diversiteitbeleid:

Ik heb mij altijd geprofileerd als Hagenaar, althans als raadslid voor de hele stad. De overweging die daaraan ten grondslag lag was dat je met elkaar bezig bent een samenleving te formeren uit diversiteit, mensen met allerlei waarden en normen, aspiraties en ideeën. Juist als je uit die groep afkomstig bent, moet je niet gaan fragmenteren door te zeggen: 'Ik wil alleen maar optreden voor die groep.' Die tweespalt langs etnische lijnen moest er niet in komen. Je moet laten zien dat je er voor iedereen bent in de stad. Om dan aan autochtonen duidelijk te maken dat minderheden ook voor hen van betekenis kunnen zijn. Dus ik heb toen ook gezegd dat ik niet alleen op het hoofdstuk minderheden wil worden aangesproken. En ik wil in de raad ook niet alleen dat onderdeel van de politiek bedrijven. Dat wilde dus niet zeggen dat ik niet voor die doelgroep wilde opkomen. Het was meer een soort politiek-strategische invalshoek van waaruit ik dat wilde bekijken. Dat heeft er in geresulteerd dat ik lid werd van verschillende commissies zoals volkshuisvesting, onderwijs, maar ook de commissie minderheden. Later nam ik ook financiën en stadsvernieuwing om te laten zien dat de inzet er was voor alle Hagenaars.

En zelfs als zij vinden dat voorkeurstemmen van een bepaalde groep kiezers een verplichting scheppen tegenover die groep, dan nog hechten zij eraan, zoals de heer C., te benadrukken dat zij eerst het algemeen belang voor ogen hebben:

Nou kijk, je wordt natuurlijk gekozen voor het algemeen belang. Dat staat voorop. Maar we kunnen ook niet om de realiteit heen, en dat is dus dat zoveel mensen op mij een voorkeurstem hebben uitgebracht. Ik vind dat er een beleid moet komen waarin die mensen [migranten] zich herkennen. Ik wilde gewoon, ook vanuit mijn eigen achtergrond, dicht bij het beleid zitten waar het eigenlijk om zou gaan met die groepen. En omdat de wethouder toen al gezegd had, voor de verkiezingen, dat hij met een nieuw beleid zou komen. Nou toen dacht ik, dit moet ik absoluut zelf doen.

De toetreding van allochtone raadsleden roept ook andere weerstanden op. Binnen het CDA bijvoorbeeld ervaart men soms de binnenkomst van Hindoestaanse en islamitische raadsleden als een bedreiging voor de christelijke identiteit van het CDA en de natie, waartegen georganiseerd opgetreden moet worden. In andere partijen, zoals de PvdA, heeft men wel de neiging de emancipatie van allochtone raadsleden in het politiek-bestuurlijke veld te zien als het object en product van emancipatiebeleid en niet als het werk van allochtone actoren zelf. Sommige allochtone raadsleden zien deze problemen als typisch voor het emancipatieproces en voelen zich daarin pioniers, enigszins vergelijkbaar met de eerste vrouwen die in de gemeenteraden kwamen. 


\section{Uitstroom}

Een van onze veronderstellingen is dat gemeenteraadsleden tijdens hun zittingsperiode sociaal kapitaal weten op te bouwen. Contacten met hun colleges en gemeentelijke ambtenaren bieden sommigen de mogelijkheid om te stijgen ten opzichte van de functies die ze voor hun lidmaatschap bekleedden. Van de gemeenteraadsleden van wie dit gegeven toepasbaar of bekend is (210), geldt die stijging voor ongeveer zestig procent van hen. De vraag is of allochtone en autochtone gemeenteraadsleden daarin verschillen. Allochtone raadsleden stijgen iets vaker dan autochtone (73 respectievelijk 65 procent) maar het gaat slechts om een derde van alle allochtone raadsleden.

De aard van de functies na het verlaten van de raad biedt een ander inzicht in de verschillen tussen allochtone en autochtone raadsleden. Gezien het kleine aantal allochtone raadsleden (11) van wie dat bekend is, bieden de gegevens slechts een impressie. Voor beide groepen is het zelf oprichten of toetreden tot een consultancybureau een aantrekkelijk optie (20 procent), hoewel betwijfeld kan worden of dit altijd zulke florerende bedrijfjes zijn. Het meest opvallende is echter de keuze voor politieke of bestuurlijke functies. Allochtone raadsleden kiezen naar verhouding vaker voor een vervolg in de politiek dan autochtone raadsleden (27 respectievelijk 13 procent). Bij bestuurlijke functies liggen de verhoudingen net omgekeerd: bij allochtone raadsleden kiest 27 procent voor een dergelijke functie, bij de autochtone doet 41 procent dat.

\section{Conclusie}

Het heeft er veel van weg dat politici van allochtone afkomst in een 'onmogelijke' situatie moeten proberen om hun politieke 'idealen' waar te maken. Als gevolg van de verruiming van de politieke gelegenheidsstructuur hebben zij gemakkelijker toegang gekregen tot het politieke domein. Raadsleden van allochtone afkomst die verkiesbaar zijn voor een tweede termijn, zijn betrokken bij de formulering van het verkiezingsprogramma en hebben indirect invloed op de onderhandelingen over een collegeakkoord. Maar het is veel moeilijker om de verruiming van de politieke gelegenheidsstructuur te gebruiken voor rechtstreekse interventies ten gunste van de leden van hun etnische groep. Terwijl de meeste van hun autochtone collega's lijken te verwachten dat zij op grond van hun etnische afkomst niet anders kunnen dan zich als Antilliaan, Marokkaan, Surinamer of Turk opstellen (wat ertoe leidt dat ze nauwgezet in de gaten worden gehouden), wordt vanuit deze etnische groepen vaak aangenomen dat zij zich 'natuurlijk' voor hen zullen inspannen (wat ertoe leidt dat ze nauwgezet in de gaten worden gehouden).

Beide kanten lijken hetzelfde wereldbeeld te delen als het om politici van allochtone afkomst gaat, namelijk dat behoren tot een bepaalde etnische groep tegelijkertijd handelen in het belang van die groep inhoudt. Dat is op zich niet zo verwonderlijk. Het heeft alles te maken met de manier waarop politieke partijen en kandidaten van allochtone afkomst van de verruiming van de politieke gelegen- 
heidsstructuur gebruik hebben willen maken. Sommigen hebben tijdens de rekrutering en de aanloop naar de verkiezingen de etnische afkomst te veel op de voorgrond gesteld, omdat zij hoopten nieuwe kiezers te trekken en bepaalde politieke en 124 sociale doelen te realiseren. Zelfs zij die zich niet wensten te profileren op grond van hun etnische afkomst, konden hier niet aan ontsnappen. Het heeft er alleen maar toe geleid dat zij in de eerste plaats als vertegenwoordigers van bepaalde bevolkingsgroepen (allochtone politici) worden gezien in plaats van als volwaardige politici (politici van allochtone afkomst) die de belangen van alle burgers willen behartigen, en alleen soms die van een bepaalde etnische groep.

Allochtone en autochtone gemeenteraadsleden verschillen in enkele algemene demografische achtergrondkenmerken opvallend weinig van elkaar. In hun rekrutering is kennelijk gekozen voor personen die tot dezelfde 'soort' mensen behoren als de Nederlandse raadsleden: overwegend mannelijk en over het algemeen goed opgeleid. Wel zijn de bestuurlijke en politieke netwerken die ze meebrengen qua aard en omvang verschillend. Velen zijn echter juist op die andersoortige netwerken, die vaak te maken hebben met allochtone (hulp)organisaties, uitgekozen en op die manier behoren ze toch weer wel tot dezelfde groep van professionele politici die in Nederland de meerderheid vormen bij alle vertegenwoordigende lichamen. Dat neemt niet weg dat allochtone raadsleden soms worstelen om een balans te vinden tussen het behartigen van specifieke belangen van de etnische groep waaruit ze afkomstig zijn en het universalisme van de politieke ideologie van de partij waartoe ze behoren.

Een fenomeen dat bij verkiezingen is ontstaan, is dat van de voor zichzelf lobbyende kandidaat. Dat kan gezien worden als een uiting van de algemene individualisering in de samenleving. Ook allochtone kandidaten doen daaraan mee waardoor sommigen op voorkeurstemmen alsnog worden gekozen. De eigen gemeenschap werkt daar soms zichtbaar aan mee, zoals een Marokkaanse bakker die een affiche ophangt voor een Marokkaanse kandidaat. Een hechte organisatie van de allochtone gemeenschap heeft voor de allochtone kandidaat waarschijnlijk een groter voordeel dan de contacten waarover een autochtone kandidaat kan beschikken (Fennema, 2003; Fennema \& Tilly, t.v.).

Waarom wil iemand lid van een gemeenteraad worden? De vraag is niet eenvoudig te beantwoorden omdat eigenlijk niet goed duidelijk is wat het 'voordeel' zou zijn, los van politieke of ideologische overwegingen. Voor de negentiende-eeuwer was het antwoord waarschijnlijk nog eenvoudig te geven: burgerplicht, maar ook het behartigen van de belangen van de eigen groep. Aan het begin van twintigste eeuw hadden arbeiders of vakbondsmannen ook een goede reden: het behartigen van de belangen van de arbeidersklasse op lokaal niveau, voor weer anderen stond het vertegenwoordigen van de ideologie van de partij centraal. In het verleden was het zeker zo dat voor sommige raadsleden het toetreden tot de gemeenteraad een eerste stap in de politieke carrière betekende. Degenen die succes hadden op lokaal niveau konden immers dikwijls rekenen op een zetel in de Tweede Kamer, op een burgermeesterschap en een enkeling werd zelfs minister. Anderen bleven politici op 
lokaal niveau maar konden uiteindelijk wethouder worden - zeker in de grote steden een positie met aanzien en met het voordeel van een respectabel inkomen. $\mathrm{Nu}$ ligt dat veel minder duidelijk.

Niettemin denken we dat met deze nadruk op een politieke toekomst andere voordelen over het hoofd worden gezien, namelijk het verwerven van nuttig sociaal kapitaal onder andere uitgedrukt in contacten met ambtelijke beleidsmakers. Allochtone raadsleden worden zichtbaar in het politieke en sociale stedelijke leven en ook voor hen biedt het lidmaatschap de mogelijkheid om sociaal kapitaal, via collega's en ambtenaren, te verwerven voor toekomstig gebruik. Dat oud-raadsleden dat zelf ook zo zien blijkt wel uit het feit dat menigeen na het verlaten van de raad zich richt op de wereld van de consultancy, hoewel niet duidelijk is of dat altijd zo'n groot succes is.

Maatschappelijk gezien is het toetreden van allochtone gemeenteraadsleden van groot belang, maar het wordt door anderen niet altijd evenveel gewaardeerd. Maar door het toetreden wordt het proces van inburgering verstevigd, hebben deze raadsleden een functie als rolmodel en krijgen specifieke problemen van hun gemeenschap een stem. Op dezelfde wijze ging dat met leden uit de arbeidersbeweging en met vrouwelijke raadsleden die vrouwen een grotere stem in de politiek gaven. Maar partijen moeten deze raadsleden ook een zekere vrijheid geven om ze hun eigen rol te laten uitwerken.

Bij de langetermijnontwikkelingen in de samenstelling van gemeenteraden zien we een voortdurend proces van toetreding en terugdringing. De migratie naar Nederland van nieuwe groepen is het gevolg van grote transnationale ontwikkelingen die op dit moment zichtbaar beginnen te worden op lokaal niveau. De komst van allochtone raadsleden heeft zonder enige twijfel de politieke ambities van sommige jonge, mannelijke Nederlandse kandidaten op lokaal niveau geblokkeerd. Maar deze terugdringing verloopt erg geleidelijk en wisselvallig want de uitval onder allochtone raadsleden is aanzienlijk en leidt tot teleurstelling bij raadsleden en partijbestuur. De entree van allochtone raadsleden is daarmee slechts de nieuwste ontwikkeling in een proces dat al honderdvijftig jaar aan de gang is.

\section{Noten}

1. Een eerdere versie van dit artikel is als paper gepresenteerd in de sessie Elites, Marktdag Sociologie, Nijmegen 22 mei 2003. Dit onderzoek maakt deel uit van een door NWO gefinancierd onderzoeksproject getiteld 'Politiek-bestuurlijke elitevorming bij allochtonen' (NWO-dossier 261-98-513).

2. Deze passage is afkomstig uit een van de interviews met vertegenwoordigers van een van de grote partijen die in hun gemeente verantwoordelijk waren voor de samenstelling van de kandidatenlijst voor de gemeenteraadsverkiezingen van 1998. De interviews zijn ons ter beschikking gesteld door de onderzoeksgroep van het Instituut voor Migratie en Etnische Studies die in opdracht van het Ministerie van Binnenlandse zaken en Koninkrijksrelaties onderzoek heeft verricht naar de politieke participatie van etnische minderheden in vier steden. 


\section{Literatuur}

Baggerman, W. (1994). De zevenhonderd van Rotterdam. Een studie naar de herkomst van gemeenteraadsleden 1851-1994. Rotterdam: Gemeente Rotterdam.

Berger, M., Fennema, M., Heelsum, A. van, Tillie, J. \& Wolff, R. (2001). Politieke participatie van etnische minderheden in vier steden. Een onderzoek in opdracht van het Ministerie van Binnenlandse Zaken en Koninkrijksrelaties uitgevoerd door het Instituut voor Migratie en Etnische studies van de Universiteit van Amsterdam, Amsterdam.

Bourdieu, P. (1989). Opstellen over smaak, habitus en het veldbegrip. Amsterdam: Van Gennep.

Callahan, M. (1981). The harbor barons. Political and commercial elites and the development of the port of Rotterdam 1824-1892. Princeton: dissertation.

Doorn, M. van (2002). Het leven gaat er een lichten gang. Den Haag in de jaren 1919-1940. Zwolle: Waanders Uitgevers.

Fennema, M. (2003). Over de kwaliteit van politieke elites. De Gids, 167, 790-800.

Fennema, M. \& Tillie, J. (t.v.). Civic communities and multicultural democracy. In S. Rossteutscher (eds.), Social capital: a democratic elixer? London: Routledge.

Hofland, P. (1998). Leden van de Raad. De Amsterdamse Gemeenteraad 1814-1941. Amsterdam: Gemeentearchief.

Hooghiemstra, E. (2003). Trouwen over de grens. Achtergronden van partnerkeuze van Turken en Marokkanen in Nederland. Den Haag: Sociaal Cultureel Planbureau.

Leijenaar, M., Niemöller, K., \& Kooij, A. van der, (1999). Kandidaten gezocht. Politieke partijen en het streven naar grotere diversiteit onder gemeenteraad. Amsterdam: naam uitgever.

Meijnen, W. \& Rupp, J.C.C. (2001). Succesvolle allochtone leerlingen. Apeldoorn/Leuven: Garant.

Norris, P. (1997). Passages to power. Legislative recruitment in advanced democracies. Cambridge: Cambridge University Press.

Petronilla, S. (red.) (2000). Raadsleden met dubbele antenne. Amsterdam: IPP, 2000.

Pitkin, H., (1967). The concept of representation. Berkeley.

Sas, N.C.F. van, Velde, H. te (1998). De eeuw van de grondwet: grondwet en politiek in Nederland, 1798-1917. Deventer: Kluwer.

Schoemaker, J., (1993). Vrouwen in de Haagse gemeenteraad in het Interbellum. Die Haghe, 205-247.

Stokvis, P.R.D. (1987). De wording van modern Den Haag. Zwolle: Waanders.

Westerloo, G. van (2002). De koningin van de Bijlmer, M, maandblad van NRC Handelsblad, 2 februari 2002, 9.

Zizek, S., (1989). The sublime object of ideology. London: Verso. 


\section{Personalia}

Jennifer R. van den Broeke-George is student aan de Afdeling Sociologie en Antropologie, Universiteit van Amsterdam. E-mail: Jennifer.george@student.uva.nl.

Jaap Dronkers (1945) is thans hoogleraar Social Stratification and Inequality aan het European University Institute in San Domenico di Fiesole (FI) in Italië. Adres: European University Institute, Department of Political and Social Sciences, Department of Political and Social Sciences, Via dei Roccettini 9, I-50016 San Domenico di Fiesole, Italy. E-mail: jaap.dronkers@iue.it. Homepage: http://www.iue.it/Personal/Dronkers.

Meindert Fennema is hoogleraar politieke theorie van etnische verhoudingen aan de UvA. Hij schreef zijn dissertatie over internationale netwerken van dubbelfuncties in het bedrijfsleven (1982). Met Henri Baudet publiceerde hij Het Nederlands belang bij Indië (1983). Onlangs publiceerde hij met William K. Carroll een artikel waarin zijn promotieonderzoek werd herhaald (2002). In 1995 publiceerde hij De moderne democratie. Geschiedenis van een politieke theorie. Thans werkt hij samen met Jean Tillie aan een boek over de kwaliteit van de democratie in multiculturele samenlevingen. E-mail: M.Fennema@uva.nl.

Leny E. de Groot-van Leeuwen is universitair hoofddocent aan het Instituut voor Rechtssociologie van de Faculteit der Rechtsgeleerdheid van de Katholieke Universiteit Nijmegen.

Eelke Heemskerk is politicoloog en thans als promovendus werkzaam bij de Amsterdamse School voor Sociaal Wetenschappelijk Onderzoek. Zijn huidige onderzoek richt zich op sociale netwerken in de top van het Nederlandse bedrijfsleven. 
Joris Nobel is verbonden aan het Centraal Bureau voor de Statistiek. Hij adviseert en publiceert over statistische gegevensbescherming en de wetenschappelijke toegang tot microdata, en over allerlei andere actuele respectievelijk historische institutionele' aspecten van de officiële statistiek. De netwerkanalyse in deze bundel berust op onderzoek buiten het CBS, e-mail: JNBL@CBS.NL.

Jan C.C. Rupp is als gastonderzoeker verbonden aan de Amsterdamse School voor Sociaal Wetenschappelijk Onderzoek van de UvA. Hij publiceerde onder meer: Onderwijs in de tijd (Boekaflevering Mens en Maatschappij, 1992) en Van oude en nieuwe universiteiten (Nederlandse Cultuur in Europese Context dl 8, 1997). Tevens maakt hij deel uit van een ontwikkelgroep voor een kindermuseum in het Herinneringscentrum Kamp Westerbork.

Huibert Schijf is verbonden aan de Faculteit der Maatschappij- en Gedragswetenschappen, Afdeling Sociologie en Antropologie, Universiteit van Amsterdam. Hij is redacteur van Mens en Maatschappij. Hij publiceert over financieel-economische elites, handelsminderheden en joodse bankiers in de negentiende eeuw. E-mail: h.schijf@uva.nl.

John Schuster is werkzaam bij de Afdeling Sociale Geneeskunde van het Academisch Medisch Centrum (UvA). E-mail:J.Schuster@amc.uva.nl. 